Cultural Resources Survey and Evaluation of Archeological Sites 41WS105, 41WS159, 41WS160, and 41WS161 for the Proposed Fence Line Project in Grasslands Units 48, 62 and 63, Lyndon B. Johnson National Grassland, Wise County, Texas

Steve Sarich

Josh Haefner

Follow this and additional works at: https://scholarworks.sfasu.edu/ita

Part of the American Material Culture Commons, Archaeological Anthropology Commons, Environmental Studies Commons, Other American Studies Commons, Other Arts and Humanities Commons, Other History of Art, Architecture, and Archaeology Commons, and the United States History Commons

Tell us how this article helped you.

This Article is brought to you for free and open access by the Center for Regional Heritage Research at SFA ScholarWorks. It has been accepted for inclusion in Index of Texas Archaeology: Open Access Gray Literature from the Lone Star State by an authorized editor of SFA ScholarWorks. For more information, please contact cdsscholarworks@sfasu.edu. 
Cultural Resources Survey and Evaluation of Archeological Sites 41WS105, 41WS159, 41WS160, and 41WS161 for the Proposed Fence Line Project in Grasslands Units 48, 62 and 63, Lyndon B. Johnson National Grassland, Wise County, Texas

Creative Commons License

(c) (i) (2)

This work is licensed under a Creative Commons Attribution-NonCommercial 4.0 International License 


\section{Cultural Resources Survey and Evaluation of Archeological Sites 41WS105, 41WS159, 41WS160, and 41WS161 for the Proposed Fence Line Project in Grasslands Units 48, 62 and 63, Lyndon B. Johnson National Grassland, Wise County, Texas}

By:

Steve Sarich and Josh Haefner

Prepared for:

United States Forest Service

National Forests \& Grasslands in Texas

Lufkin, Texas

Forest Service Event ID:

R2020081308003

Prepared by:

TRC Environmental Corporation

Austin, Texas

Josh Haefner, Principal Investigator

TRC Technical Report No. 355649

February 2020 
This page intentionally left blank. 


\section{ABSTRACT}

The United States Forest Service (USFS) is proposing to reconstruct perimeter fencing surrounding three Grasslands units located within the Lyndon B. Johnson National Grassland (LBJ National Grassland) in Wise County, Texas. As part of the proposed perimeter fence reconstruction within the three proposed Grasslands units, the USFS is seeking a general inventory of cultural resources which includes background and historic research, archeological field survey, site delineation, a determination of the condition of recorded cultural resources, and recommendation of eligibility for listing on the National Register of Historic Places (NRHP) of any sites encountered.

The overall project tracts are subject to federal jurisdiction and falls under the regulations of Section 106 of the National Historic Preservation Act (NHPA) of 1966, as amended (U.S. Code 16, §470, et seq.). To ensure compliance with Section 106 of the NHPA, the USFS contracted with TRC Environmental Corporation (TRC) to conduct any necessary field investigations required as determined during the coordination process.

The Area of Potential Effects (APE) consists of three Grasslands units where proposed perimeter fence reconstruction will occur. The three Grasslands units include Unit 48, Unit 62, and Unit 63. Together, the three Grasslands units measure 399 acres. A cultural resources survey of these three Grasslands units was performed under Section 106 of the NHPA. For these investigations, Josh Haefner served as the Principal Investigator and Steve Sarich was the Project Archeologist. Field work was conducted by Josh Haefner, Steve Sarich, Benjamin Johnson, Gregg Cestaro, and Haley Wilkerson, the latter two individuals employed by Hicks \& Company, the small-business subconsultant for this project.

Results of the background review, completed prior to the field investigation determined that one previously recorded site, 41WS105, is located within the APE; no cemeteries or historic structures were noted within the APE; while one previous cultural resources survey has been performed within or within the vicinity of the APE. This previous survey was a limited seismic survey of Unit 48 and resulted in the discovery of $41 \mathrm{WS} 105$.

Prior to survey, TRC coordinated with the USFS on the proposed survey methodology and research design. TRC archeologists performed survey supplemented with shovel testing at the three Grasslands units on October 31- November 08 and December $04-06,2019$. During the investigations, a total of 412 shovel tests were excavated. Of these tests, 405 were negative for cultural materials. In addition to these tests 65 points were recorded as "No Dig" locations due to ground disturbance, slope, or other impediment. Seven shovel tests were positive for cultural materials. Three new sites were recorded within the APE and an extension to previously recorded 41WS105 (forest service number: 08130800055) was delineated as a result of the survey. As shovel testing at two of the new sites, 41WS160 (08130800526) and 41WS161 (08130800527), noted no buried cultural deposits and historic cultural materials were observable on the ground surface, these boundaries were established by the mapping of the horizontal distribution of artifacts along the ground surface. Boundaries for the $41 \mathrm{WS} 105$ and $41 \mathrm{WS} 159$ (08130800525) were based on both the distribution of positive shovel tests and the presence of cultural materials on the ground surface. Based on the results of the cultural resources survey, TRC recommends that no further investigations are necessary and the project may proceed as planned with no historic properties affected. 
This page intentionally left blank 


\section{TABLE OF CONTENTS}

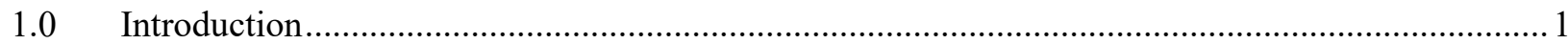

2.0 Physiographic and Environmental Context............................................................................

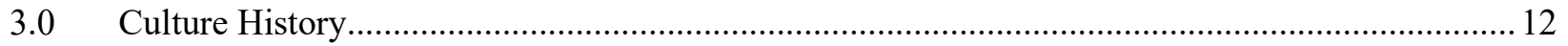

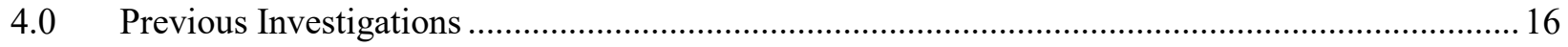

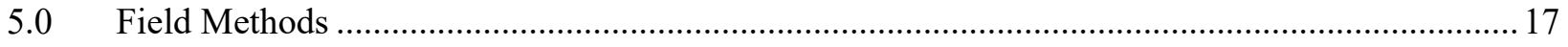

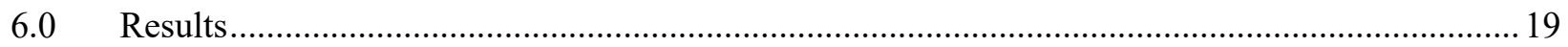

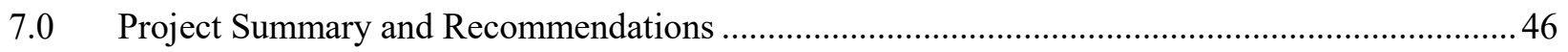

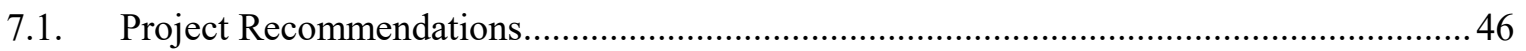

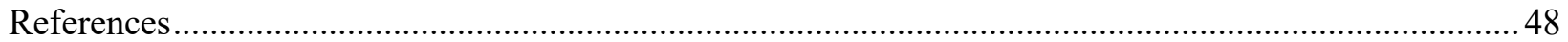

\section{LIST OF FIGURES}

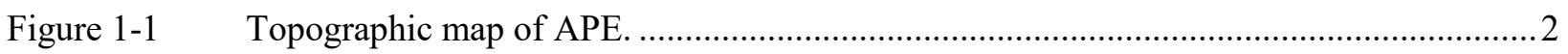

Figure 1-2 Aerial map of APE................................................................................................

Figure 2-1 Project Location within the Oak Woods \& Prairies Physiographic Region of Texas..........6

Figure 2-2 Underlying geology within and adjacent to the LBJ Grasslands APE............................... 8

Figure 2-3 Soils within LBJ Grasslands Unit 48 APE. ..............................................................

Figure 6-1 Overview of vegetation at Unit 48, facing north. ....................................................2

Figure 6-2 Overview of vegetation at Unit 62, facing south. ........................................................20

Figure 6-3 Overview of vegetation at Unit 63, facing southeast.......................................................21

Figure 6-4 Site 41WS105 overviews facing north, east, southwest, and west (left to right)..............23

Figure 6-5 White chert debitage recorded on the surface of 41WS105 Extension.............................24

Figure 6-6 Debitage recorded in shovel test 177 SS at 20-30 cmbs.............................................2

Figure 6-7 Two items of lithic debitage recorded in shovel test 177-SS at 30-40 cmbs....................25

Figure 6-8 Two items of debitage recorded in shovel test 177-SS at 60-70 cmbs. ...........................25

Figure 6-9 Debitage recorded in shovel test 52-JH at 20-30 cmbs.............................................26

Figure 6-10 Debitage recorded in shovel test 63-BJ at 60-70 cmbs...............................................26

Figure 6-11 Overviews of 41WS159, facing north, east, south, and west (left to right)......................28

Figure 6-12 Ironstone, milk glass, and molded glass recorded in 72-SS at 0-10 cmbs......................29

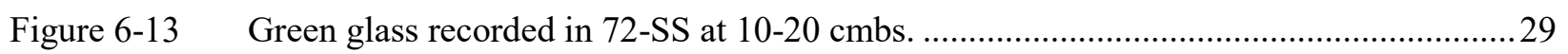

Figure 6-14 Transfer print sherd and plain whiteware sherd recorded in 72-SS at 20-30 cmbs. .........30

Figure 6-15 Undecorated stoneware sherd and milk glass recorded in 99-SS at 0-10 cmbs................30

Figure 6-16 Container glass recorded in 101-SS at 0-10 cmbs. ........................................................

Figure 6-17 Possible cut stone feature near road, facing northwest. ....................................................31 
Figure 6-18 Push pile in sparse wooded area, facing southeast....................................................... 32

Figure 6-19 Overview of site 41WS160, facing north, east, south, and west (left to right)................33

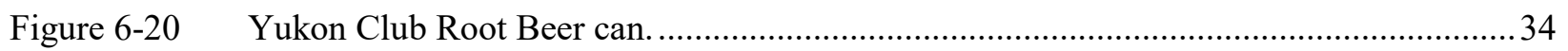

Figure 6-21 Pull top opening common to the sanitary cans found at 41WS160 ...............................34

Figure 6-22 Heavily rusted sanitary can with evidence of bullet holes.............................................35

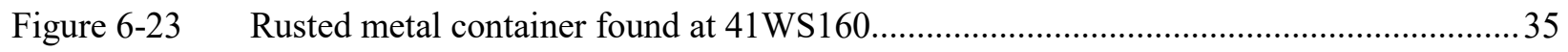

Figure 6-24 Side view of rusted container showing evidence of bullet holes. ....................................36

Figure 6-25 Overview of 41WS161, facing north, east, south, and west (left to right).......................38

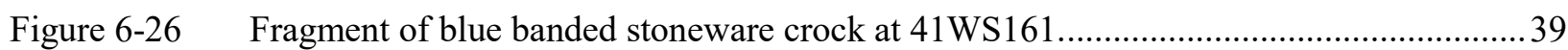

Figure 6-27 Overview of fragmented crock, facing southeast.........................................................39

Figure 6-28 Brick with letters "DEN...FIRE...B" likely produced by Denton Pressed Brick Company.

Figure 6-29 Unknown metal container, facing southeast. ............................................................. 40

Figure 6-30 Evidence of modern materials deposited and intermixed with historic materials.............41

Figure 6-31 Overview of windmill and modern galvanized stock tank, facing northwest..................42

Figure 6-32 Close up of windmill head and blades, facing northwest. ..............................................43

Figure 6-33 Metal piping without output to the stock tank, facing northwest................................43

Figure 6-34 Galvanized steel stock tank, facing southwest.........................................................4

Figure 6-35 Farmaster label on stock tank, facing southeast.........................................................4

\section{LIST OF APPENDICES}

Appendix A: Design Plans and APE

Appendix B: Shovel Test Results

Appendix C: Historical and Archival Research

Appendix D: Survey Results and Site Maps 


\subsection{INTRODUCTION}

The United States Forest Service (USFS) is proposing to reconstruct perimeter fencing surrounding three Grasslands units located within the Lyndon B. Johnson National Grassland (LBJ National Grassland) in Wise County, Texas as implementation of the LBJ Prairie Savanna Restoration Project. This project is necessary to create a 40--foot fireline around LBJ National Grasslands units as these units are overgrown with dense vegetation and have limited to no mobility through them, posing a wildfire hazard. Impacts entail bulldozing to clear these perimeters of all trees and other woody vegetation, both above and below ground and new fence construction including utilization of metal t-posts and the use of an auger to drill into the ground to set metal corner posts and concrete bracing. As part of the proposed perimeter fence reconstruction, the USFS has contracted with TRC Environmental Consultants (TRC) to perform an inventory of cultural resources within three proposed Grasslands units (Units 48, 62, and 63) which includes background and historic research, archeological field survey, site delineation, a determination of the condition of recorded cultural resources, and recommendation of eligibility for listing on the National Register of Historic Places (NRHP), as amended (U.S. Code 16, §470, et seq.).

The Area of Potential Effects (APE) consists of the entirety of three Grasslands unit locations where proposed perimeter fence reconstruction will occur. The three Grasslands units include Unit 48, Unit 62, and Unit 63. Grasslands Unit 48 has an approximate perimeter measurement of 5,272 meters (m) [17,297 feet (ft)] and spans approximately 190 acres (ac). Unit 62 has an approximate perimeter measurement of $1,811 \mathrm{~m}[5,942 \mathrm{ft}]$ and spans approximately $49 \mathrm{ac}$. Unit $63 \mathrm{has}$ an approximate perimeter measurement of 4,035 $\mathrm{m}[13,238 \mathrm{ft}]$ and spans approximately $160 \mathrm{ac}$. The total APE for the three Grasslands units is 399 ac (Figure 1-1 and Figure 1-2). Though impacts from fencing and fireline constructing will likely be limited to a 40-foot corridor around each unit; archeological survey covered the entirety of each Grasslands unit to evaluate and record any cultural resources located within the three boundaries.

Fieldwork was conducted from October 31- November 08 and December $04-06,2019$. The field effort consisted of pedestrian survey supplemented with shovel testing of the APE. Minimally, TRC excavated shovel tests within each of the Grasslands units at $30 \mathrm{~m}$ transect spacing with shovel test intervals no greater than $150 \mathrm{~m}$. In certain instances, this number was increased during site recording to gather additional data on deposition. Hence, a total of 412 shovel tests were excavated during the archeological survey. Of these tests, 405 were negative for cultural materials. In addition to these tests 65 points were recorded as "No Dig" locations due to ground disturbance, slope or other impediment. Seven shovel tests were positive for cultural materials. A total of three new archeological sites were recorded during the current investigations and the site boundaries to previously recorded site $41 \mathrm{WS} 105$ (forest service number: 08130800055) was extended approximately $124 \mathrm{~m}$ to the northwest. As shovel testing at two of the new sites, 41WS160 (08130800526) and 41WS161 (08130800527), noted no buried cultural deposits and historic cultural materials were observable on the ground surface, these boundaries were established by the mapping of the horizontal distribution of artifacts along the ground surface. Extended boundary to 41WS105 and delineation of 41WS159 (08130800525) were based on both the distribution of positive shovel tests and the horizontal distribution of artifacts on the ground surface. This report presents the findings of the cultural resource investigations. 


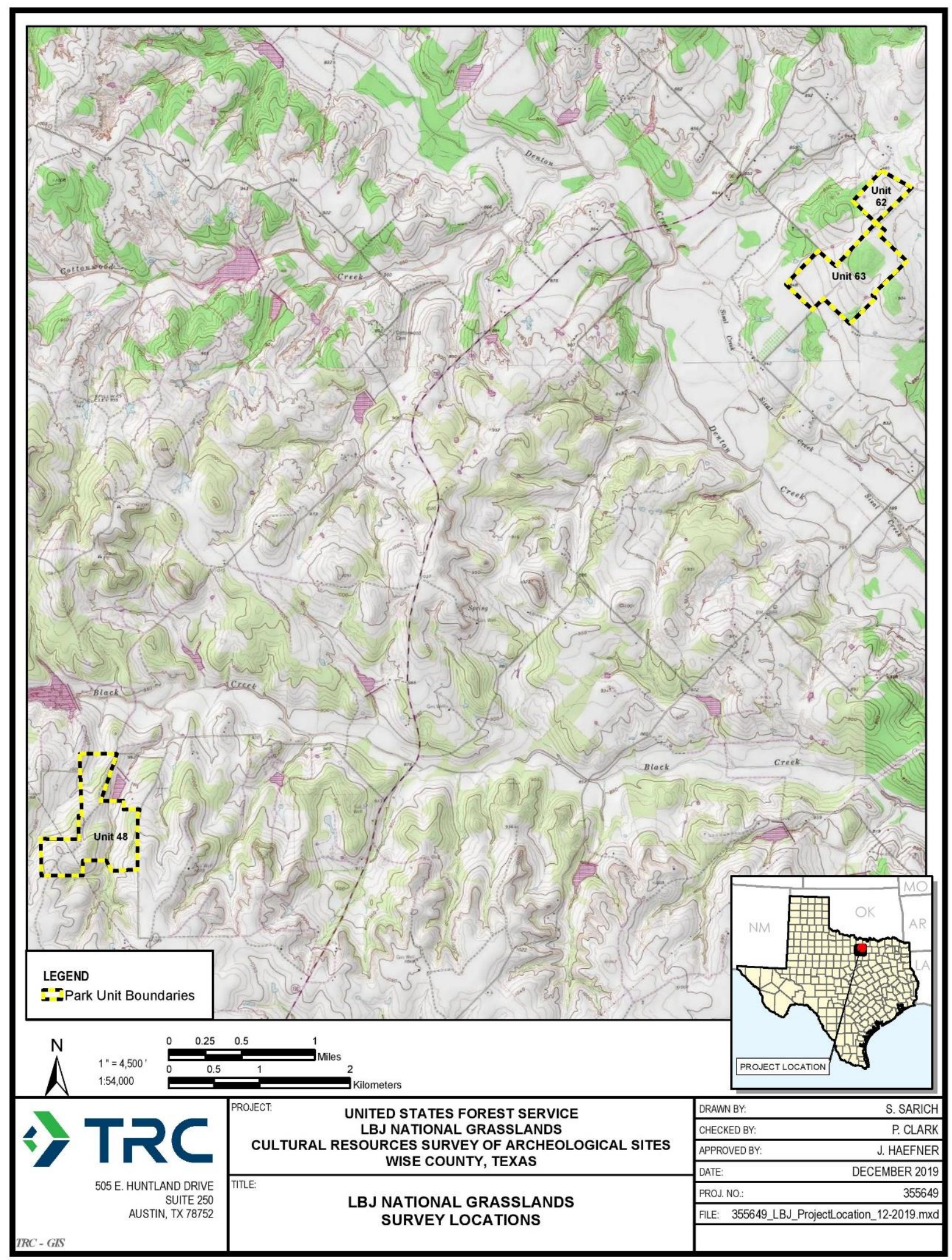

Figure 1-1 Topographic map of APE. 


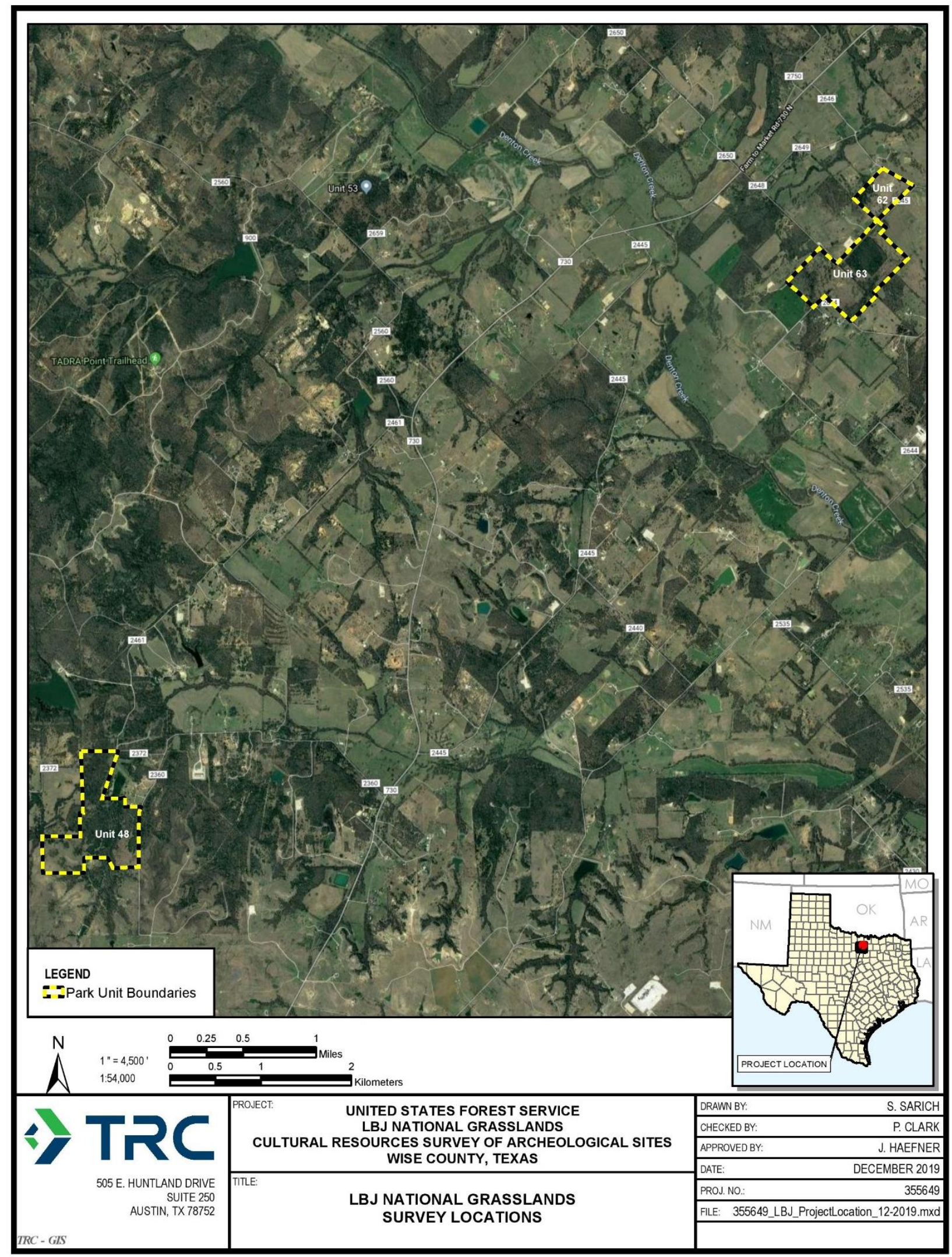

Figure 1-2 Aerial map of APE. 
This page intentionally left blank 


\subsection{PHYSIOGRAPHIC AND ENVIRONMENTAL CONTEXT}

\section{Physiography}

The project area lies within the Oak woods and Prairies physiographic region of Texas, near its interface with the Blackland Prairies to the east (Figure 2-1). To the west, the Cross Timbers and Prairies are bordered by the Rolling Plains. The Oak woods and Prairies region can be further subdivided into four ecological or vegetative sub-regions: the West Cross Timbers, Fort Worth Prairie, Lampasas Cut Plain, and the East Cross Timbers. dominate geologic units of the Cross Timbers and Prairies were formed during the Paleozoic (approximately 30 percent) and Mesozoic eras (70 percent) and the resulting topography is characterized by gently rolling uplands dissected by ephemeral and deeply cut streams.

\section{Flora and Fauna}

The proposed project lies within the Cross Timbers and Prairies Ecological Area of Texas (Gould 1960) and in the Texan Biotic Province (Blair 1950). The Cross Timbers and Prairies Ecological Area is a transitional area between the Great Plains of the central United States and the forested low mountains and hills of eastern Oklahoma and Texas. The region is a mosaic of forest, woodland, savanna, and prairie. The physiognomy of the Cross Timbers is oak wood and tallgrass prairie. Dominant woody species include post oak (Quercus stellata), blackjack oak (Quercus marilandica), eastern red cedar (Juniperus virginiana), bumelia (Bumelia lanuginosa), and greenbrier (Smilax bona-nox). Forbs of the region include bluebonnets (Lupinus texensis), Engelmann daisy (Engelmannia pinnatifida), and Maximillian sunflower (Helianthus maximilliani). Tall and midgrasses are dominant and include such species as big bluestem (Andropogon gerardii), little bluestem (Schizachyrium scoparium), indiangrass (Sorghastrum nutans), and sideoats grama (Bouteloua curtipendula). This region is not well suited for cropland and is mostly used for rangeland and pastureland. Oil production is also a major activity in this region (Gould et al. 1960).

Mammal species typical of the Texan Biotic Province include Virginia Opossum (Didelphis virginiana), Eastern Mole (Scalopus aquaticus), Fox Squirrel (Sciurus niger), Fulvous Harvest Mouse (Reithrodontomys fulvescens), Hispid Cotton Rat (Sigmodon hispidus), Deer Mouse (Peromyscus maniculatus), Eastern Cottontail (Sylvilagus floridanus), Swamp Rabbit (Sylvilagus aquaticus), and Blacktailed Jackrabbit (Lepus californicus). Reptiles of the province include Ornate Box Turtle (Terrapene ornata), Eastern Box Turtle (Terrapene carolina), Green Anole (Anolis carolinensis), Fence Lizard (Sceloporus undulatus), Eastern Racer (Coluber constrictor), Coachwhip (Masticophus flagellum), Eastern Rat Snake (Elaphe obsoleta), Common Kingsnake (Lampropeltis getula), Cottonmouth (Agkistrodon piscivorus), and Western Diamondback Rattlesnake (Crotalus atrox). Typical anuran species include Hurter's Spadefoot Toad (Scaphiopus hurterii), Gulf Coast Toad (Bufo valliceps), Woodhouse's Toad (Bufo woodhousii), Northern Cricket Frog (Acris crepitans), Strecker's Chorus Frog (Pseudacris streckeri), Gray Treefrog (Hyla versicolor), Green Treefrog (Hyla cinerea), Bullfrog (Rana catesbiana), and Rio Grande Leopard Frog (Rana berlandieri) (Blair 1950). 


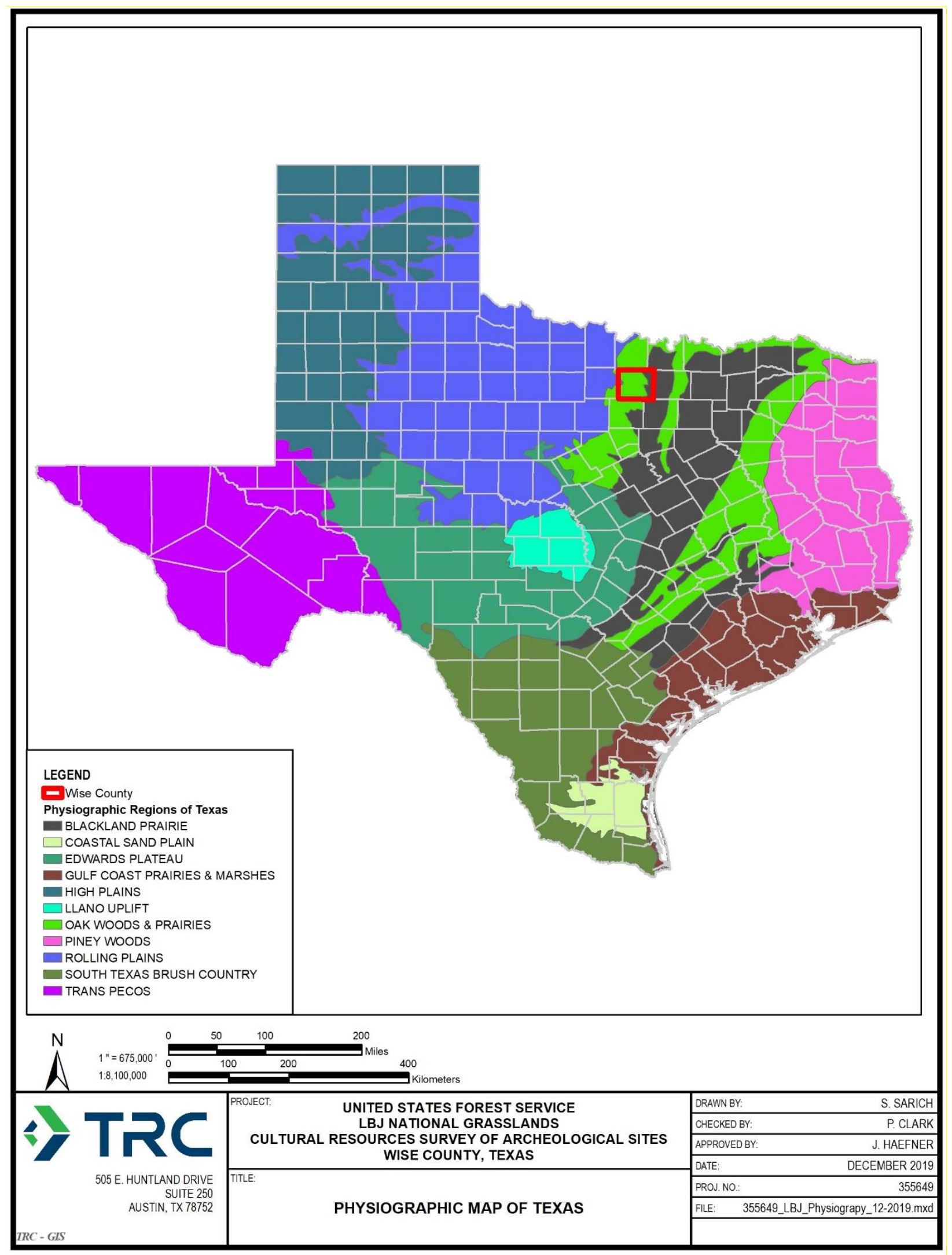

Figure 2-1 Project Location within the Oak Woods \& Prairies Physiographic Region of Texas. 
The underlying geology of Units 62, 63, and the majority of Unit 48 consists of Early Cretaceous Antlers Sand (Ka). The 1991 Geologic Atlas of Texas, Sherman Sheet notes that Antlers Sand is commonly found in the eastern part of the Trans-Pecos and High Plains and consists of sand, clay, and conglomerate. Lower and upper parts are mostly sand, the middle part chiefly clay, and grades northward to interbedded sand and clay. Sand is typically fine to coarse grained, conglomeratic in the lower parts, clayey in the upper parts. Conglomerate is mixed with chert, quartz, and quartzite as pebbles and granules. The thickness of Antlers Sand ranges between 500-650 ft. Sandstone, claystone, and conglomerate ranges in thickness as much as $200 \mathrm{ft}$, but is variable because of the irregular surface on which it was deposited. The underlying geology of the southern portion of Unit 48 also consists of Early Cretaceous Goodland Limestone and Walnut Clay, undivided (Kgw). According to the Geologic Atlas the formation is predominantly fine-grained Goodland Limestone which becomes more nodular toward the base. The formation grades downward to Walnut Clay, interbedded coquinite, and dark-gray, marly shale. The thickness of Goodland Limestone and Walnut Clay, undivided in Texas ranges from 13-20 ft. (Figure 2-2).

According to the U.S. Department of Agriculture (USDA) Web Soil Survey (2015), the soils present within Unit 48 consist of Brackett-Aledo complex with 5 to 10 percent slopes (ByE), Duffau loamy fine sand with 1 to 5 percent slopes (DfC), Frio silty clay loam, occasionally flooded (Fr), Keeter very fine sandy loam with 1 to 6 percent slopes (KtC), Keeter very fine sandy loam with 2 to 6 percent slopes, severely eroded (KtC3), Patilo-Heaton fine sands with 3 to 12 percent slopes (PhC), Pulexas soils, frequently flooded $(\mathrm{Pu})$, Somervell-Aledo complex with 1 to 8 percent slopes (SoC), Venus loam with 3 to 8 percent slopes (VeC), Water (W), Duffau-Windthorst complex with 1 to 5 percent slopes, moderately eroded (WeC), Weatherford-Duffau complex with 2 to 8 percent slopes, severely eroded (WeC3), and Duffau-Weatherford complex with 3 to 8 percent slopes (WeD) (Figure 2-3).

The soils present within Unit 62 consist of Bastsil fine sandy loam with 0 to 3 percent slopes (BfB), Duffau loamy fine sand with 1 to 5 percent slopes (DfC), Keeter very fine sandy loam with 1 to 6 percent slopes (KtC), Somervell-Aledo complex with 1 to 8 percent slopes (SoC), Speck clay loam with 0 to 2 percent slopes ( $\mathrm{SpB}$ ), Venus loam with 3 to 8 percent slopes $(\mathrm{VeC})$, and Weatherford-Duffau complex with 2 to 8 percent slopes, severely eroded ( $\mathrm{WeC} 3)$.

The soils present within Unit 63 consist of Bastsil loamy fine sand with 0 to 3 percent slopes (BdB), Bastsil fine sandy loam with 0 to 3 percent slopes (BfB), Duffau loamy fine sand with 1 to 5 percent slopes (DfC), Hassee fine sandy loam with 0 to 2 percent slopes $(\mathrm{HaB})$, Keeter very fine sandy loam with 1 to 6 percent slopes (KtC), and Weatherford-Duffau complex with 2 to 8 percent slopes, severely eroded (WeC3) (Figure 2-4). 


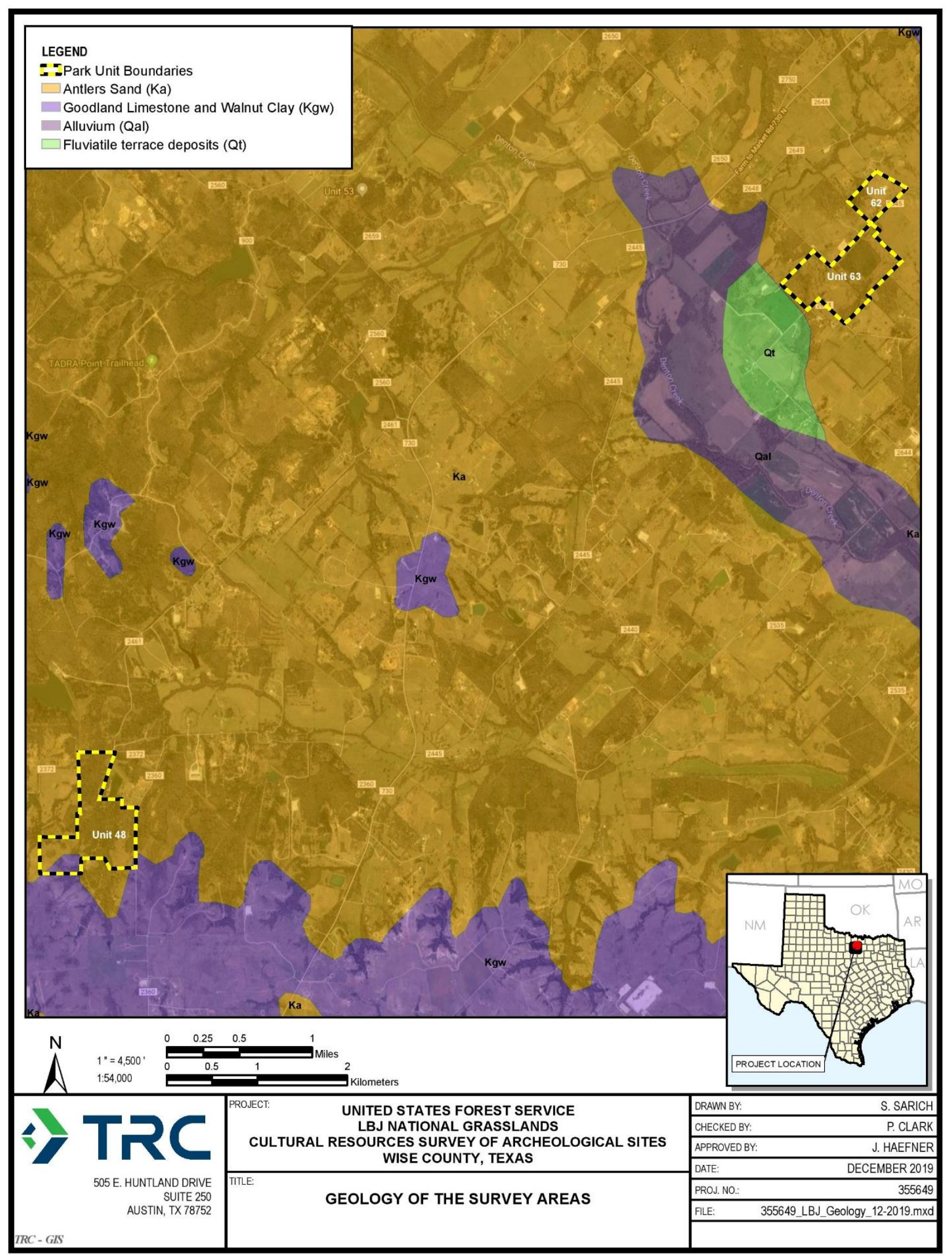

Figure 2-2 Underlying geology within and adjacent to the LBJ Grasslands APE. 


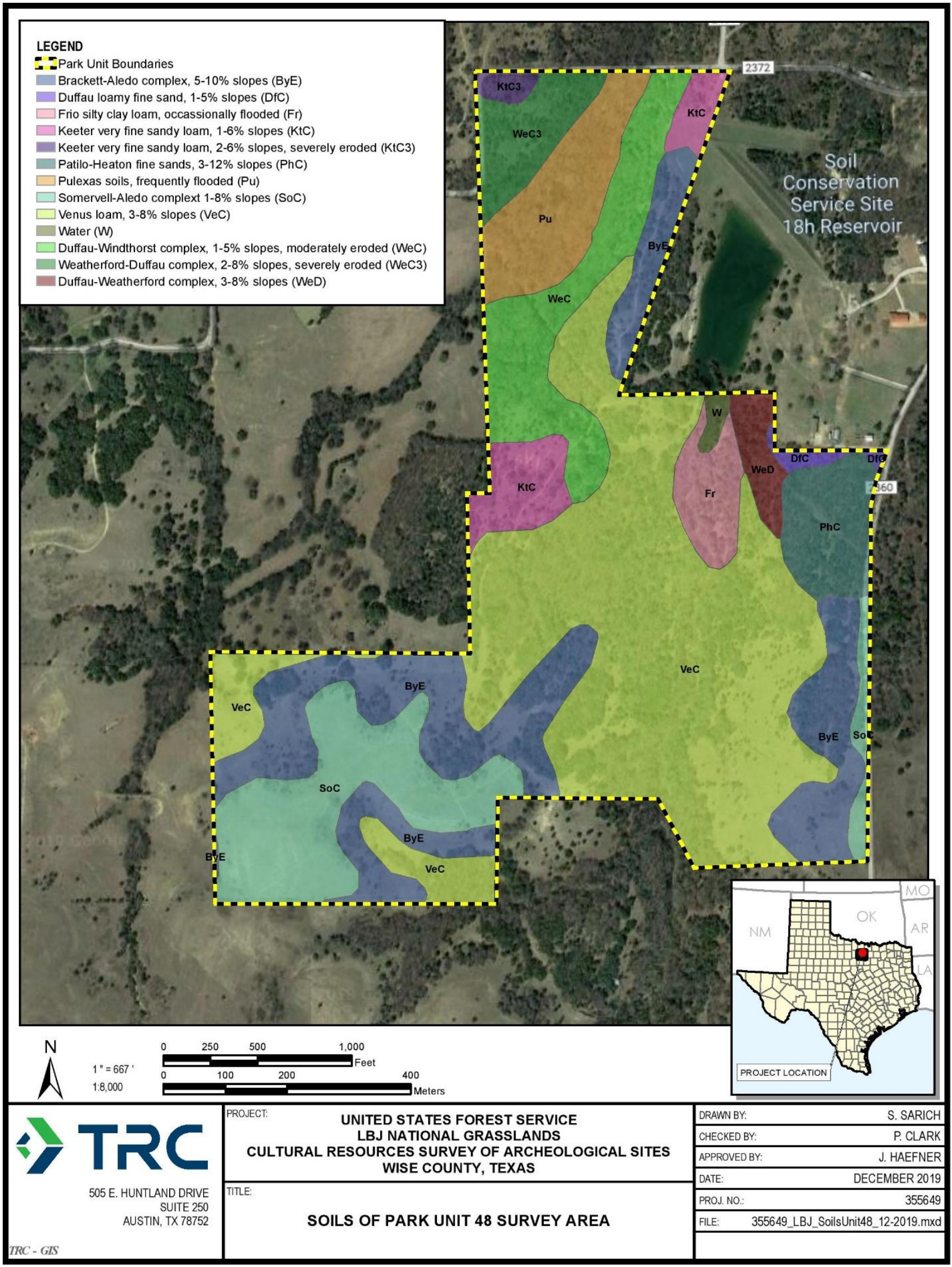

Figure 2-3 Soils within LBJ Grasslands Unit 48 APE. 


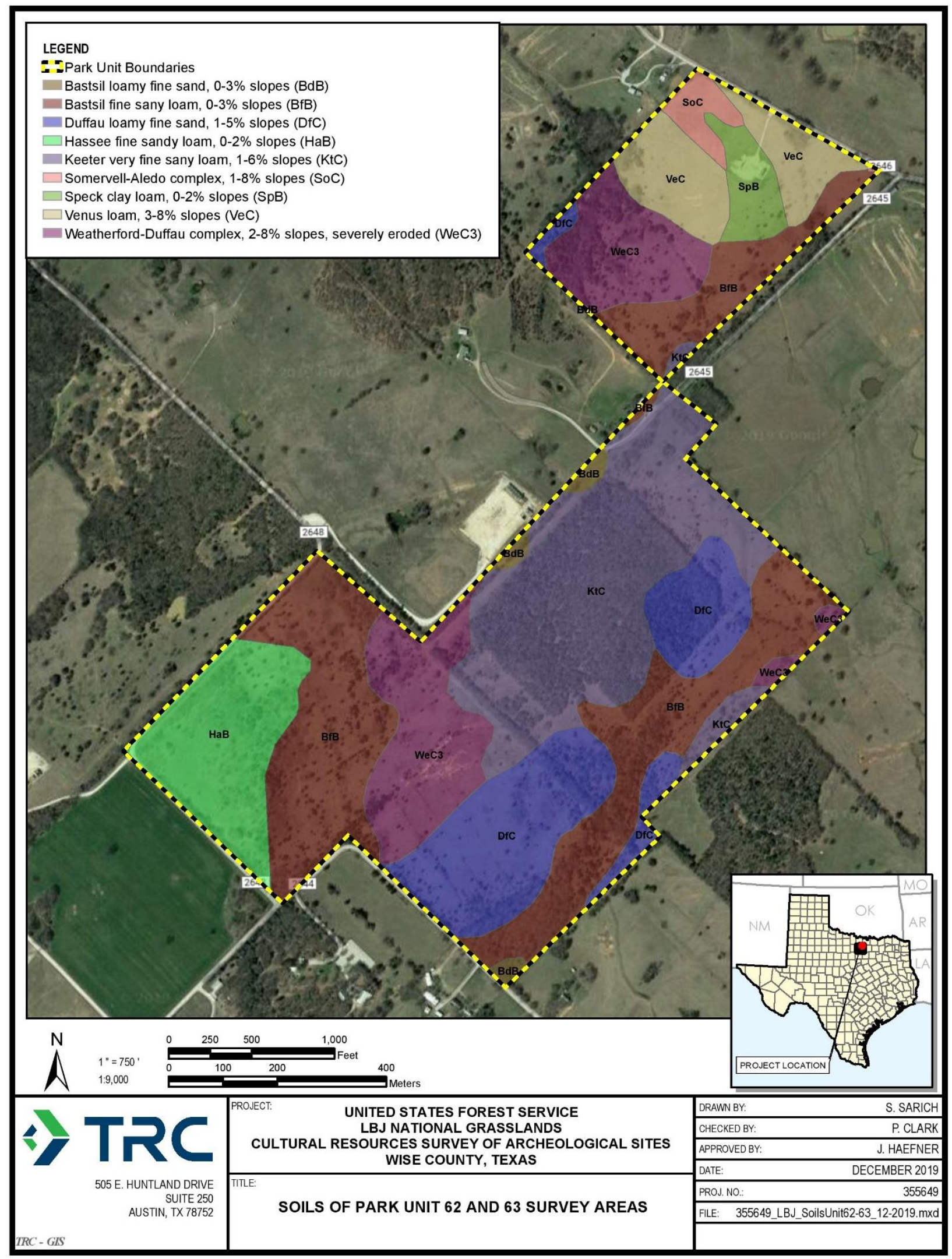

Figure 2-4 Soils within LBJ Grasslands Unit 62 and Unit 63 APE. 
Cultural Resources Survey and Evaluation of Archeological Sites 41WS105, 41WS159, 41WS160, and 41WS161 for the Proposed Fence Line Project in Grasslands Units 48, 62, and 63, LBJ National Grassland, Wise County, Texas

This page intentionally left blank. 


\subsection{CULTURE HISTORY}

\section{Cultural Background}

The project area lies within the northeastern reach of the North-Central Texas culture area as defined by Suhm et al. (1962). Other scholars who have contributed to this region's chronological framework include Krieger (1946); Prewitt (1981); Prikryl 1990; and Vehik (1994). Generally, the cultural chronology of the area follows that proposed by Prikryl (1990): Paleoindian (pre 8500 before present), Early Archaic (85006000 B.P.), Middle Archaic (6000-3500 B.P.), Late Archaic (3500-1250 B.P.), Late Prehistoric I (1250750 B.P.), and Late Prehistoric II (750-250 B.P.).

\section{Paleoindian (ca. 11000-8500 BP)}

While there is considerable evidence for a Paleoindian presence in the North-Central Texas area, most of this evidence comes in the form of mixed artifact assemblages and finds in surface contexts, limiting the information that can be extracted for this time period (Meltzer 1987). Early Paleoindian Clovis and Plainview points are reported with good frequency from Eastern Cross Timbers region northwest of Dallas, patterning in proximity to Denton and Clear creeks (Peter and Harrison 2011:21)

The oldest dated site within the North-Central Texas region, with a highly suspect age of 37 B.P., is the Lewisville Site. While claims that the site's many hearth features were excavated in situ may be accurate, critiques cite lack of diagnostic artifacts $(n=1)$ and erroneous radiocarbon dating due to lignite contamination as valid reasons to question claims to the site's antiquity (Stanford 1981). Investigations at the Aubrey Clovis Site (Ferring 1989a, 1989b, 1990, 1995), located north of Lake Lewisville west of Elm Fork, has contributed a significant amount to what is known of regional Clovis occupations. The site is approximately seven to eight meters below the top of the Elm Fork floodplain. While the Lewisville Site assemblage consisted of more than a handful of artifacts, recovered tool and debitage samples at Aubrey number over 10,000 (Ferring 1989a). All of the lithic materials at the Aubrey Site are non-local and indicative of long-distance trade and analysis of this assemblage indicates that a curated technological organization coupled with intensive tool utilization was practiced (Ferring 1989a, 1989b). Faunal analysis suggests that there was variable exploitation of small, medium and large game including bison, deer, rabbit, squirrel, fish and turtle. Additionally, mammoth remains have been unearthed at Aubrey, although it is not clear if these animals are associated with subsistence practices. With deposits approaching eight meters below ground surface, this site is an indicator of the elusiveness of intact sites dating to this period.

Projectile points of Plainview and Dalton varieties occur with the most frequency (Prikryl 1990), and their association suggests that the area was a borderland where Plainview occupations from the Rolling and High Plains interfaced with the Dalton culture from areas located to the east (Johnson 1987). Due to mixed contexts, site dating has been done by cross referencing projectile points with same types from other, more controlled, sites. Cross dating of the Plainview and Dalton varieties date Paleoindian occupations to ca. 9.5-10 B.P. (Ferring and Yates 1997:5). Peter and Harrison (2011:21) note that these dates may correlate with the advent of early Holocene alluviation within the Trinity River Valley area. 


\section{Early Archaic (ca. 8500-6000 B.P.)}

The vast majority of Early Archaic sites in the region are surface sites recorded in the Trinity River Basin and are recognized by the presence of Angostura, Early Split Stemmed, and Kirk projectile points, as well as, Clear Fork gouges (Byers 2007; Story 1990). In situ sites currently on record are limited to Lake Lewisville, which has an Early Archaic component as well as Paleoindian and Middle Archaic components (Ferring and Yates 1997). Early Archaic components have been recovered during excavations at the Aubrey Clovis Site; Ferring (1989a), however, has questioned their context.

With little in the way of isolatable sites in the region, Early Archaic lifeways are hard to define for NorthCentral Texas. Generally, it is hypothesized that diffused hunting and gathering subsistence economies were practiced (Prikryl 1990; Ferring and Yates 1997). Small-sized and widely distributed sites indicate high mobility.

\section{Middle Archaic (6,000-3,500 B.P.)}

In comparison with the Early Archaic, there are far less recorded Middle Archaic components for the NorthCentral Texas region. The Calvert Site (41DN102) at Lake Ray Roberts is the only known buried in situ site that has a definitive association with the Middle Archaic period (Byers 2007). Associated with this site were a rock-filled hearth, a flexed burial of an adult male and an unmixed assemblage of fauna and artifacts. Projectile points associated regionally with the Middle Archaic are Bulverde, Frio, Trinity, Carrolton, Wells and the basal-notched Bell and Calf Creek types. These points are often used to date surface sites (Prikryl 1990; Story 1990). Prikryl (1990:71-74) notes that within the middle Elm Fork Trinity Valley there is a noticeable paucity in Middle Archaic sites when compared to other time periods. Prikryl (1990) attributes this to the altithermal, while Ferring and Yates (1997) note that in addition to dry climate and associated reduced occupation potential, existing sites may be deeply buried.

\section{Late Archaic (3500-1250 B.P.)}

In stark contrast to the Middle Archaic, sites dating to the Late Archaic are - by far the most common in the archaeological record\| for North-Central Texas (Ferring and Yates 1997: 6). Prikryl (1990) notes that regional surface collections contain between two to three times the amount of Late Archaic point types than points from other archeological periods. When compared to the Middle Archaic, the ratio increases to just over 60:1 (Prikryl 1990: 52-53).

While Ferring and Yates (1997) note that regional buried Late Archaic sites are generally shallow and easily detected, they offer that this alone cannot account for their numbers in the archeological record and posit an increase in population density. Story (1981) offers that this population increase is the result of a shift in exploitation strategies, reduced mobility and a climate shift back to more mesic conditions.

\section{Late Prehistoric I (1250-750 B.P)}

During the Late Prehistoric I period, new technologies included the bow and the arrow and ceramics. The intermittent introduction of these technologies suggests a gradual, non-abrupt transition from the Archaic to the Late Prehistoric. Prikryl (1990) notes that characteristic projectile points such as Scallorn, Steiner, and Catahoula varieties were more commonly fashioned from quartzite during the early stages of the Late 
Prehistoric I. During the latter half of the Late Prehistoric I, there is an increase in the use of chert as a raw material for these point types. A brief xeric episode is posited for approximately 1000 B.P., and differing sources for these projectile points may be tied to adaptive strategies as climate stress either tethered groups to certain resource locales and/or necessitated broader ranging residential movement. Dating to the end of the Late Prehistoric I (1050 B.P-750 B.P), numerous graves were unearthed in Young County at the Harrell Site in periods of Plains Villager occupation at the site, about A.D. 1200-1500. From the arrangements of the individual interments and the discovery of arrow points among the bones, these mass graves have been interpreted as the result of violent events - perhaps raids from enemies competing for increasingly scarce resources such as fertile, well-watered farmland. Coupled with similar evidence of violence from sites across the Southern Plains, the Late Archaic in North-Central Texas appears to be a turbulent time. Typically, sites dating to the Late Prehistoric I period are located within floodplains and adjacent terraces.

\section{Late Prehistoric II (750-250 B.P.)}

The xeric conditions proposed for the Late Prehistoric I may have continued into the Late Prehistoric II period, which catalyzed a shift to a short grass prairie environment (Prikryl 1990). These grasslands may have brought back bison to the region in greater numbers. While other areas of Texas seemed to practice a mobile lifestyle possibly centered on the exploitation of the bison, North-Central Texas was also influenced by more settled cultures to the north and east. Diagnostic projectile points for this time period include Fresno, Perdiz, Maud, Washita, and Harrell. Other artifacts commonly found in assemblages dating to this period are Nocona Plain ceramics and horticultural tools fashioned from bison scapulas. Prikryl (1990) notes that chert continues to be the favored source material for lithic tools. Sites from terrace locales continue to dominate the archeological record, with the bulk of them occurring near or within the Oak woods and Prairies/Blackland Prairie ecotone.

\section{Historic Period}

According to Conner (1959) the area of modern-day Wise County was originally included in the Peters Colony Grant given to a Louisville, Kentucky Company by the Republic of Texas between 1841 and 1843 with immigration to the area hailing from the upper south and the north (Meining 1969). With the area of Wise County occupying the "frontier" and still heavily trafficked by tribes, permanent Anglo settlement did not begin until 1853 with Sam Woody's homesteading approximately three miles north of the present location of the town of Aurora. In 1856, Wise County proper was organized from the larger boundary of Cooke County with the county seat county seat named Taylorsville in honor of General Zachary Taylor. The town was laid out by Absalom Bishop, an early settler in the region. Bishop, a member of the Texas Legislature, did not approve of Taylor's affiliation with the Whig Party, changed the name of the town to Decatur for Commodore Stephen Decatur. Over the next half-decade, the population continued to grow, burgeoned by the Butterfield Stage route which originally passed through Alvord, located within the LBJ National Grassland, before it was relocated through Decatur.

The late 1860s saw the establishment of four stores and a hotel in Decatur, which served as a supplier and market for local ranchers (Barton 2020). The eastern fork of the Chisholm Trail passed near Decatur in this period and is commemorated today by the town's annual event, the Chisholm Trail Barbeque. In 1882 the Fort Worth and Denver Railway reached Decatur, and the gambler's catch phrase "eighter from Decatur" was coined, according to local tradition, by a railway construction worker wanting to roll eights during a 
game of craps. During the 1880s and 1890s, Decatur prospered as a shipping point and market for local farmers. This prosperity was reflected in the establishment of Decatur Baptist College in 1892, the building of a new courthouse in 1896, and a population that grew from only 579 in 1880 to as much as 1,746 by 1890. The town of Decatur continued to grow in the early 20th century, from a population of 1,562 in 1904 to a peak of 3,200 in 1928.

Within the area that is now the LBJ National Grasslands, early settlements included Audubon and Flatrock with stock grazing along the prairies being the primary occupation early on. Following the establishment of the railroad through the region, cash crop farming also became a productive industrye (Jurney et al. 1989). The Grasslands were originally managed by the Rural Resettlement Administration and, later, by the United States Soil Conservation Service with the goal of returning eroded land to its natural state, until the early 1950s when ownership and management of its resources were transferred to the USFS. 


\subsection{PREVIOUS INVESTIGATIONS}

According to the Texas Historical Commission (THC) Historic and Archeological Sites Atlas (Sites Atlas), one previously recorded site and one previous survey are within the boundary of Unit 48. Site 41WS105/ 08130800055 is a prehistoric site of unknown temporal affiliation recorded in 2010 by Dixie Environmental Services Co., LP for a 3-D Seismic Survey. The site is defined as a light density prehistoric scatter without enough information to determine eligibility of the site (THC 2019).

Only one previous archeological project has been conducted within the boundary of Unit 48 that was completed in 2010 by Brazos Valley Research Associates (THC 2019). This project is listed as a 3-D seismic survey on behalf of Devon Energy Corporation. According to the Sites Atlas, it is noted as a partial survey and covers the entire extent of Unit 48.

No previously-recorded sites or previous archeological projects are recorded within or adjacent to Units 62 and 63. Additionally, no cemeteries, properties currently listed or eligible for listing in the National Register of Historic Places (NRHP), State Antiquities Landmarks (SALs), or historical markers are within or adjacent to the any of the Grasslands units (THC 2019) (Appendix D). 


\subsection{FIELD METHODS}

The goals of the cultural resources survey were as follows:

- Determine if cultural materials are present within the APE through pedestrian survey and shovel testing of the APE;

- If archeological deposits are present within the APE, determine their spatial extent;

- If archeological deposits are present within the APE, attempt to determine the general cultural affiliation/age of these deposits;

- Document any historic standing structures within the APE

Fieldwork was conducted by TRC archeologists Josh Haefner, Steven Sarich, Benjamin Johnson and Hicks \& Company archeologists Gregg Cestaro and Haley Wilkerson from October 31 - November 8 and December 4-6, 2019 and followed the guidelines and survey standards set forth by the USFS, Council of Texas Archeologists (CTA), and the THC as coordinated with the USFS through a proposed archeological survey methodology and research design. The Area of Potential Effects (APE) consists of the entirety of three Grasslands unit locations where proposed perimeter fence reconstruction will occur. The three Grasslands units include Unit 48, Unit 62, and Unit 63. Grasslands Unit 48 has an approximate perimeter measurement of 5,272 meters $\mathrm{m}[17,297 \mathrm{ft}]$ and spans approximately $190 \mathrm{ac}$. Unit 62 has an approximate perimeter measurement of 1,811 $\mathrm{m}[5,942 \mathrm{ft}]$ and spans approximately $49 \mathrm{ac}$. Unit 63 has an approximate perimeter measurement of 4,035 $\mathrm{m}[13,238 \mathrm{ft}]$ and spans approximately $160 \mathrm{ac}$. The total APE for the three Grasslands units is 399 ac. Though impacts from fencing and fireline constructing will likely be limited to a 40-foot corridor around each unit, shovel testing and pedestrian survey covered the entirety of each Grasslands unit to evaluate and record any cultural resources located within their boundaries.

The field effort consisted of pedestrian survey supplemented with shovel testing of the APE. Minimally, TRC excavated shovel tests within each of the Grasslands units at $30 \mathrm{~m}$ transect spacing with shovel test intervals no greater than $150 \mathrm{~m}$. In certain instances, this number was increased during site recording to gather additional data on deposition. Shovel tests were approximately 30-to 40-centimeter (cm) (11.8inch) in diameter, and excavated to at least 80 centimeters in depth, the base of Holocene deposits, or impenetrable bedrock whichever was encountered first. Vertical control was maintained for each shovel test in arbitrary $10 \mathrm{~cm}$ levels. Excavated soils were screened through 1/4-inch (6.25- millimeter [mm]) hardware mesh to ensure consistent artifact recovery. Standardized field notes were maintained for each shovel test describing location, soil depth, color, texture, stratigraphy, as well as the types of artifacts recovered. The location and results of all shovel tests were recorded on electronic forms created by TRC with Fulcrum, a mobile form builder and data collection program.

A total of 412 shovel tests were excavated during the archeological survey. Of these tests, 404 were negative for cultural materials. In addition to these tests, 65 points were recorded as "No Dig" locations due to ground disturbance, slope, or other impediment. Six shovel tests were positive for cultural materials. A total of three new archeological sites were recorded during the current investigations and the site boundary to previously recorded site $41 \mathrm{WS} 105$ was extended approximately 124 m northwest. As shovel testing at two of the new sites, $41 \mathrm{WS} 160$ and 41WS161, noted no buried cultural deposits and historic cultural materials were observable solely on the ground surface, these site boundaries were established by the mapping of the 
horizontal distribution of artifacts along the ground surface. However, the extended boundary to site 41WS105 and delineation of site 41WS159 were based on both the distribution of positive shovel tests and the horizontal distribution of artifacts on the ground surface.

Representative project overview photographs, site photographs, and in situ artifact and feature photographs were taken throughout the project. An artifact collection policy, as coordinated with the USFS, was followed for cultural materials identified during the survey. No standing structures over 45 years of age were observed within the APE. The final report, field notes, photographs, shapefiles, and associated paper and electronic records will be housed at the TRC office in Austin, Texas. Collected artifacts and the associated report and materials will be curated at the Center for Archaeological Studies in San Marcos, Texas. 


\subsection{RESULTS}

As noted above, the APE was determined in coordination with the USFS consisted of three Grasslands units within the LBJ National Grassland, totaling 399 ac in size. TRC archeologists performed a pedestrian survey and shovel testing within each Grasslands unit from October 31 - November 8 and December $4-6,2019$. Observed disturbances within the three Grasslands units was minimal, with some noted areas of erosion and clear-cut corridors particularly around the Grasslands unit boundaries along the existing fence lines. With the exception of a small number of underground pipeline corridors, the sporadic use and maintenance of two-track roads, and fencing, and the use of the land for federal public hunting, the three Grasslands units are largely devoid of landform modification. Vegetation of the APE was typical of Wise County and Cross Timbers ecology, as well as a substantial amount of secondary growth including green briar. The northern portion of Unit 48 consists of floodplain hardwood forest and post oak woodland giving way to hardwood motte and woodland and dominated by savanna grassland to the south. Vegetation of Unit 62 consists primarily of savanna grassland with hardwood motte and woodland with scattered areas of erosion, and large area of post oak woodland to the southwest. Unit 63 consists of post oak woodland centered to the northeast surrounded by savanna grassland. Some riparian herbaceous vegetation and riparian hardwood forest is present in linear bands to the southwest. (Figures 6-1 - 6-3).

Ground surface visibility was poor, less than five percent in most places apart from sporadic areas of heavy erosion, and occasionally rising between approximately 10 to 30 percent in areas of savanna grassland. Soils within Unit 48 generally consisted of sandy loam (10YR 3/2) or sandy clay loam soils (7.5YR 5/2) from 0 to 30 centimeters below ground surface (cmbs) followed by clay B-horizon soils (5YR 6/4), and sandy clay soil (5YR 4.3) from 0 to $20 \mathrm{cmbs}$ over a shallow bedrock layer in the southwest portion of the Grasslands unit. Deep sand (7.5YR 6/4) was noted in and around 41WS105 and typically went from 80 to $100 \mathrm{cmbs}$. Soils within Unit 62 generally consisted of silty clay loam (7.5YR 3/3) or clay loam (10YR $5 / 4$ ) from 0 to $20 \mathrm{cmbs}$ followed by shallow, reddish brown clay B-horizon soils (2.5YR 2.5/4). Shovel test depth was limited on several occasions due to heavily compacted soils. Soils within the savanna grassland portions of Unit 63 generally consisted of clay loam (10YR 3/6) from 0 to $30 \mathrm{cmbs}$ with underlying red clay B-horizon soils (2.5YR 4/6). Soils within the wooded section of Unit 63 generally consisted of sandy loam (10YR 4/4) from 0 to $30 \mathrm{cmbs}$ with underlying reddish-brown sandy clay (5YR 4/4) or red clay (2.5YR 4/8) B-horizon soils. Complete shovel test data is included as Appendix B.

Seven shovel tests were positive for cultural materials. A total of three new archeological sites were recorded during the current investigations and the site boundary to previously recorded site 41WS105 was extended approximately $124 \mathrm{~m}$ northwest. As shovel testing at two of the new sites, $41 \mathrm{WS} 160$ and $41 \mathrm{WS161}$, noted no buried cultural deposits and historic cultural materials were observable on the ground surface, these boundaries were established by the mapping of the horizontal distribution of artifacts along the ground surface. Extended boundary to $41 \mathrm{WS} 105$ and delineation of $41 \mathrm{WS} 159$ were based on both the distribution of positive shovel tests and the horizontal distribution of artifacts on the ground surface. One isolated historic feature/structure, a galvanized steel windmill, was identified within Unit 63 along the southwest boundary near County Road (CR) 2648 (Appendix D). 


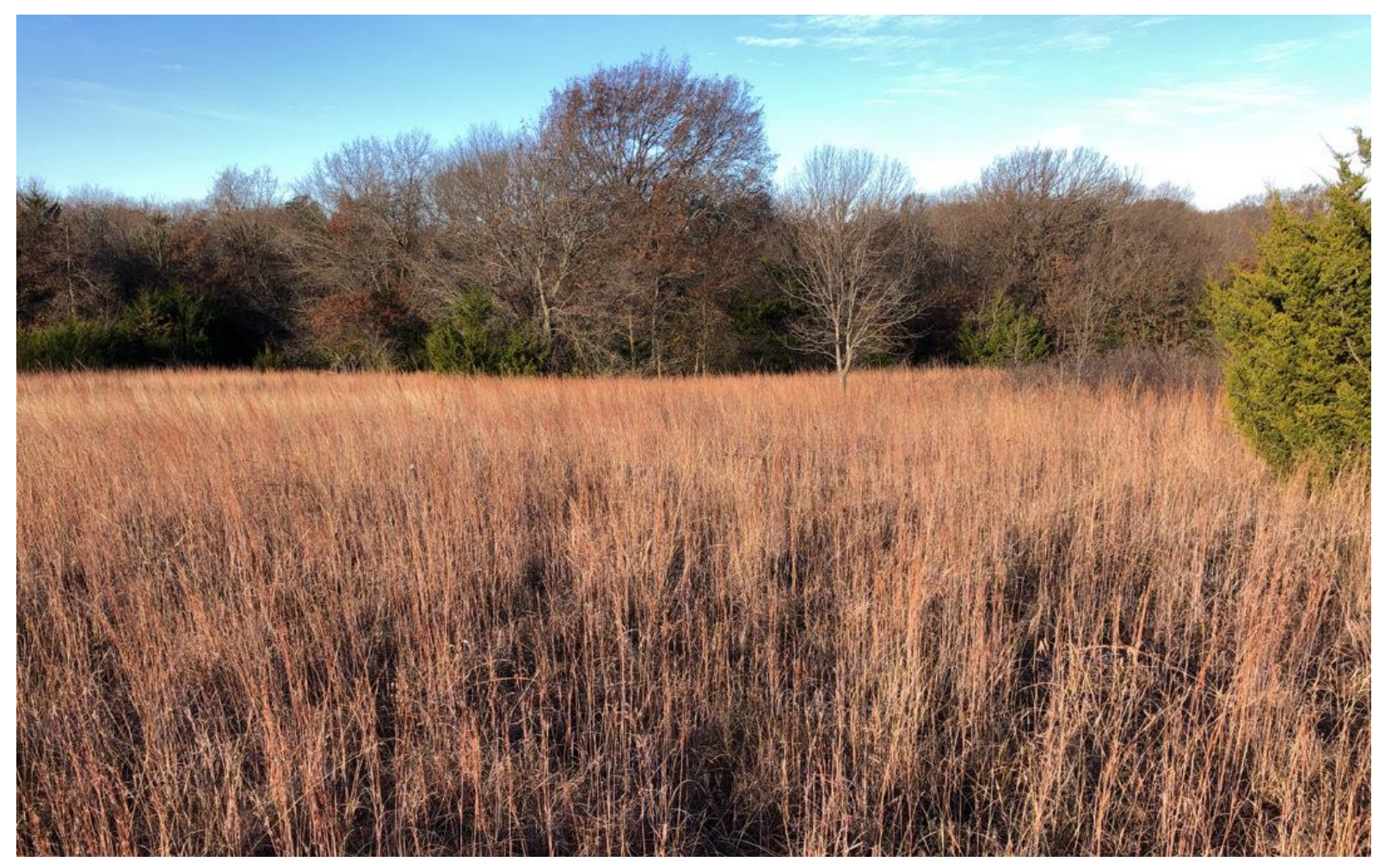

Figure 6-1 Overview of vegetation at Unit 48, facing north.

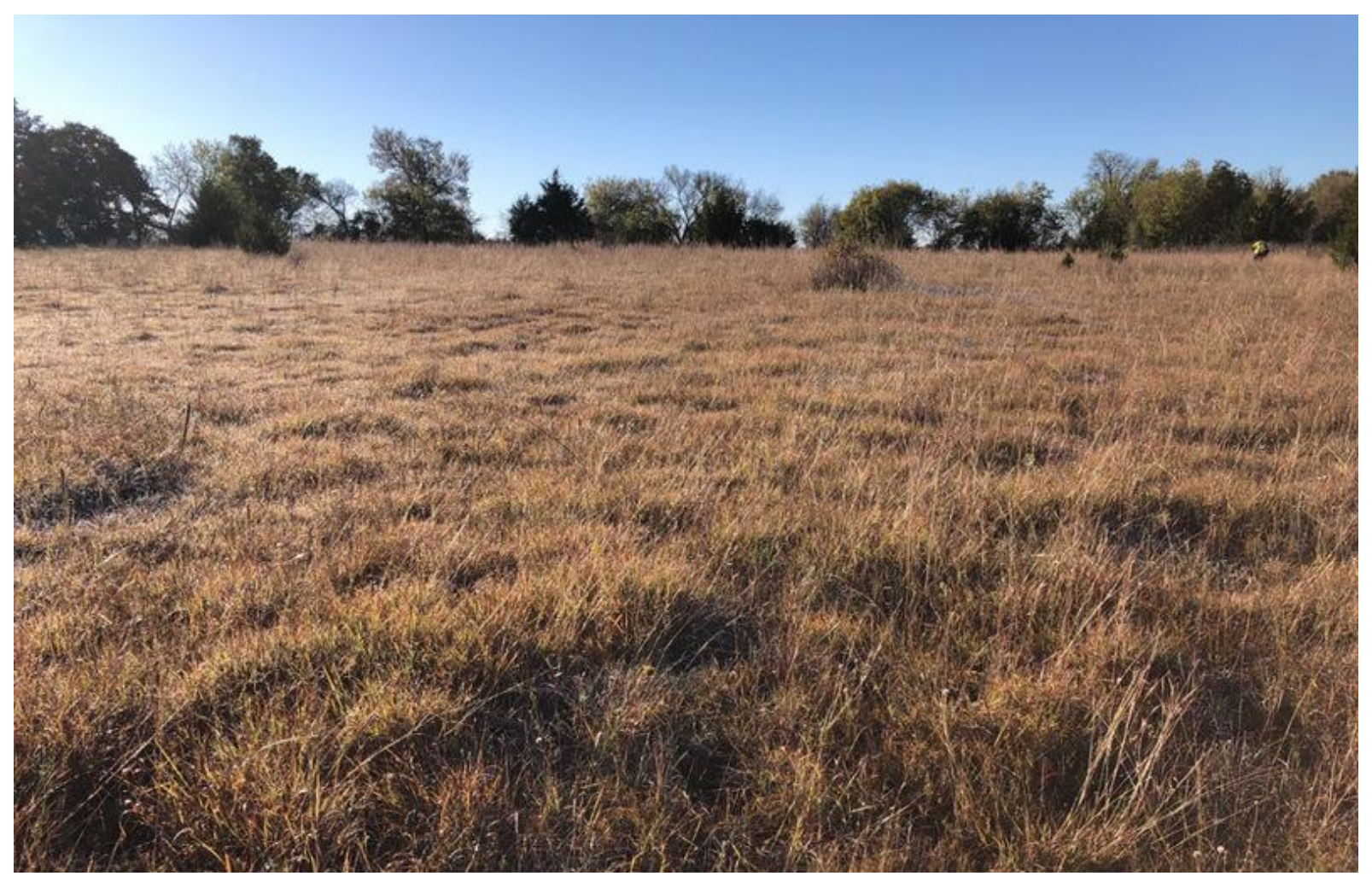

Figure 6-2 Overview of vegetation at Unit 62, facing south. 


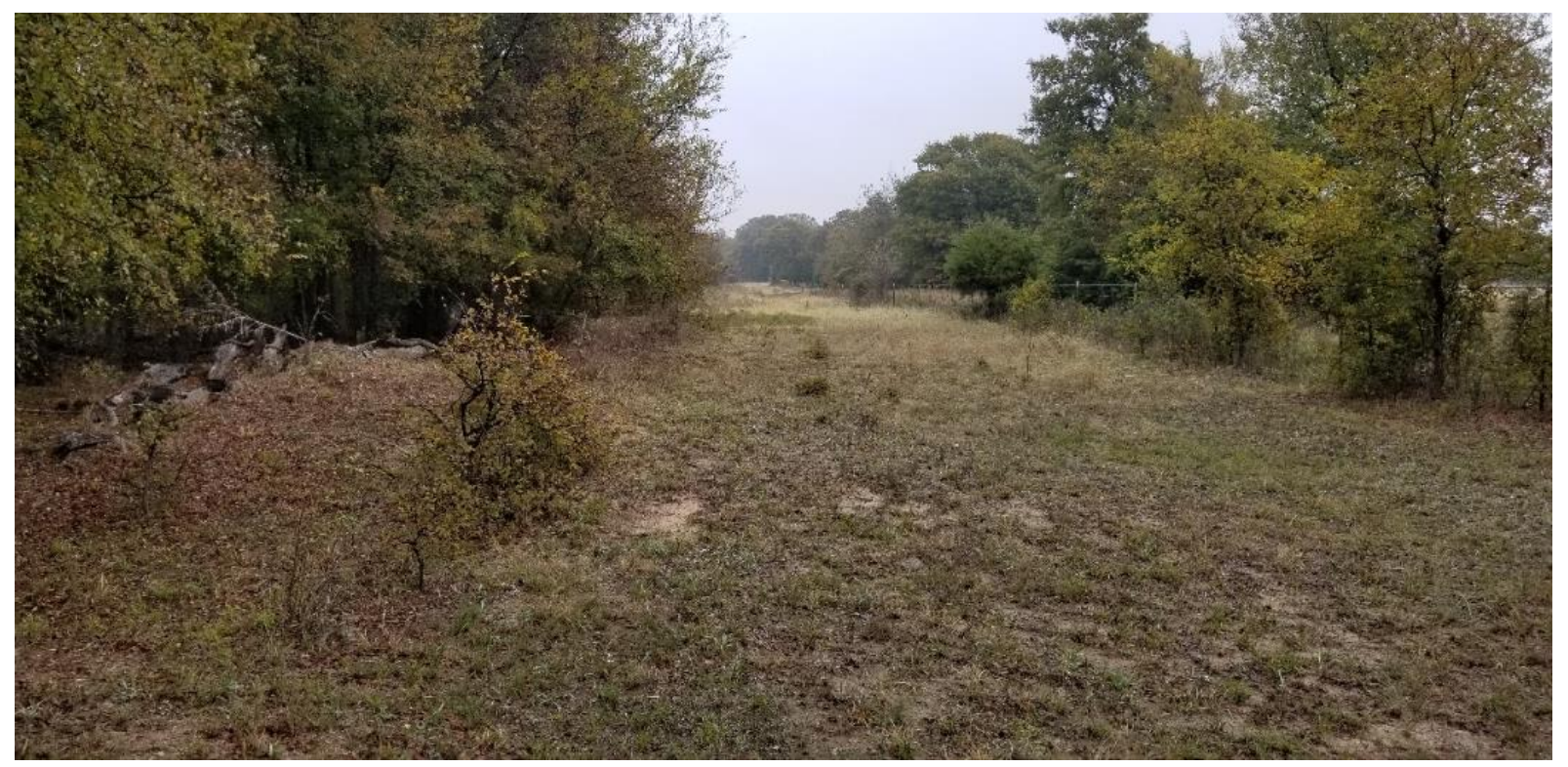

Figure 6-3 Overview of vegetation at Unit 63, facing southeast. 


\section{Site 41WS105/08130800055 Extension}

During the survey of Unit 48, previously recorded site 41WS105 was revisited to determine if additional cultural materials were present within or adjacent to the current site boundaries. The original site boundary is located on a slight ridge overlooking an unnamed tributary of Black Creek and measures approximately 6,420 square meters. $41 \mathrm{WS} 105$ was originally recorded during a seismic survey in 2010 on behalf of the Forest Service. The site was originally described as a light density prehistoric scatter on a slight finger ridge running roughly north-south and parallel to a tributary of Black Creek (Shaddox and Hall 2010). It is situated on the western edge of the ridge top and continues down the western slope towards the drainage. At that time, the only artifacts found at this site are described by the analyst as debitage, and very little could be said with no temporally or functionally diagnostic artifacts recorded and an absence of observed features. During the current survey, the site was revisited, and additional materials were found northwest and adjacent to the previously recorded site (Appendix D). The extension is located northwest of the previously recorded boundary with additional materials found in a clear-cut corridor with mixed hardwood forest on either side (Figure 6-4). Heavy slopes are present along the western boundary. The geology consists of Early Cretaceous Antlers Sand. The 1967 Geologic Atlas of Texas, Sherman Sheet notes that Antlers Sand is commonly found in Eastern part of Trans-Pecos and High Plains and consists of sand, clay, and conglomerate. The lower and upper parts are mostly sand, the middle part chiefly clay, and grades northward to interbedded sand and clay. Sand is fine to coarse grained, conglomeratic in lower part, clayey in upper part, and brownish-yellow. Conglomerate, chert, quartz, and quartzite are found as pebbles and granules. Thickness can be as much as $200 \mathrm{ft}$ but is variable because of the irregular surface on which it was deposited. Soils in the area were found to be consistent with the USDA Web Soil Survey (2015) which classifies the soils as Patilo-Heaton fine sands with 3 to 12 percent slopes. These soils are characteristically very deep and located on gently sloping to strongly sloping uplands (USDA 1989). The typical soil profile documented during shovel testing consisted of dark brown sandy loam (10YR 4/2) from 0 to $20 \mathrm{cmbs}$ overlying brown sand or sandy loam (10YR 5/3) from 20 to $100 \mathrm{cmbs}$, though occasionally terminating in reddish brown sand (5YR 4/4) between 60 to $80 \mathrm{cmbs}$. The site extension was delineated using $10 \mathrm{~m}$ and $20 \mathrm{~m}$ radial shovel tests in cardinal directions until two consecutive negative shovel tests were recorded. A total of 19 shovel tests were excavated and only three were positive for cultural materials (177-SS, 52-JH, and 63-BJ) while 16 were negative (178-SS, 176-SS, 69-BJ, 183-SS, 68-BJ, 67-BJ, 60-BJ, 61-BJ, 180-SS, 179-SS, 181-SS, 182-SS, 66-BJ, 65-BJ, 64-BJ, and 62-BJ). Subsequent to shovel testing, an approximate $10 \mathrm{~m}$ boundary was established based on the distribution of positive shovel tests, and a small number of surface artifacts extended the previously recorded site boundary an additional $124 \mathrm{~m}$ to the northwest along the clear-cut corridor. The extension measures 2,406 square-meters yielding a total revised site size of approximately 8,826 square meters. The site extension consists of nine pieces $(n=9)$ of lithic debitage found subsurface with one large piece $(n=1)$ of white chert debitage observed on the surface (Figures 6-5 to 610). Subsurface lithic debitage was predominantly found between 20 to $40 \mathrm{cmbs}$, though two pieces were found between 60 to $70 \mathrm{cmbs}$. The small amount of material and the lack of diagnostic artifacts seems to support the previous description of the site as a limited activity area. Because the site extension is located in a modified clear-cut corridor and no diagnostic artifacts were discovered during the survey, site 41DM273 has very limited research value and does not currently meet any of the criteria necessary for consideration as eligible for listing on the NRHP. 
Cultural Resources Survey and Evaluation of Archeological Sites 41WS105, 41WS159, 41WS160, and 41WS161 for the Proposed Fence Line Project in Grasslands Units 48, 62, and 63, LBJ National Grassland, Wise County, Texas
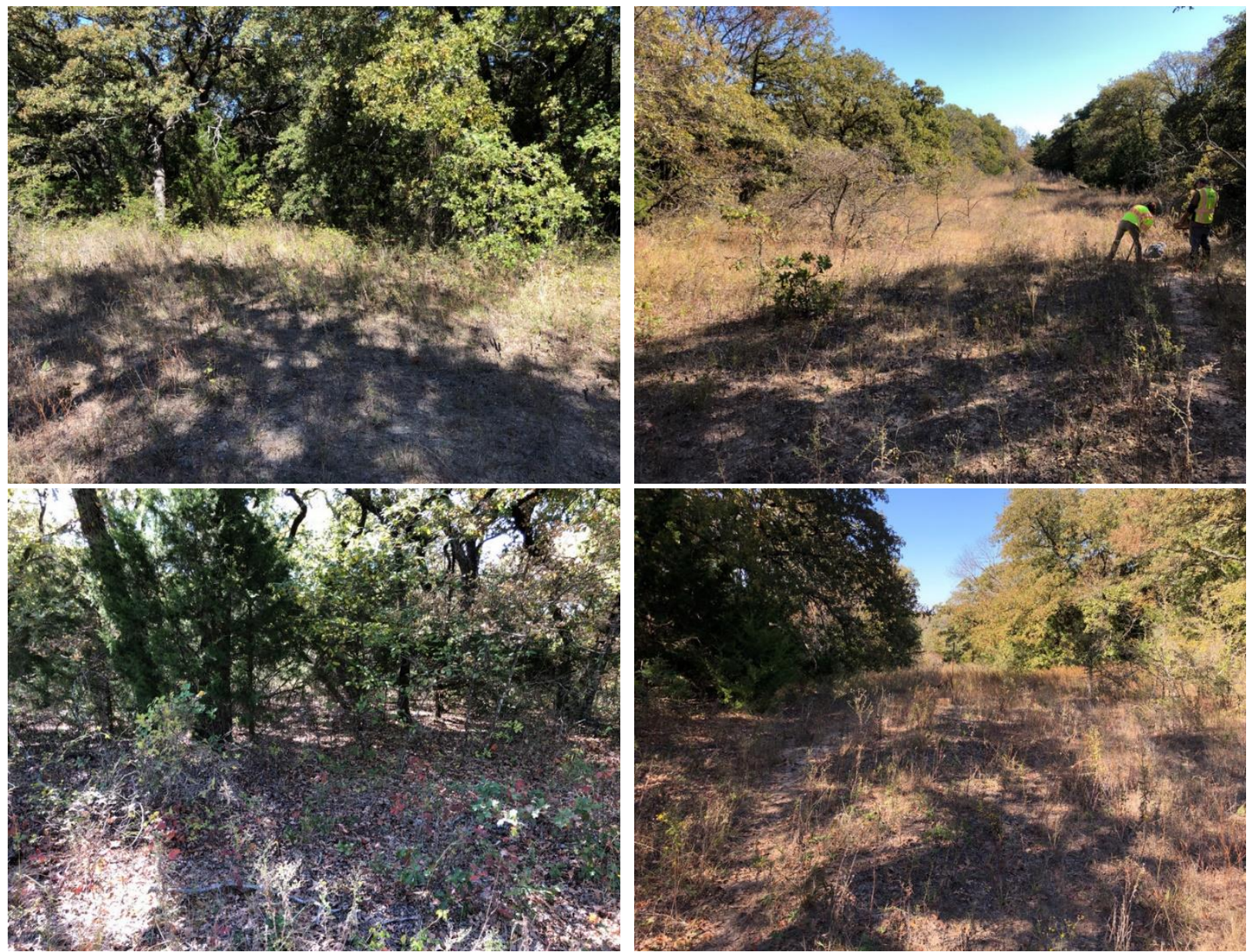

Figure 6-4 Site 41WS105 overviews facing north, east, southwest, and west (left to right). 


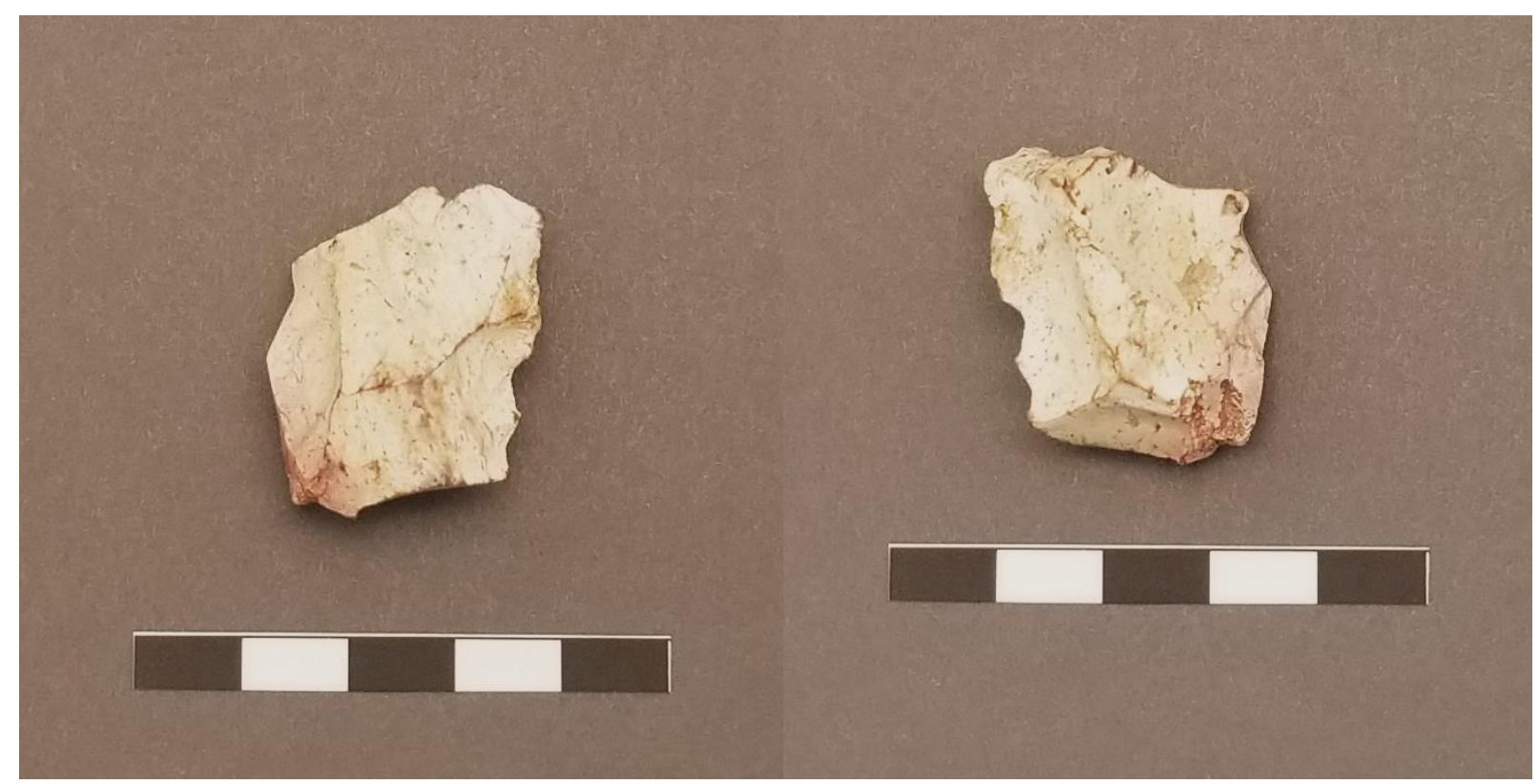

Figure 6-5 White chert debitage recorded on the surface of 41WS105 Extension.

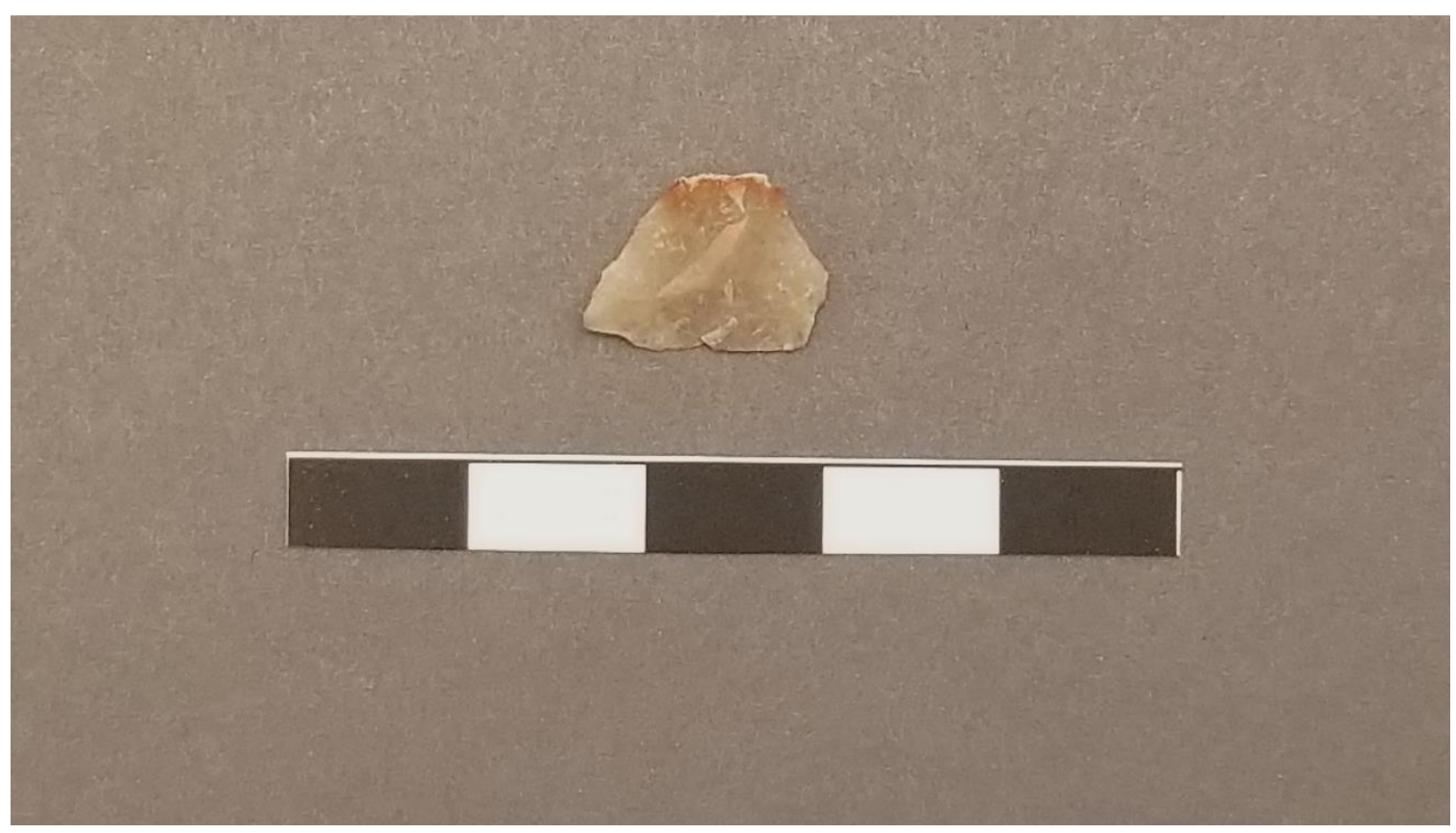

Figure 6-6 Debitage recorded in shovel test $177 \mathrm{SS}$ at $20-30 \mathrm{cmbs}$. 


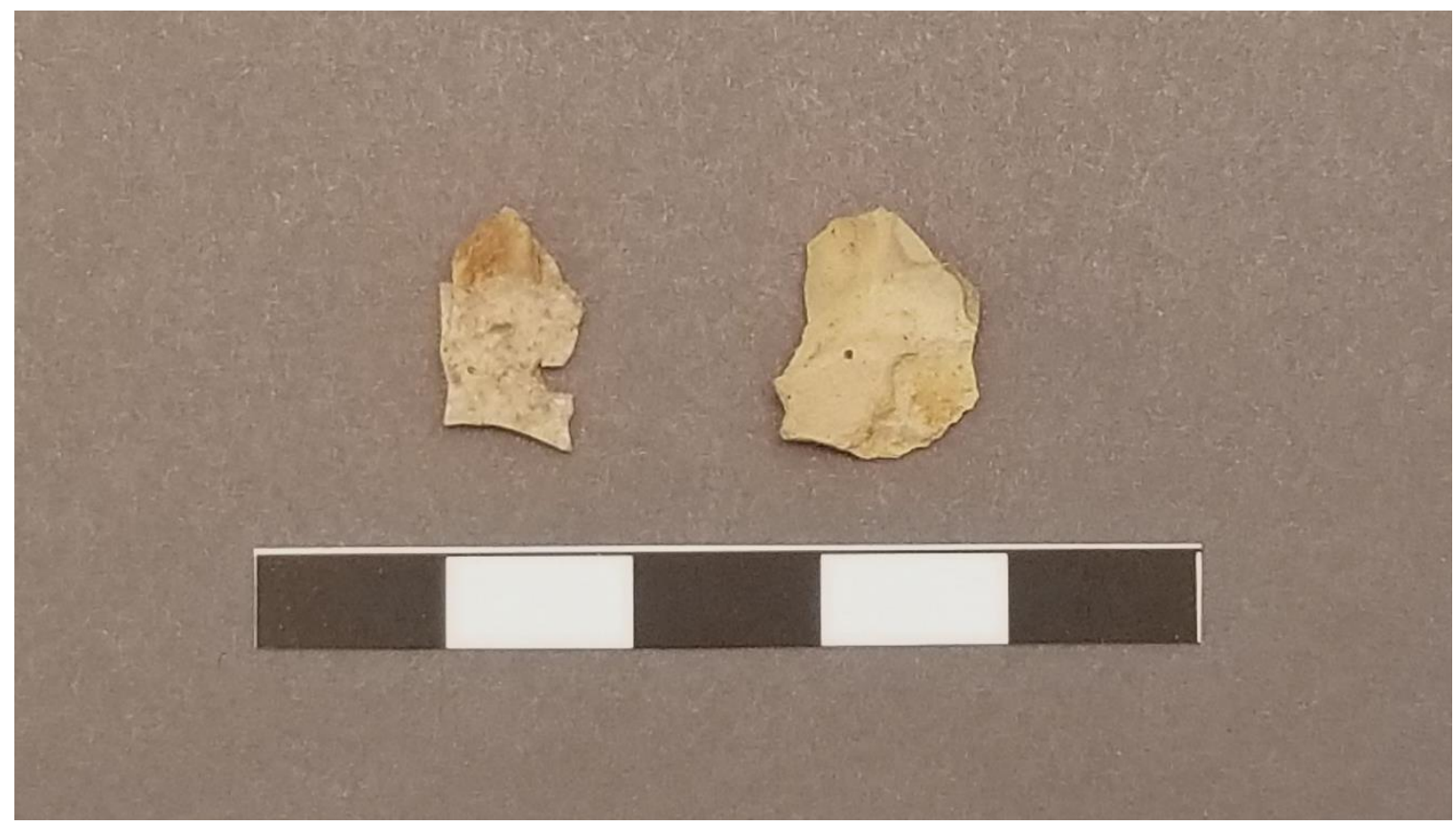

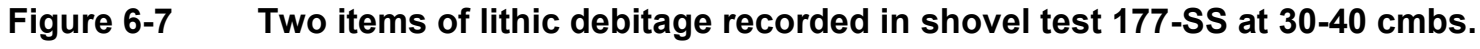

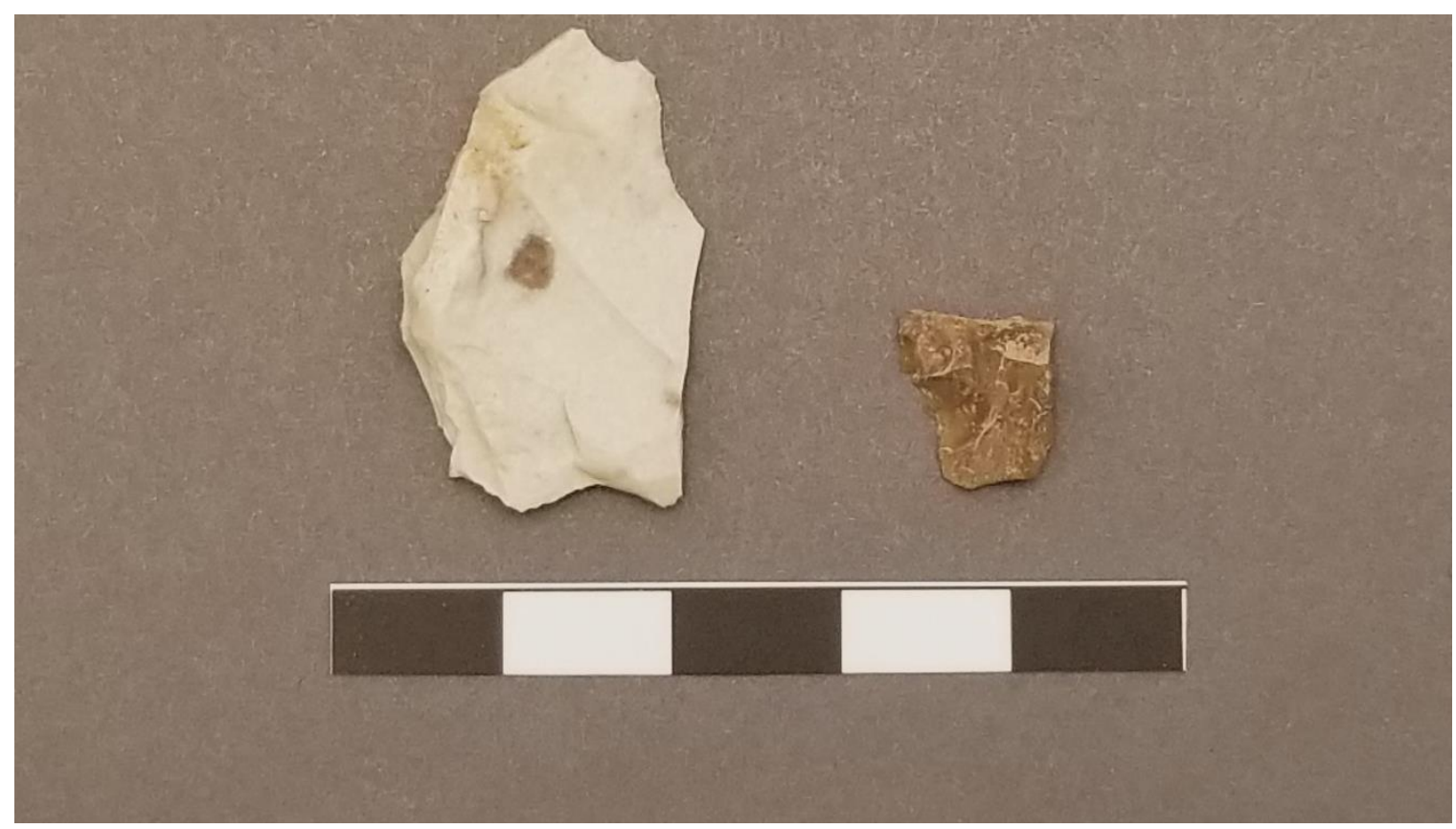

Figure 6-8 Two items of debitage recorded in shovel test 177-SS at $60-70 \mathrm{cmbs}$. 


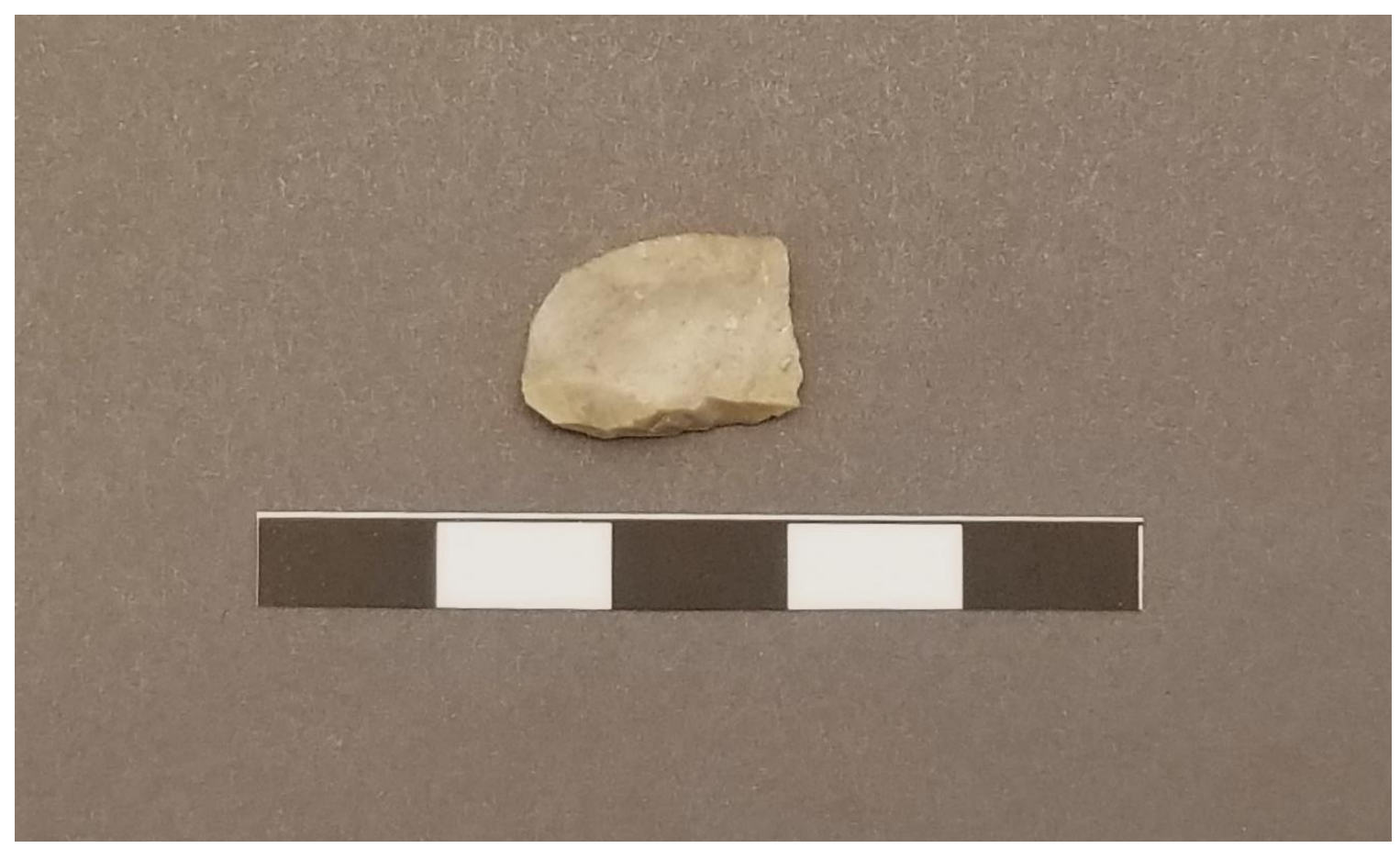

Figure 6-9 Debitage recorded in shovel test $52-\mathrm{JH}$ at $20-30 \mathrm{cmbs}$.

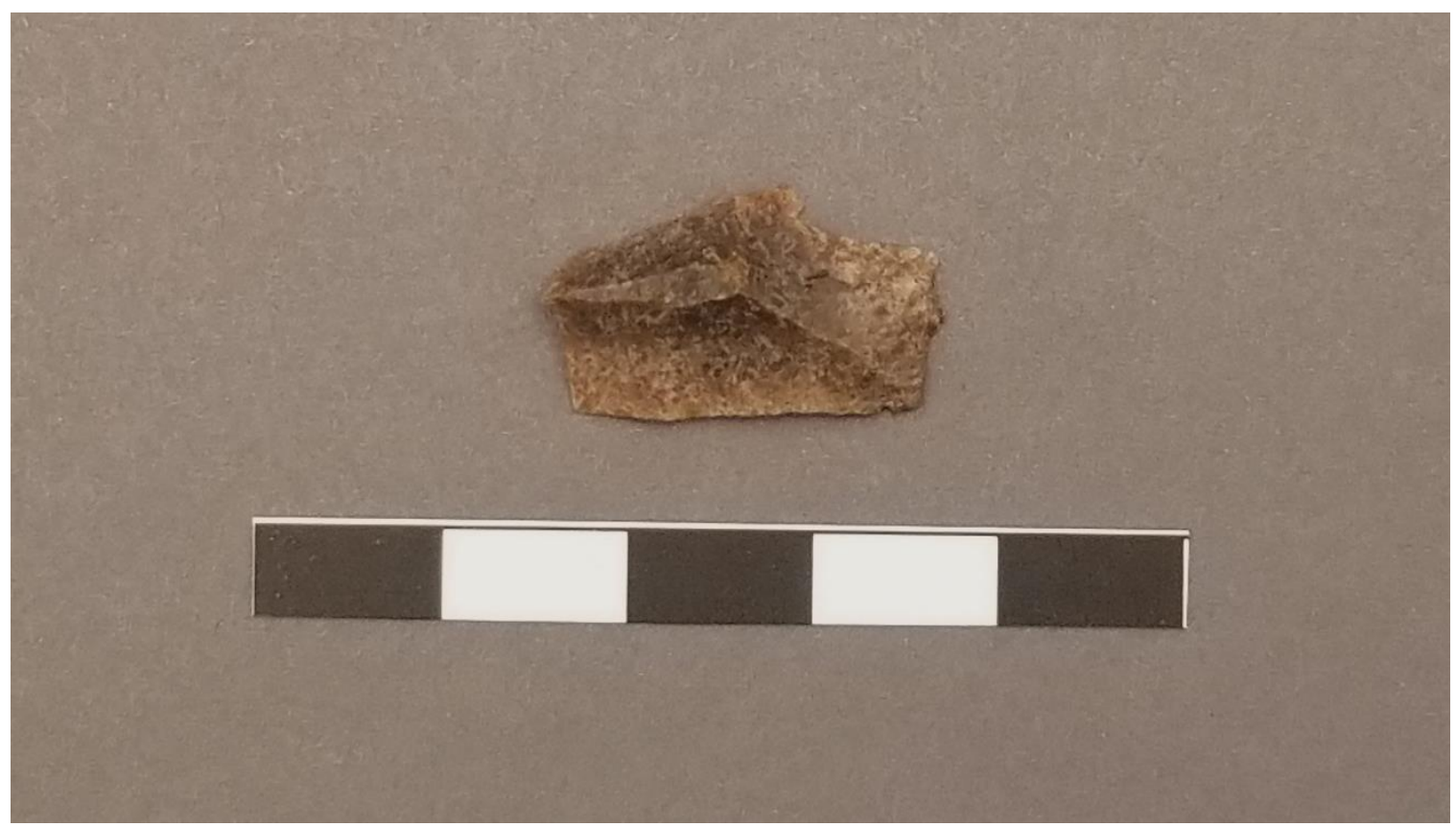

Figure 6-10 Debitage recorded in shovel test 63-BJ at 60-70 cmbs. 


\section{WS159/08130800525}

Site 41WS159 is an assemblage of historic cultural materials partially located within a mixed grass prairie setting with the eastern boundary of the site overlapping a small stand of mixed hardwood trees (Appendix D). The northeast boundary overlaps a channelized drainage that parallels the gravel road that leads to a pump station. A gate and dirt path parallels the drainage running, northwest to southeast (Figure 6-11). A transmission line corridor runs northeast to southwest and parallels CR 2648. The geology consists of Early Cretaceous Antlers Sand. The 1967 Geologic Atlas of Texas, Sherman Sheet notes that Antlers Sand is commonly found in Eastern part of Trans-Pecos and High Plains and consists of sand, clay, and conglomerate. The lower and upper parts are mostly sand, the middle part chiefly clay, and grades northward to interbedded sand and clay. Sand is fine to coarse grained, conglomeratic in lower part, clayey in upper part, and brownish-yellow. Conglomerate, chert, quartz, and quartzite are found as pebbles and granules. Thickness can be as much as $200 \mathrm{ft}$ but is variable because of the irregular surface on which it was deposited. Topographically the area is uniformly flat. There was some evidence of push piles located in the wooded area perhaps related to the dirt road or channelized drainage. Subsoil consists of shallow, red clay typically found no deeper than 30 to 40 centimeters below surface. Measuring approximately 1,103 square meters in size, site $41 \mathrm{WS} 159$ is a small assemblage of historic artifacts found at surface and subsurface. The site was delineated using $10 \mathrm{~m}$ and $20 \mathrm{~m}$ cardinal radial shovel tests until two consecutive negative shovel tests could be established. Of the 20 recorded shovel tests only four were positive for historic cultural materials (101-SS, 99-SS, 72-SS, and 80-JH) while 12 were negative (181-JH, 56-JH, 191SS, 70-BJ, 69-BJ, 75-BJ, 76-BJ, 72-BJ, 71-BJ, 73-BJ, 185-SS, 184-SS, and 100-SS), and three were recorded as 'No dig' tests due to their location in a drainage or in proximity to the transmission line pole (188-SS, 187-SS, 186-SS). The historic assemblage consists of one floral pattern, flow blue whiteware sherd $(n=1)$, one undecorated whiteware sherd $(n=1)$, one undecorated ironstone sherd $(n=1)$, one stoneware sherd $(n=1)$, one green glass shard $(n=1)$, two milk glass shards $(n=2)$, one colorless, molded glass shard $(n=1)$, and sixteen colorless container glass shards likely from the same vessel $(n=16)$. A total of 24 artifacts were found (Figures 6-12 - 6-16). Some cut stone was found near the eastern boundary of the site toward the road and along the fence line (Figure 6-17). Two cut stone pieces appear to be in sequence and measures approximately 20 inches [50.8 centimeters] in length. The stones are approximately 4 inches wide [10.2 centimeters]. Additional cut stones were nearby but scattered. According to the THC's Key to Historic Ceramics (2006) the floral pattern, flow blue sherd dates between 1835 and 1900. Additionally, ironstone ranges from the 1840 s to the 1930s. According to the SHA Bottle Guide (2018), the milk glass shards likely date between 1870 and 1950. The colored glass shard appears to be citron green which dates to the last quarter of the 19th century. The colorless glass likely does not date prior to 1870 , but is likely more recent than that (Toulouse 1969). Some modern trash left by hunters was found within the stand of trees. Push piles were also found within the stand of trees to the east, possibly associated with the channelized drainage or dirt roadway to the northeast. Archival research was conducted at the Wise County Clerk's office and the Wise County Heritage Museum to determine former occupation and to obtain any family history information regarding past property owners. According to an 1895 historic plat of Wise County, the land on which Unit 62 and 63 are located was part of the J.W. Crunk survey (Pressler 1895). A portion of this land was owned by J.G. Graves and conveyed to J. Fortenberry in 1886 (Wise County Clerk 1886). According to the Fortenberry family archives, the family moved to Texas from Arkansas in 1858 and, over time, built several homes around Greenwood and Slidell (Wise County Heritage Museum n.d.). After careful review of the Fortenberry family archives at the Wise County Heritage Museum, no definitive 
account of a farmstead at the location of the artifact assemblage was found. However, according to additional deed research, J. Fortenberry conveyed the land to J.B. Howard on February 4, 1903 (Wise County Clerk 1903). According to family history records, John Barnett Howard and Lillie Caroline Chance moved to Texas at the turn of the century and purchased a farm two miles west of Greenwood (WCHSC 1982). This is the only written record of a farmstead located within the general vicinity of the artifact assemblage. The plot of land that J.B. Howard purchased was subsequently conveyed to J.T. Washburn in 1910 (Wise County Clerk 1910). James Thomas Washburn was born in 1868 and moved to Wise County around 1906 where he "farmed in the Greenwood community until Mrs. Washburn's death in 1931" (Wise County Messenger 1954). While this is a vague account, there is a good possibility that this is the same farm formerly owned by J.B. Howard. Noted impacts include natural erosion, as well as artificial impacts from the channelized drainage, dirt road, the installation of transmission line poles, and push piles located in the wooded area (Figure 6-18). There is also anecdotal evidence from hunters in the area that a hunting interest group occasionally does trash clean up within the Grasslands units and may constitute an unintentional, artificial impact. Because of the small number of commonly found historic materials and several natural and artificial disturbances, site 41WS159 has very limited research value and does not meet any of the criteria necessary for consideration as eligible for listing on the NRHP.
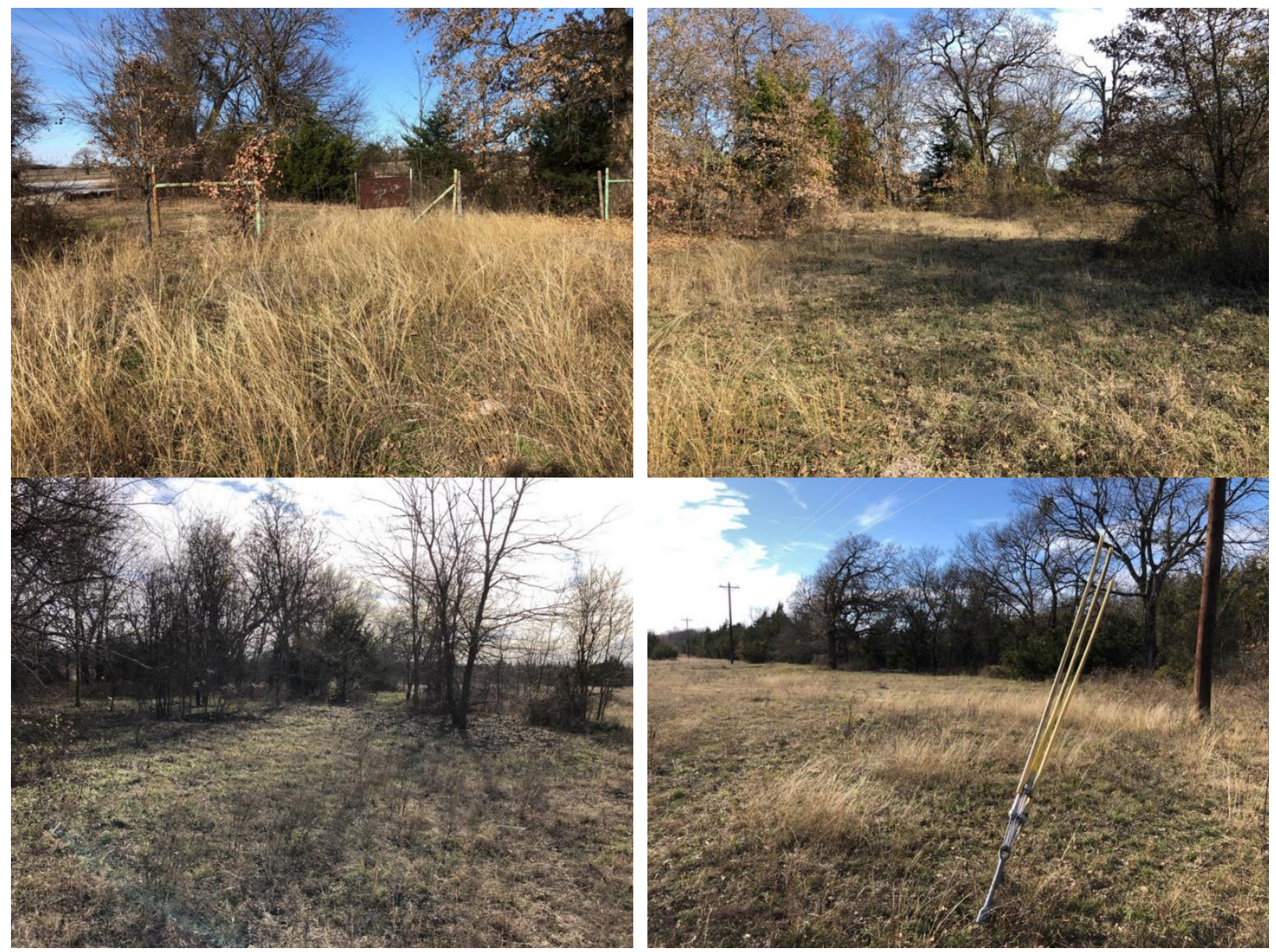

Figure 6-11

Overviews of 41WS159, facing north, east, south, and west (left to right). 


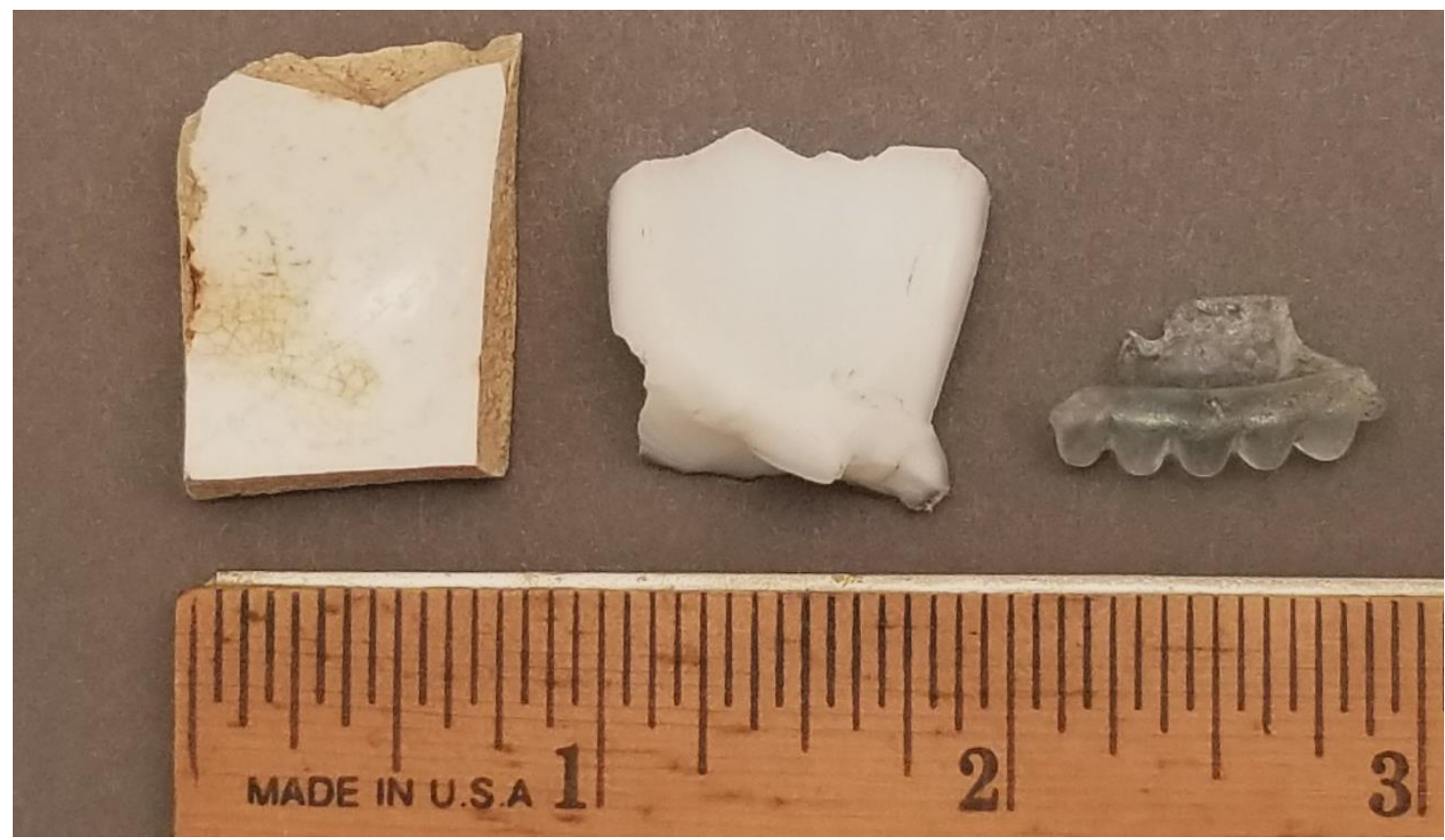

Figure 6-12 Ironstone, milk glass, and molded glass recorded in 72-SS at 0-10 cmbs.

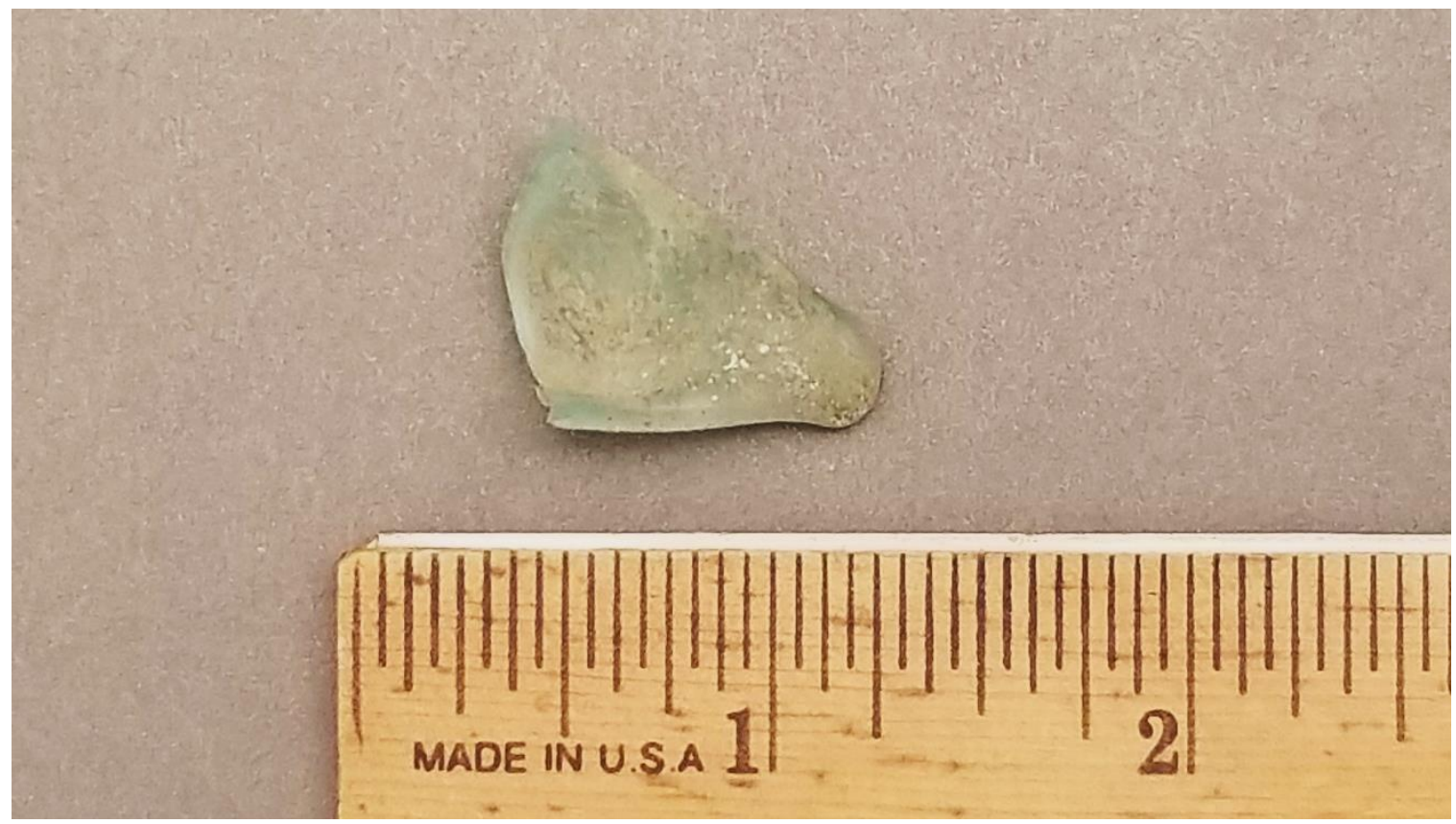

Figure 6-13 Green glass recorded in $72-\mathrm{SS}$ at $10-20 \mathrm{cmbs}$. 


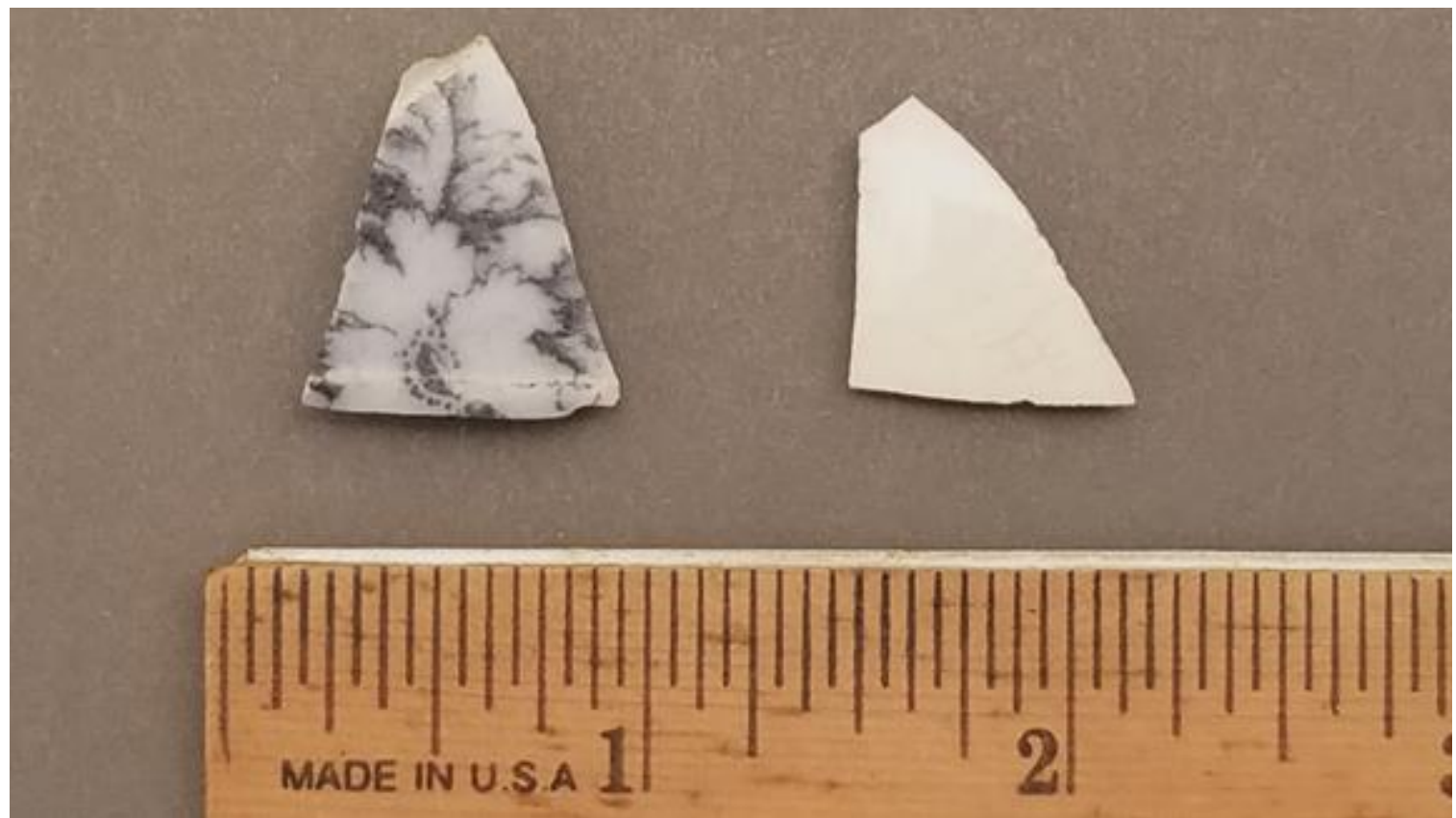

Figure 6-14 Transfer print sherd and plain whiteware sherd recorded in 72-SS at 20-30 cmbs.

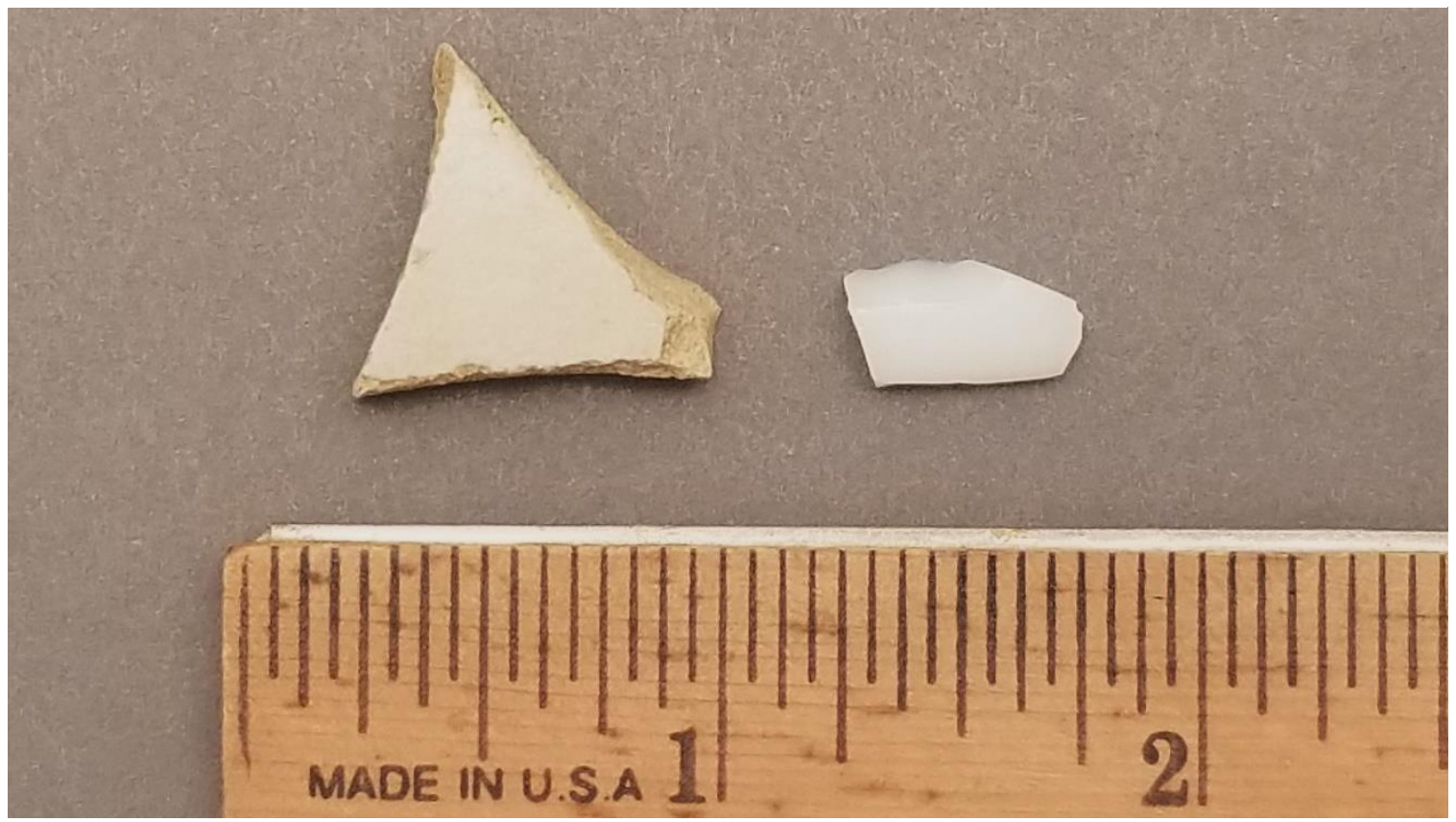

Figure 6-15 Undecorated stoneware sherd and milk glass recorded in 99-SS at 0-10 cmbs. 


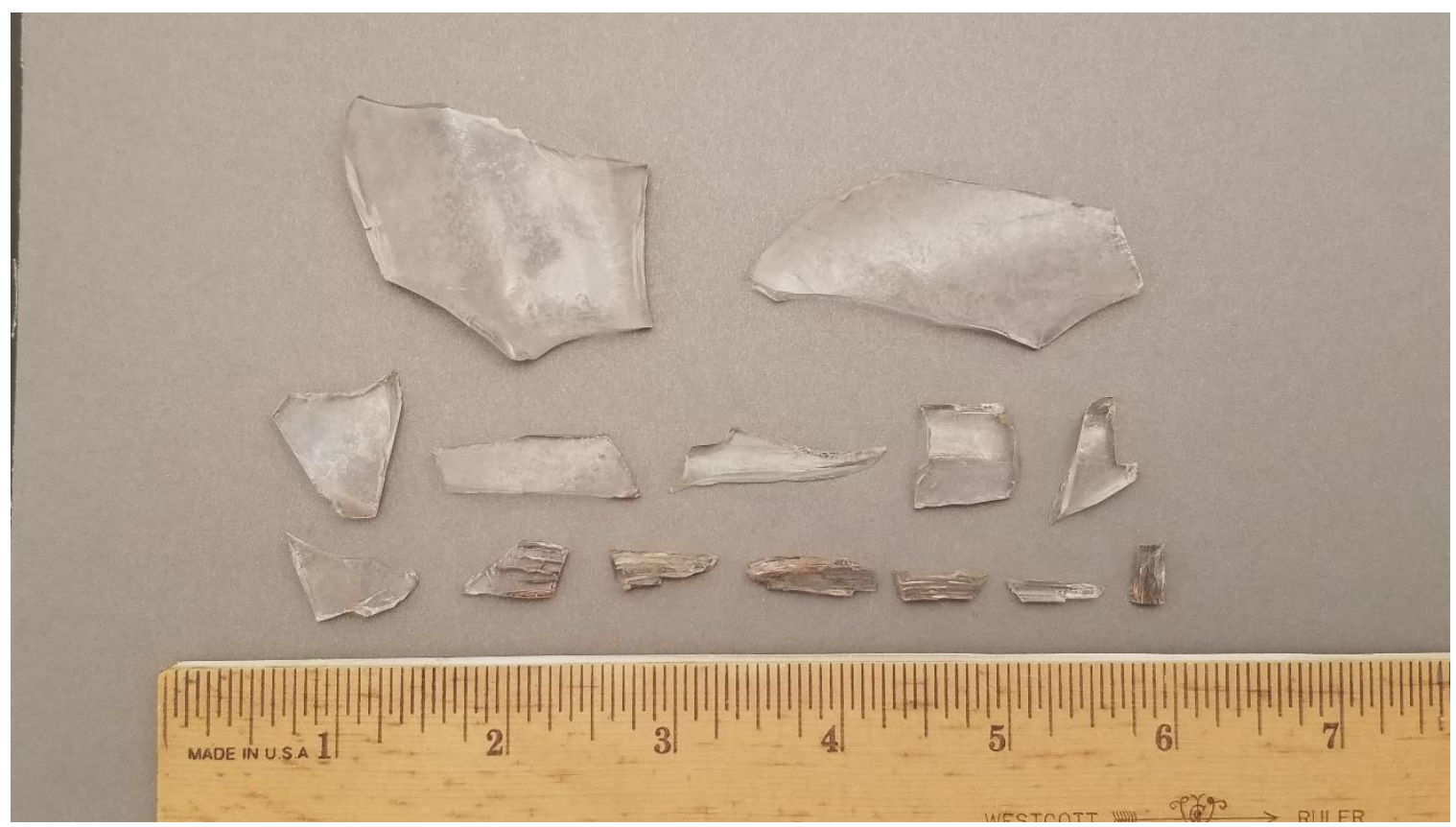

Figure 6-16 Container glass recorded in 101-SS at 0-10 cmbs.

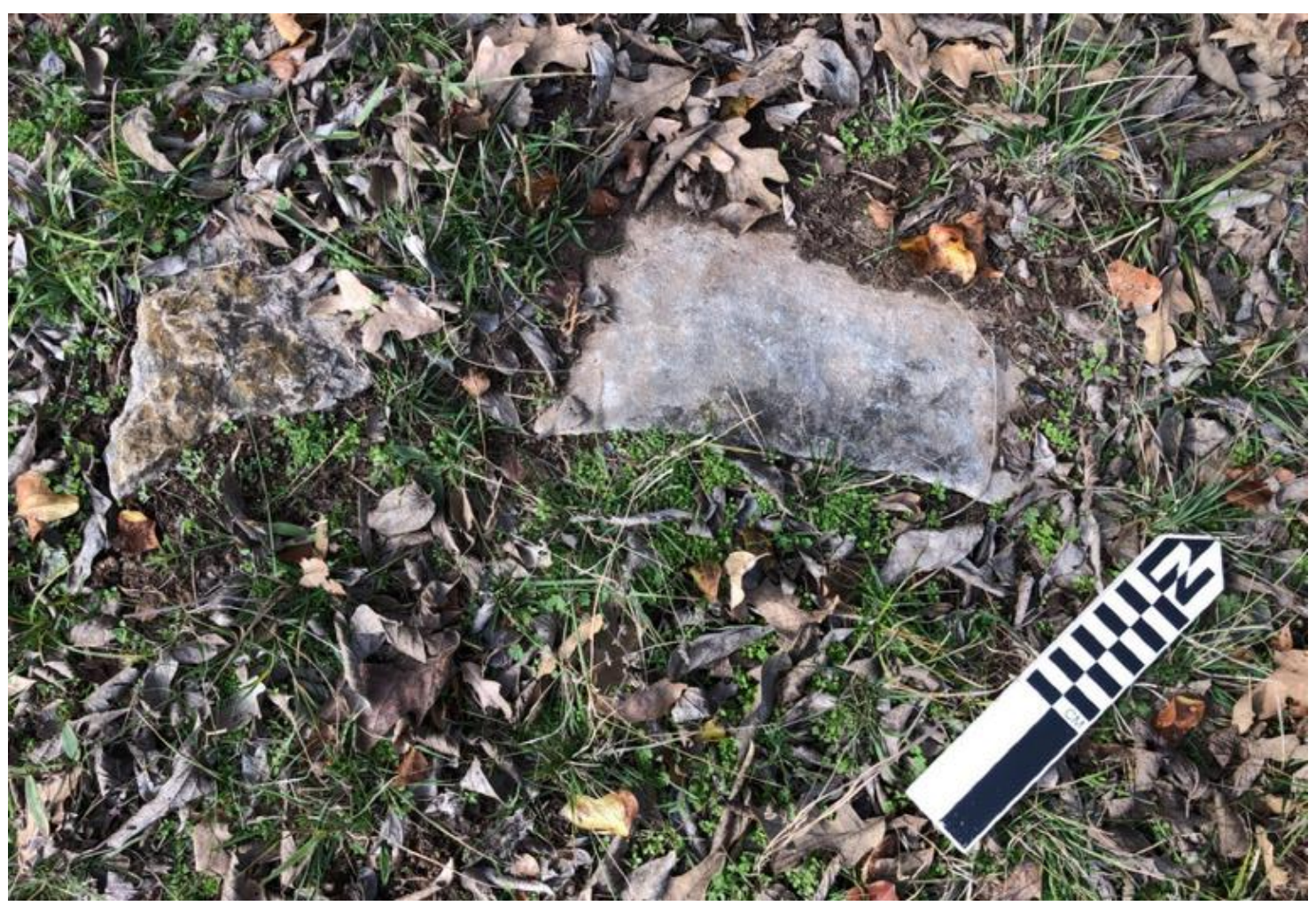

Figure 6-17 Possible cut stone feature near road, facing northwest. 


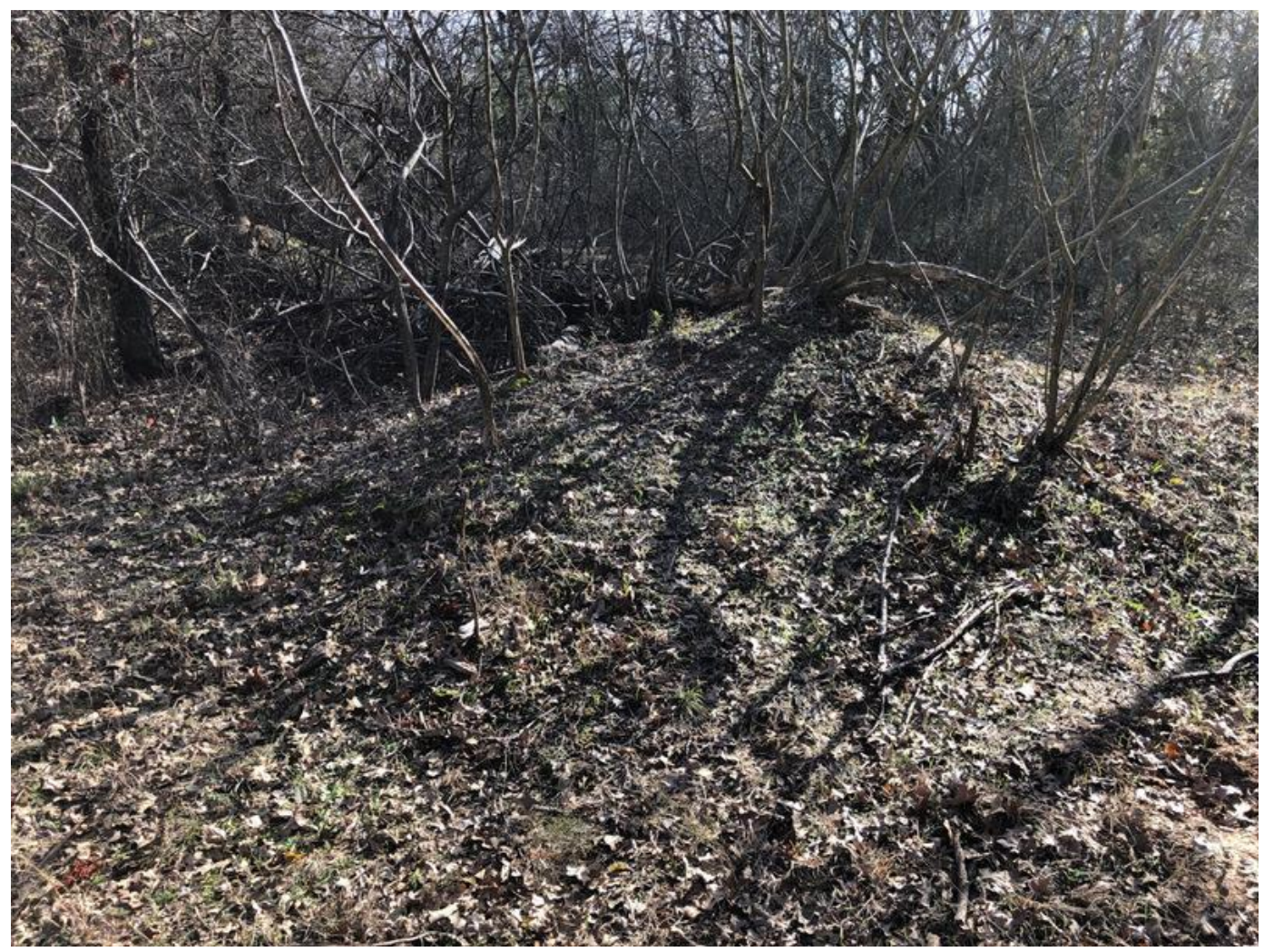

Figure 6-18 Push pile in sparse wooded area, facing southeast.

\section{WS160/08130800526}

Site 41WS160 is a small assemblage of historic cans and unknown metal artifacts. The site is located at the base of a western facing, eroded, gravel slope within the tree line to the west of a two-track road in the northern half of Unit 48 (Appendix D). It is situated in a relatively flat area in the mixed hardwood tree line. The geology consists of Early Cretaceous Antlers Sand. The 1967 Geologic Atlas of Texas, Sherman Sheet notes that Antlers Sand is commonly found in Eastern part of Trans-Pecos and High Plains and consists of sand, clay, and conglomerate. The lower and upper parts are mostly sand, middle part chiefly clay, and grades northward to interbedded sand and clay. Sand is fine to coarse grained, conglomeratic in lower part, clayey in upper part, and brownish-yellow. Conglomerate, chert, quartz, and quartzite are found as pebbles and granules. Thickness can be as much as $200 \mathrm{ft}$ but is variable because of the irregular surface on which it was deposited. The site was discovered during systematic shovel testing of LBJ National Grasslands Unit 48. It consists of a concentration of sanitary cans, oil cans and unknown metal fragments. A possible hearth/campfire is located within the area, but heavy leaf litter limited ground surface visibility (Figure 6-19). As shovel testing at the site 41WS160 noted no buried cultural deposits and historic cultural materials were observable on the ground surface, these boundaries were established by the mapping of the horizontal distribution of artifacts along the ground surface. No artifacts were collected, and any diagnostic artifacts were documented and photographed in situ (Figures 6-20 - 6-24). There is some modern sheet metal in association with the can assemblage. According to Horn (2005) the round oil cans were introduced in 1933. However, soft drinks were first canned in 1953. The $12 \mathrm{oz}$. cans featured a pull 
tab style opening first invented in 1962 and lasted until the late 1970s (Can Museum 2011). One can was labeled as Yukon Club Root Beer featuring a pull tab style top/opening. Yukon Club Root Beer cans are described as $355 \mathrm{~mL}$ (12 fl. oz.) steel bodied, pull top cans made in the United States. This particular can style was first issued in 1967. Noted impacts include natural erosion of the sloped are immediately east of the site as well as bullet holes in the cans indicating impacts from hunters. The cans and metal artifacts are heavily rusted, and oxidation will likely continue. There is also anecdotal evidence from hunters in the area that a hunting interest group occasionally does trash clean up within the Grasslands units and may constitute an unintentional, artificial impact. Because of the small number of commonly found historic materials and several natural and artificial disturbances, site $41 \mathrm{WS} 160$ has very limited research value and does not meet any of the criteria necessary for consideration as eligible for listing on the NRHP.
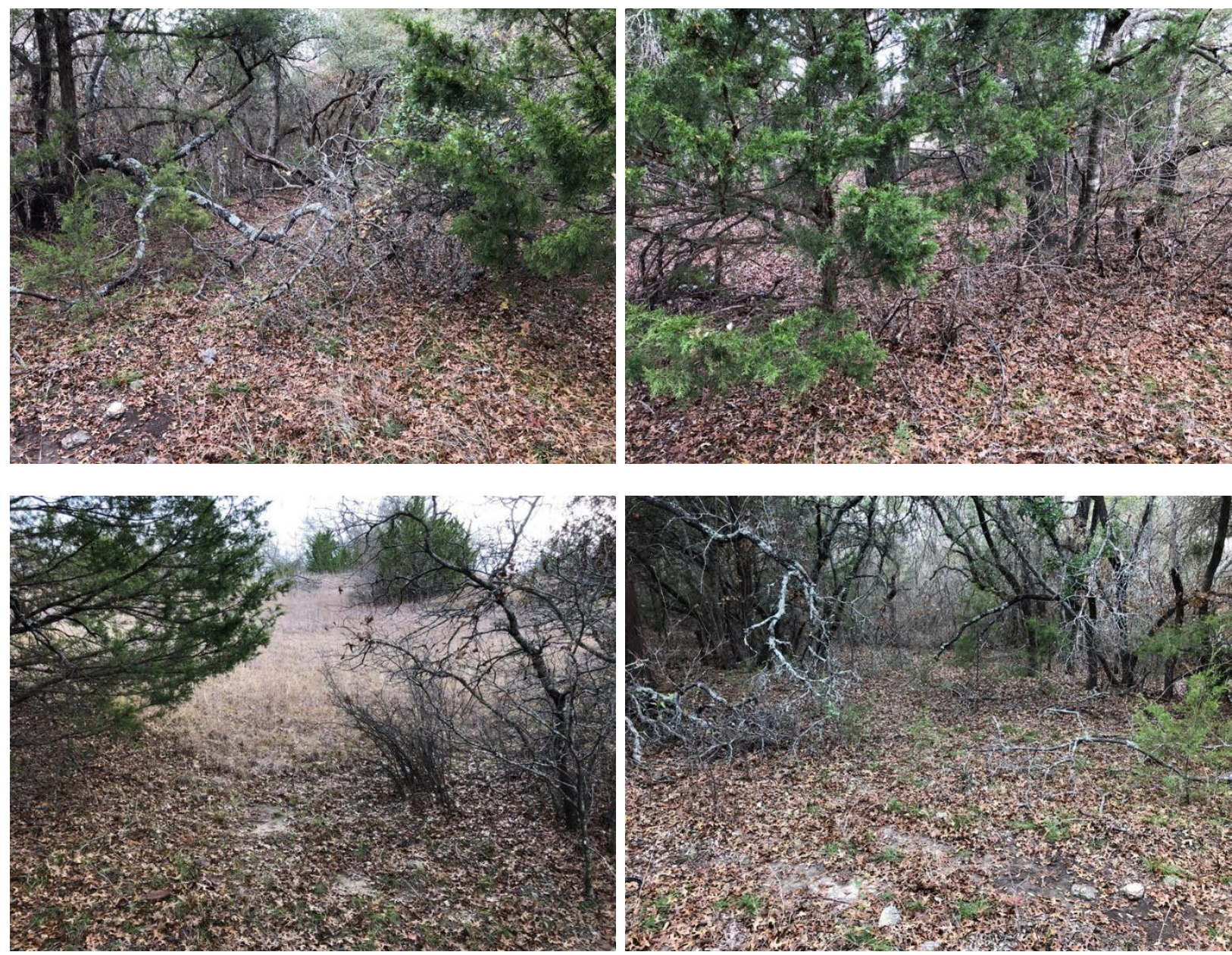

Figure 6-19 Overview of site 41WS160, facing north, east, south, and west (left to right). 


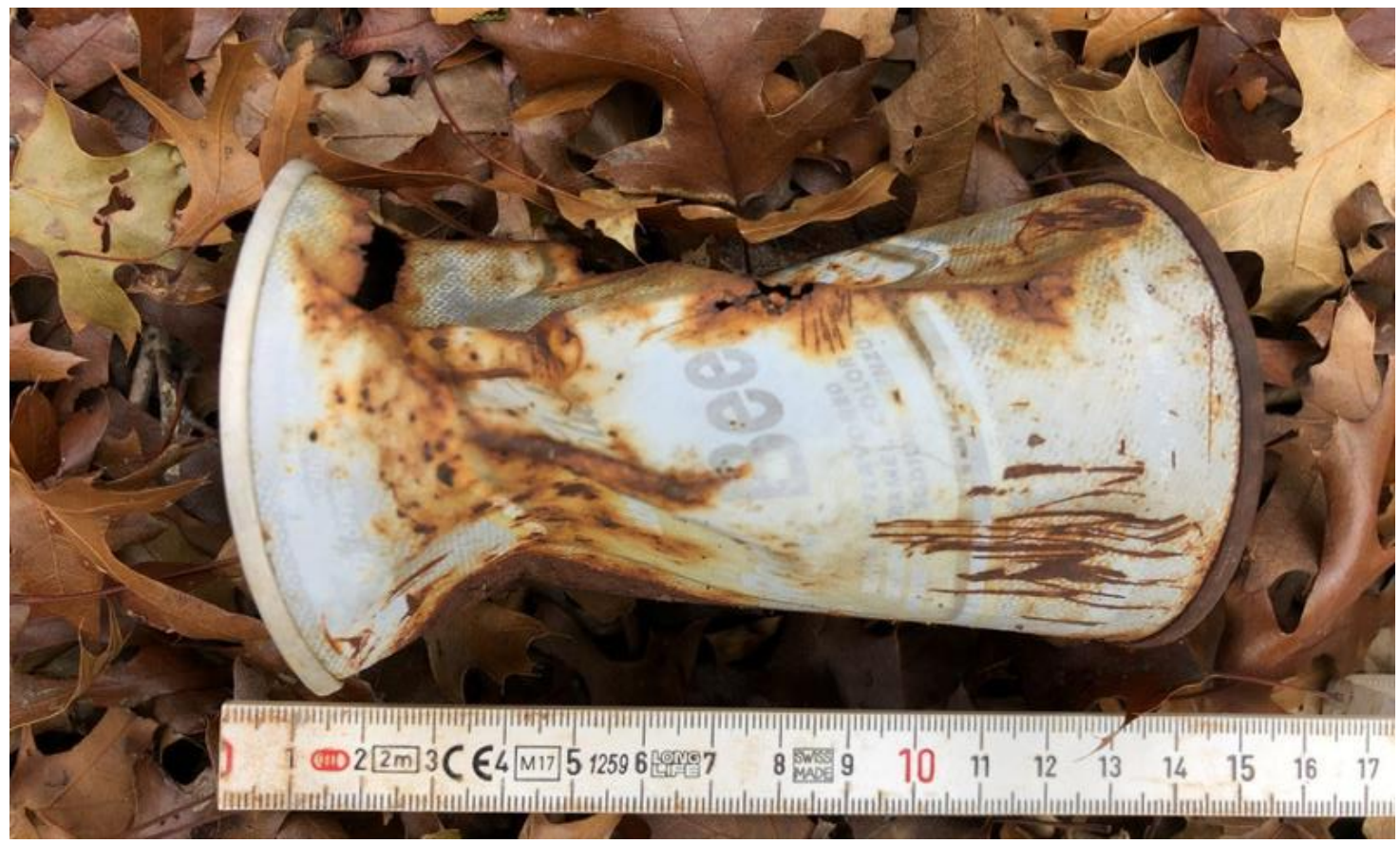

Figure 6-20 Yukon Club Root Beer can.

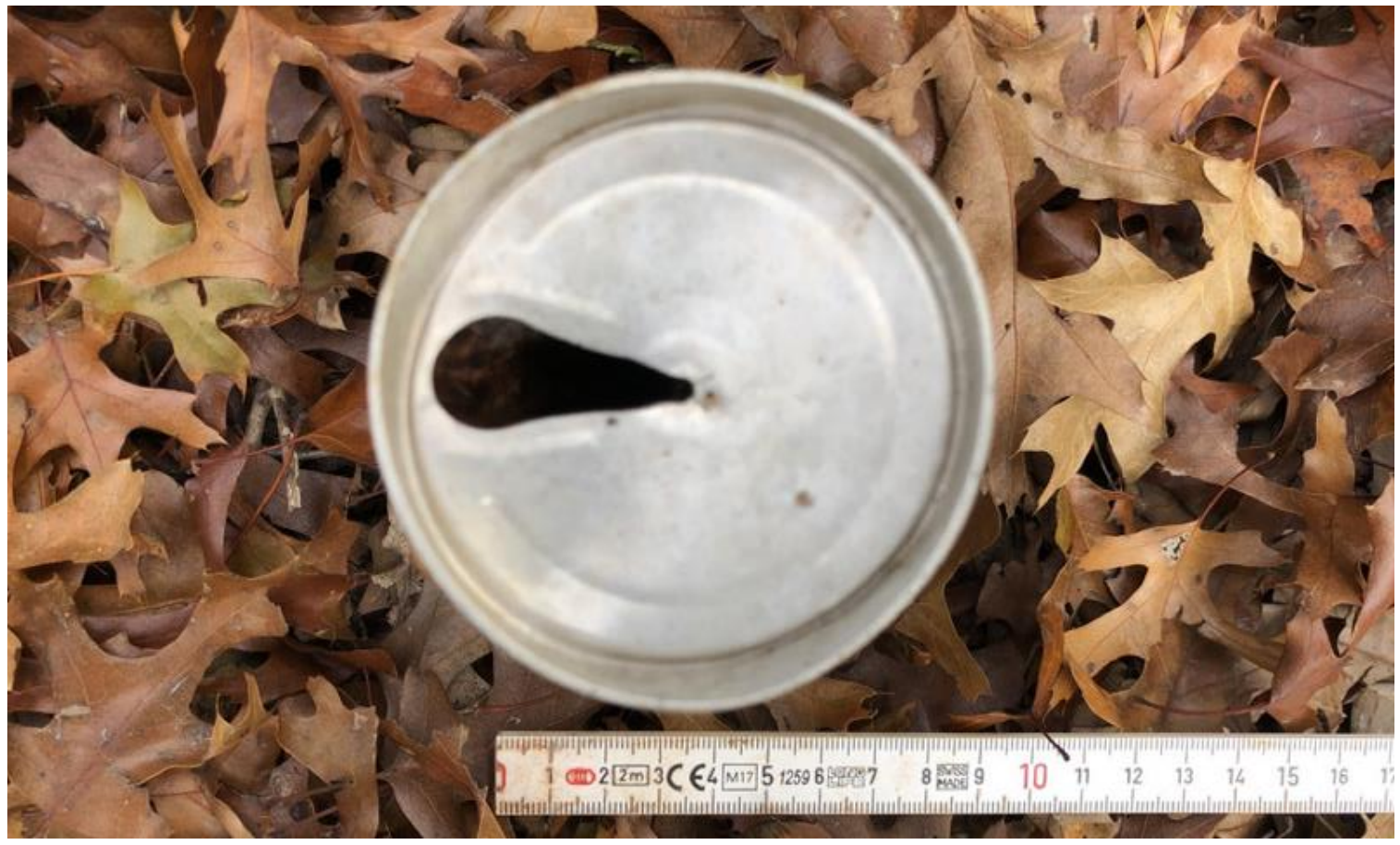

Figure 6-21 Pull top opening common to the sanitary cans found at 41WS160. 


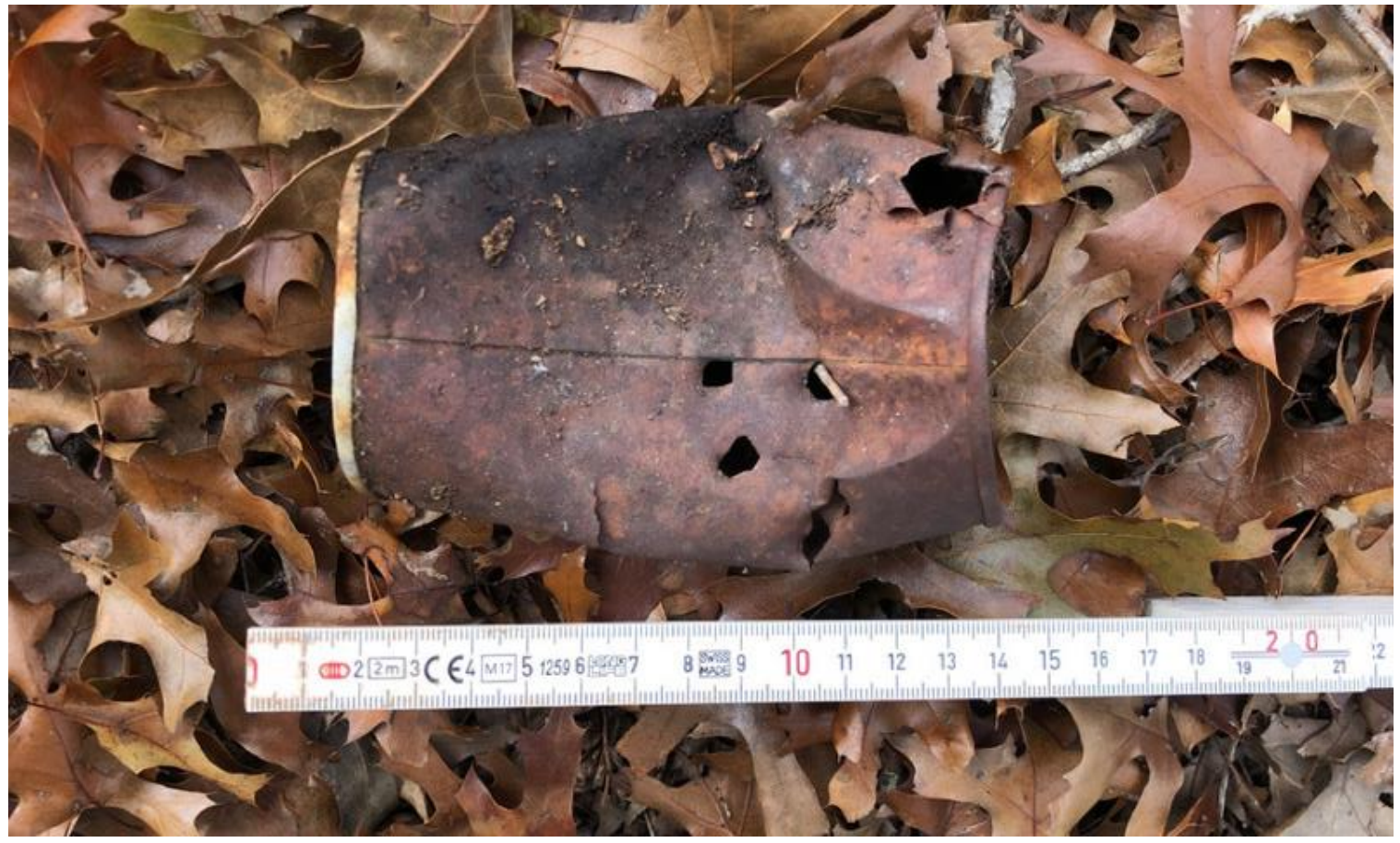

Figure 6-22 Heavily rusted sanitary can with evidence of bullet holes.

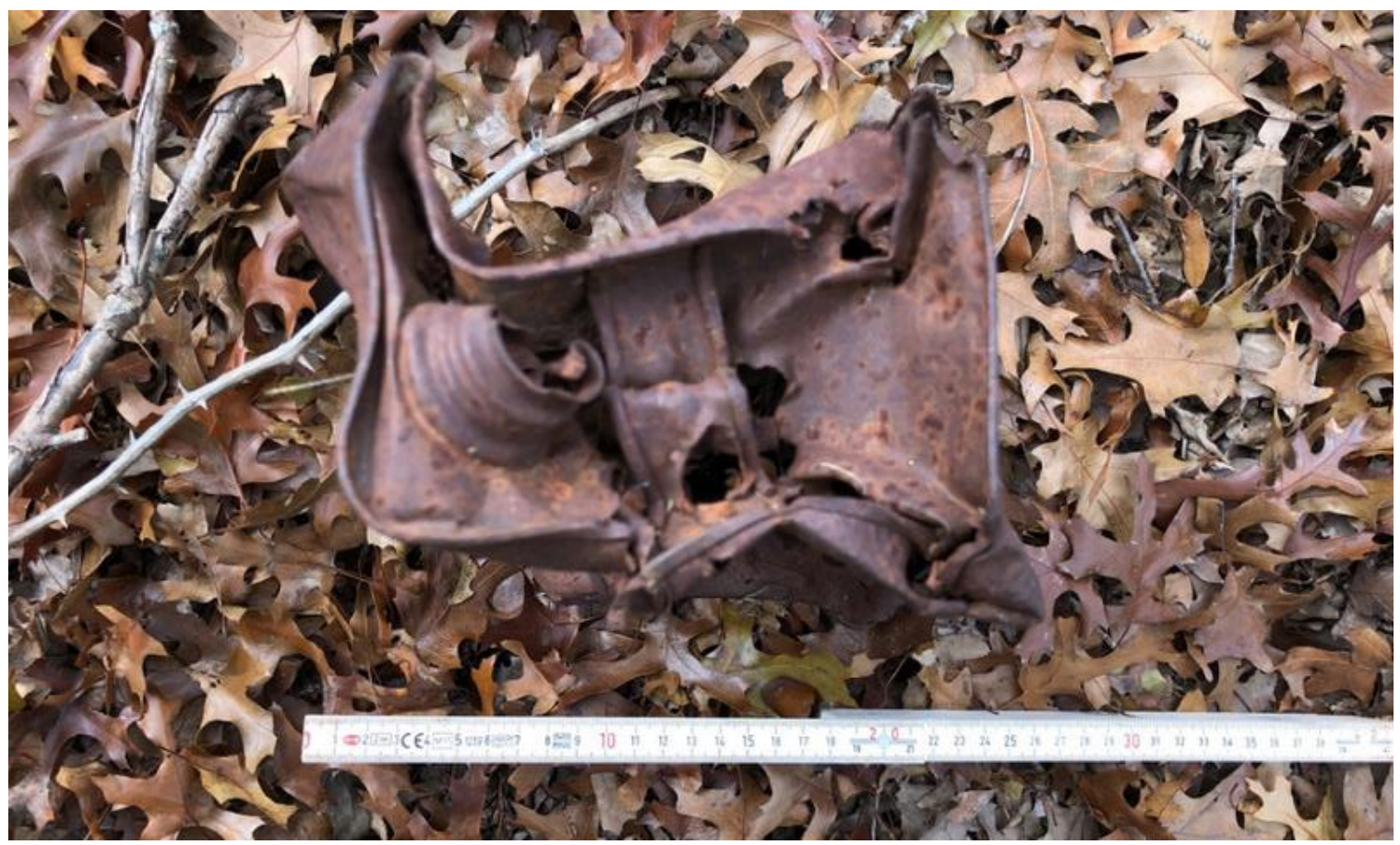

Figure 6-23 Rusted metal container found at 41WS160. 


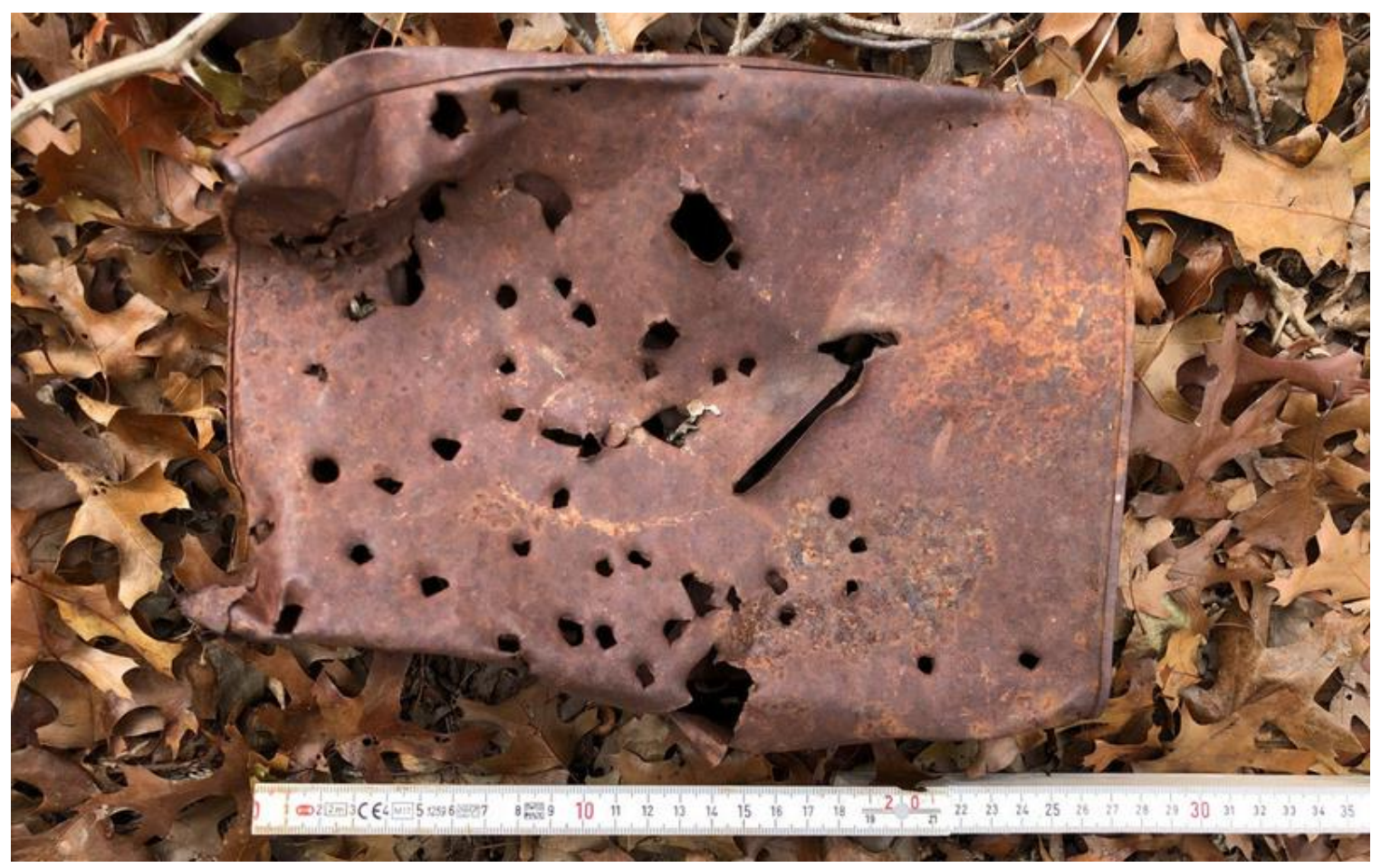

Figure 6-24 Side view of rusted container showing evidence of bullet holes. 


\section{WS161/08130800527}

Site $41 \mathrm{WS} 161$ is an assemblage of late $19^{\text {th }}$ or early $20^{\text {th }}$ century historic artifacts mixed with modern materials (Appendix D). Located northwest of and immediately adjacent to CR 2645, the site is in a sparse stand of mixed hardwood, young growth trees (Figure 6-25). There was some evidence of tree cutting and removal. Topographically, the area is uniformly flat. Open pasture is directly to the northwest of the sparse woodland. The geology consists of Early Cretaceous Antlers Sand. The 1967 Geologic Atlas of Texas, Sherman Sheet notes that Antlers Sand is commonly found in eastern part of Trans-Pecos and High Plains and consists of sand, clay, and conglomerate. The lower and upper parts are mostly sand, the middle part chiefly clay, and grades northward to interbedded sand and clay. Sand is fine to coarse grained, conglomeratic in lower part, clayey in upper part, and brownish-yellow. Conglomerate, chert, quartz, and quartzite are found as pebbles and granules. Thickness can be as much as $200 \mathrm{ft}$, but is variable because of the irregular surface on which it was deposited. The site was discovered during systematic shovel testing of LBJ National Grasslands Unit 62. The site appears to be a trash dump consisting of a concentration of recent historic and modern materials. The artifact assemblage includes bricks and cut stone, metal fragments, a fragmented stoneware crock, a plastic bottle, a plastic bag, and modern sheet metal (Figures 6-26-6-30). An active residence is located southwest of the site along CR 2645, and a storage shed is southeast of the site on the opposite side of County Road 2645. Shovel tests adjacent to the site were negative and indicated shallow, red, sandy clay loam/sandy clay subsoil at $40 \mathrm{cmbs}$ or less. The site was delineated based on the surface assemblage. Three fragments of a blue and gray stoneware utilitarian vessel, likely a crock, were found amongst the assemblage. One of the sherds is decorated with two parallel, cobalt blue bands that run the circumference of the crock. The lack of additional diagnostic characteristics makes precise dating difficult. It is likely a 19th to early 20th century utilitarian vessel. Additionally, a brick fragment is stamped with "DENT...FIRE B..." The brick fragment may be associated with the Denton Pressed Brick Company established in 1901 and later acquired by the Acme Brick Company in 1912 (Beck 2016). Noted impacts include natural erosion in a small number of areas and roadway construction towards the southeast where the site coincides with CR 2645. There is also anecdotal evidence from hunters in the area that a hunting interest group occasionally does trash clean up within the Grasslands units and may constitute an unintentional, artificial impact and loss of site resolution. Because of the small number of commonly found historic materials, the presence of modern materials, and several natural and artificial disturbances, site 41WS161 has very limited research value and does not meet any of the criteria necessary for consideration as eligible for listing on the NRHP. 

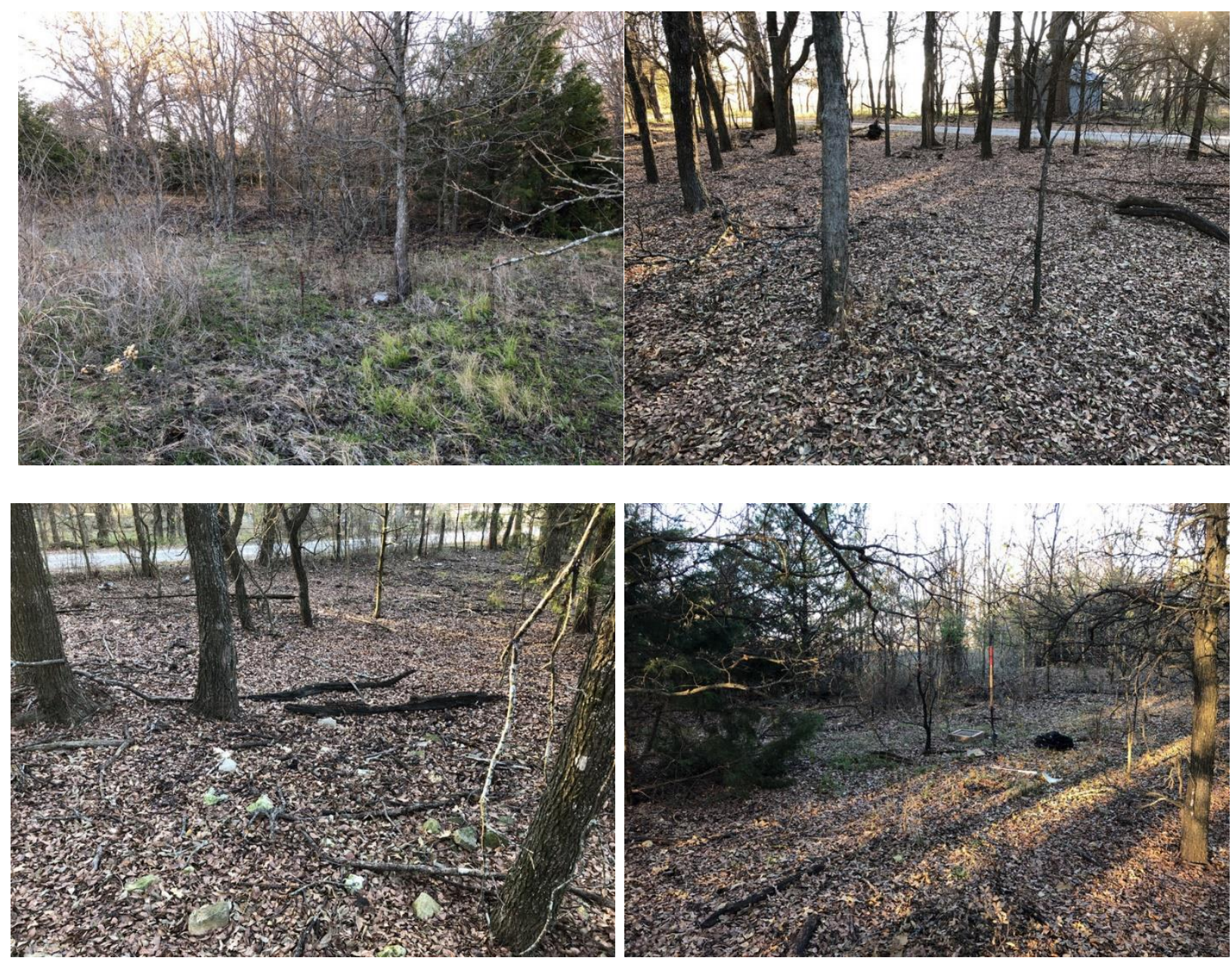

Figure 6-25 Overview of 41WS161, facing north, east, south, and west (left to right). 


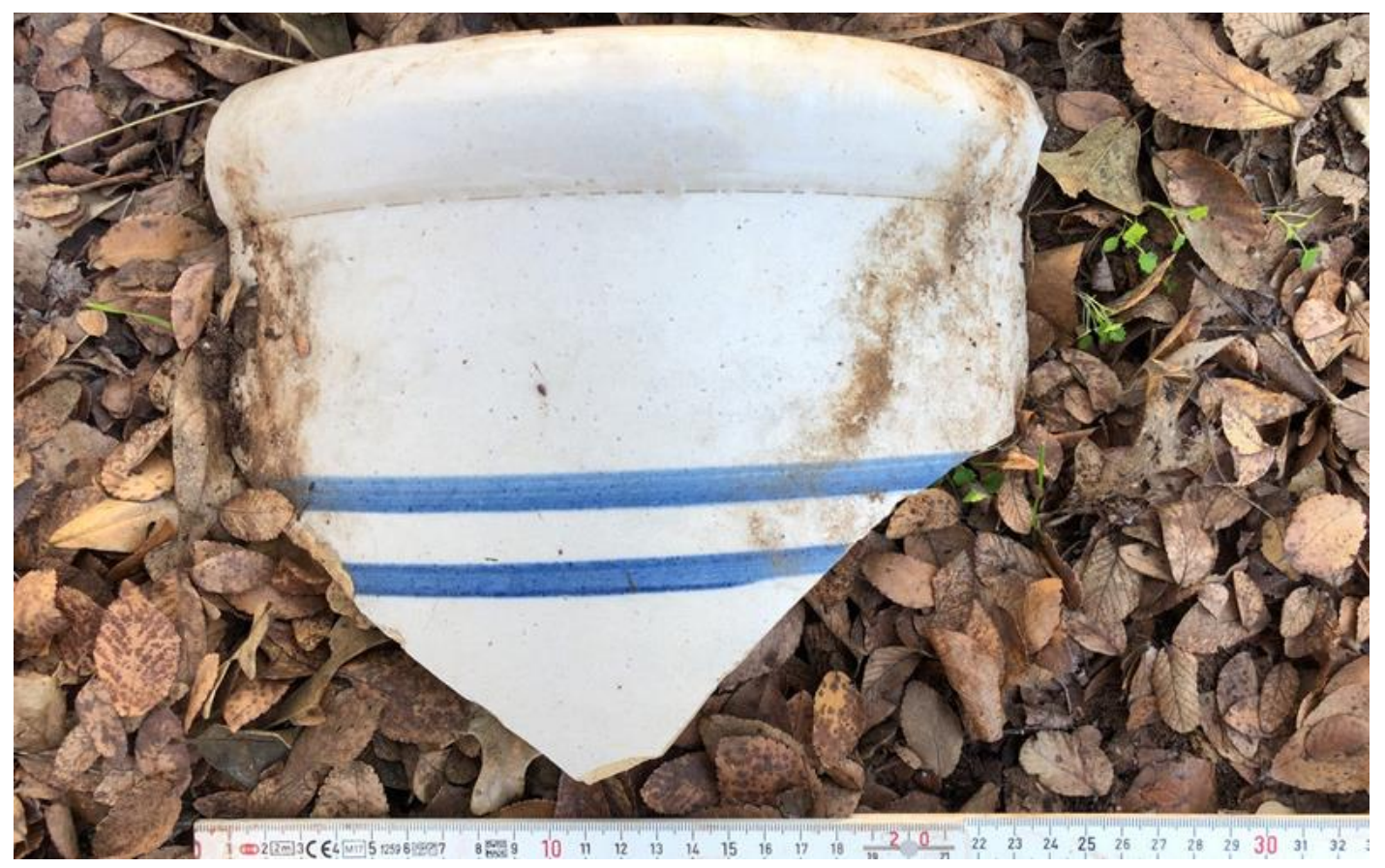

Figure 6-26 Fragment of blue banded stoneware crock at 41WS161.

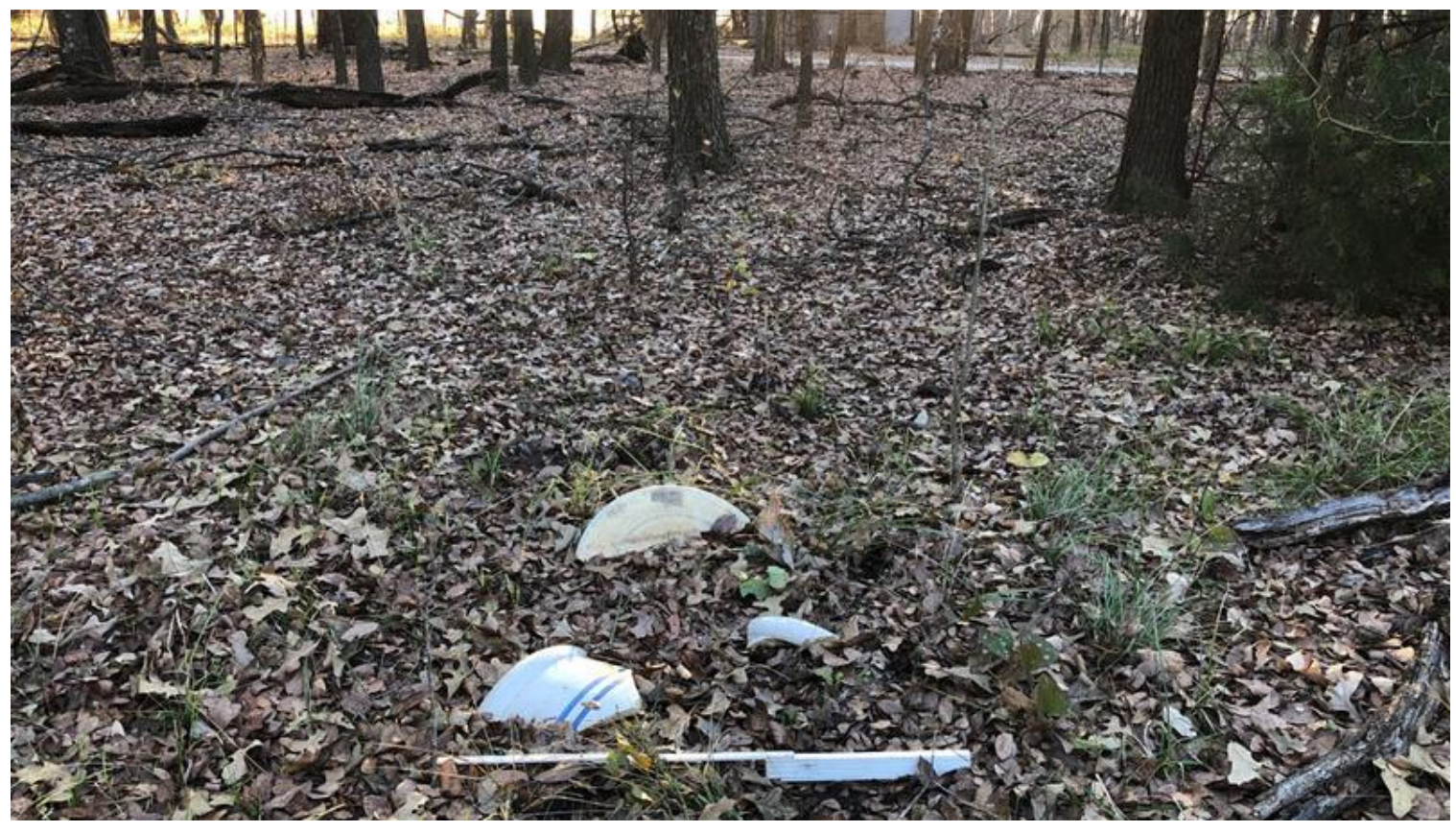

Figure 6-27 Overview of fragmented crock, facing southeast. 


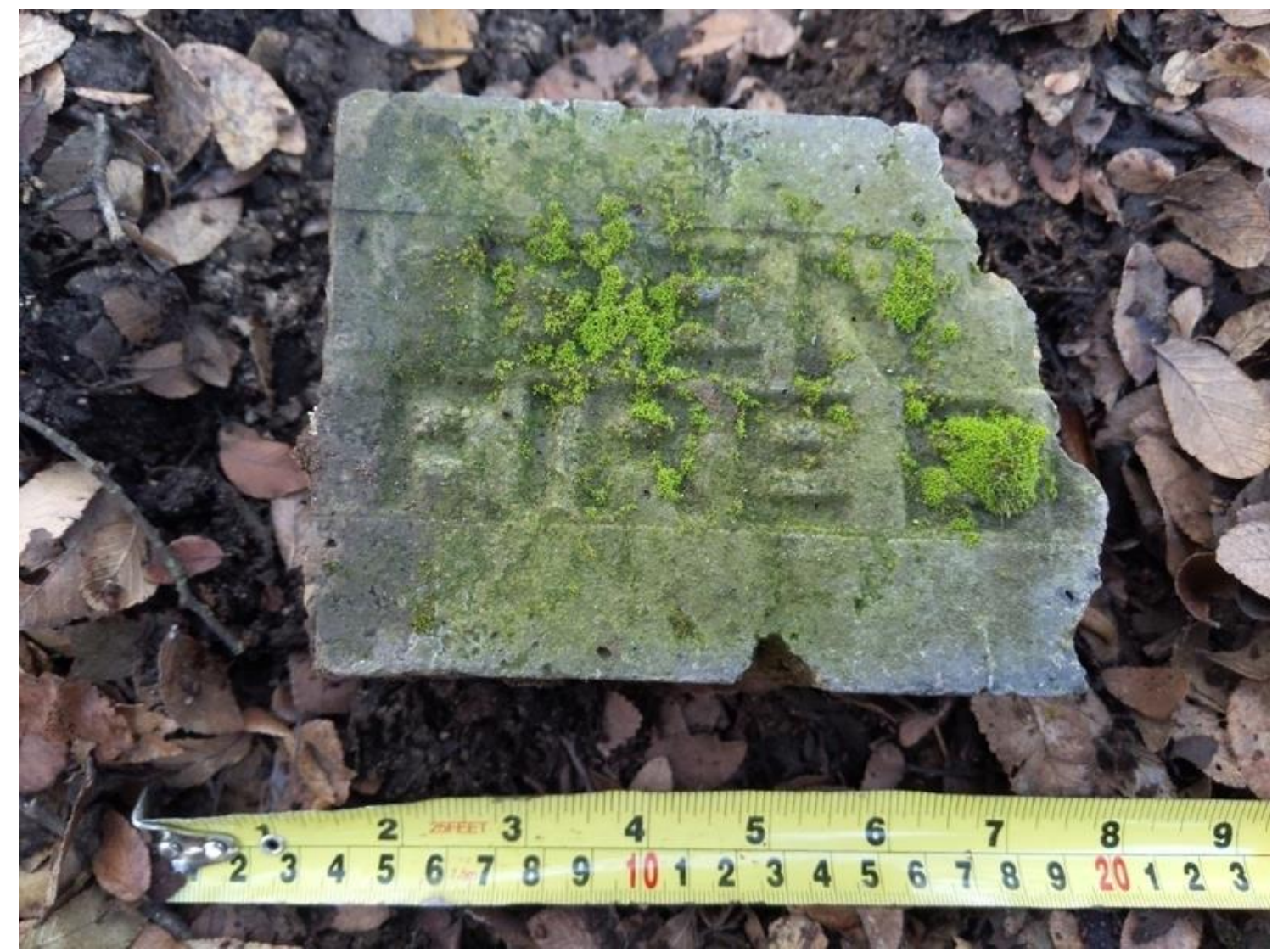

Figure 6-28 Brick with letters "DEN...FIRE...B" likely produced by Denton Pressed Brick Company.

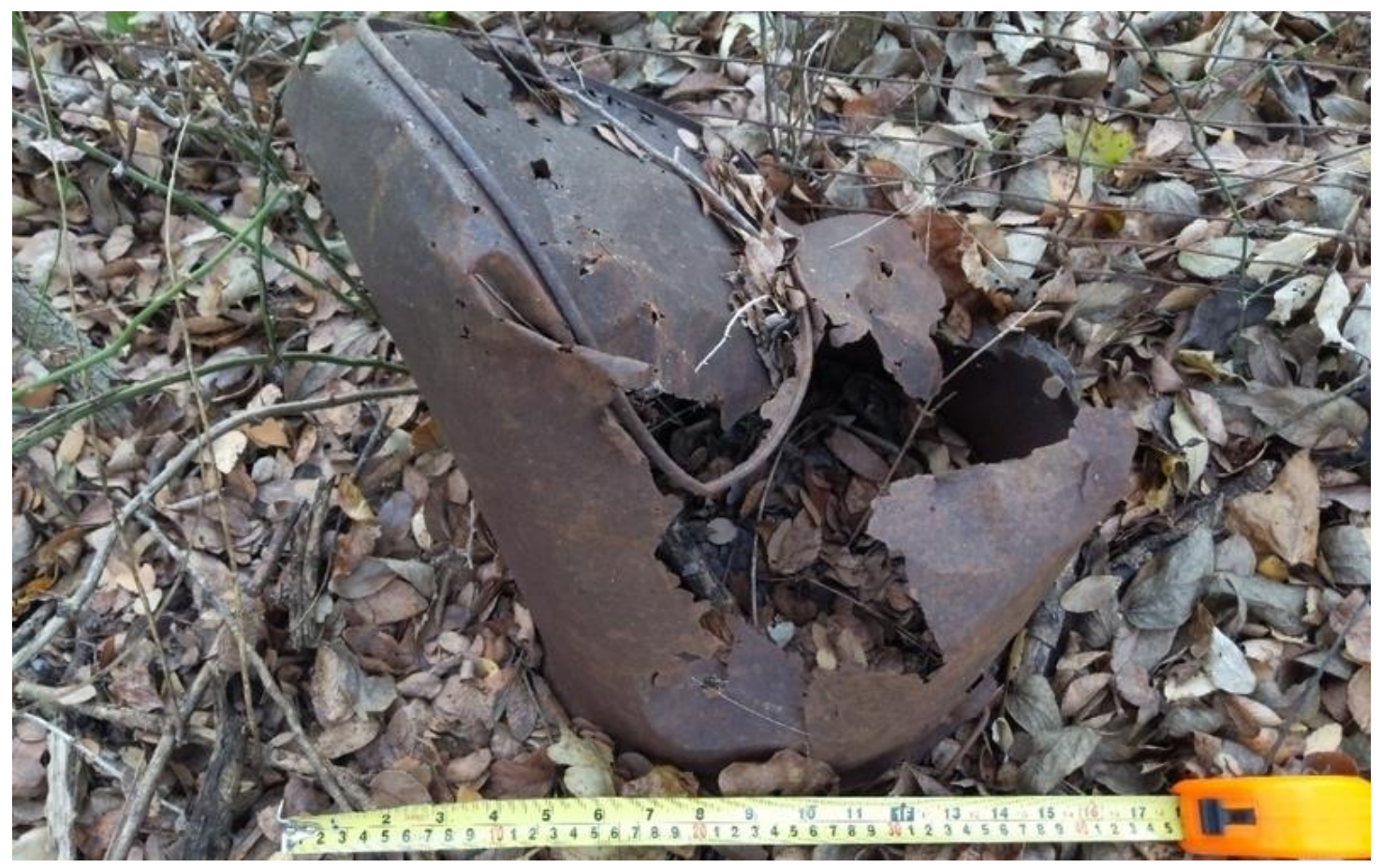

Figure 6-29 Unknown metal container, facing southeast. 


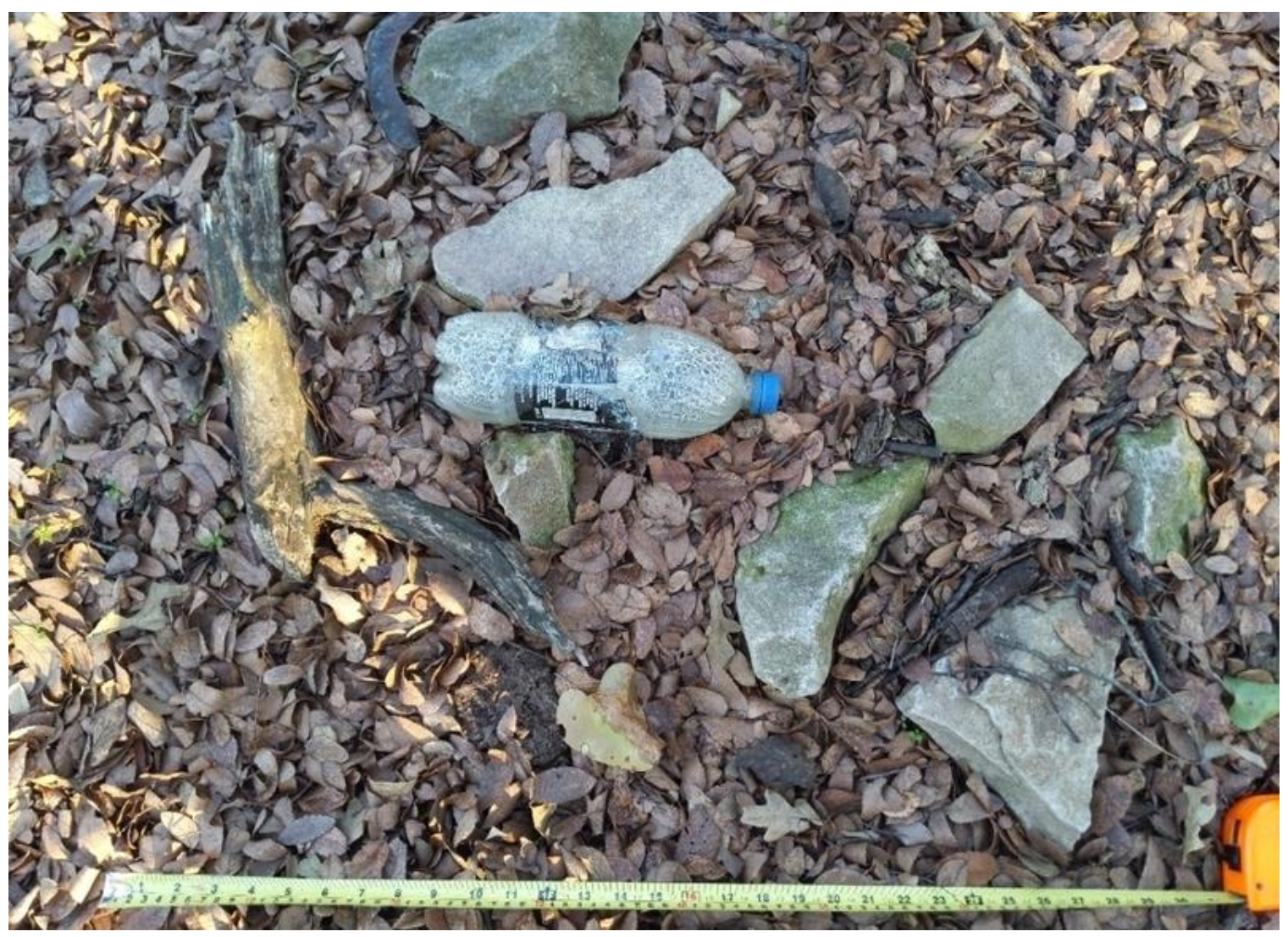

Figure 6-30 Evidence of modern materials deposited and intermixed with historic materials.

\section{Isolated Feature - Windmill}

An isolated feature, a galvanized steel framed windmill, was found along the northeast side of the northwest-southeast running CR 2648 within the boundaries of Unit 63 (Appendix D). Directly adjacent to the windmill was a galvanized steel modern stock tank (Figures 6-31-6-35). The windmill is located within a sparse stand of mixed hardwood, young growth trees. The area immediately surrounding the windmill and stock tank had been cleared of trees and the windmill built on a slightly raised, graded surface approximately $7 \mathrm{~m}$ in diameter. Shovel testing adjacent to the isolated feature were negative for cultural features. The galvanized stock tank is labeled Farmaster and was a modern manufacturer of a various farm equipment headquartered in Columbus, NE. The company merged with Behlen Manufacturing Company in 1983 according to the company's history (Behlen Manufacturing 2019). Metal frame windmills span a broad range of time being first developed in 1876, increasing in popularity by the 1890s and declining in use over the course of the 1930s, 40s, and 50s as alternate technology was developed (National Park Service 2019). However, windmills for pumping water are still being used by small farms across the Great Plains. Given the presence of the Farmaster stock tank, it is likely that the windmill was constructed between the mid to late $20^{\text {th }}$ century. The galvanized steel windmill is a common design throughout the rural United States and has very limited research value and does not meet any of the criteria necessary for consideration as eligible for listing on the NRHP. 


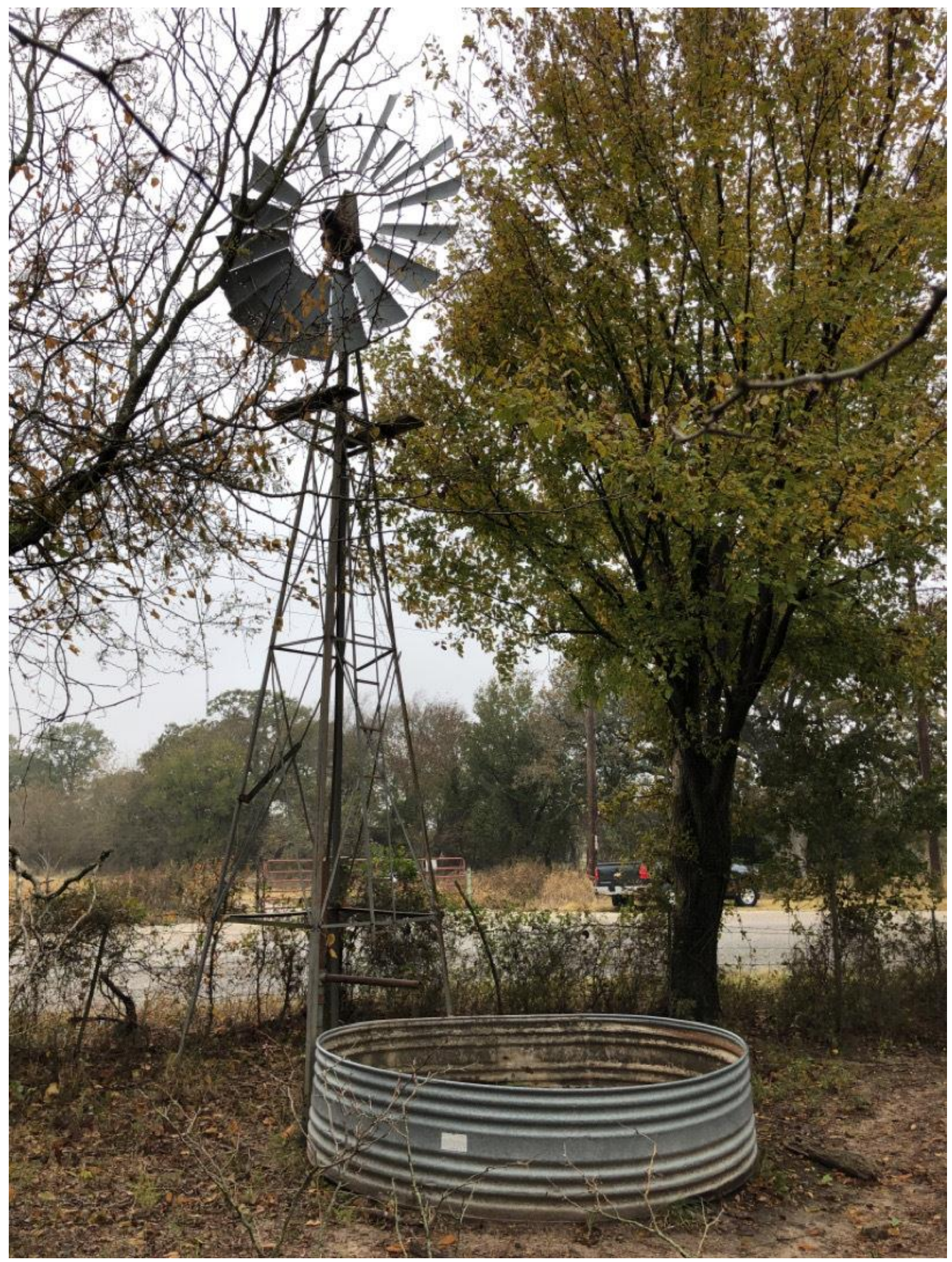

Figure 6-31 Overview of windmill and modern galvanized stock tank, facing northwest. 


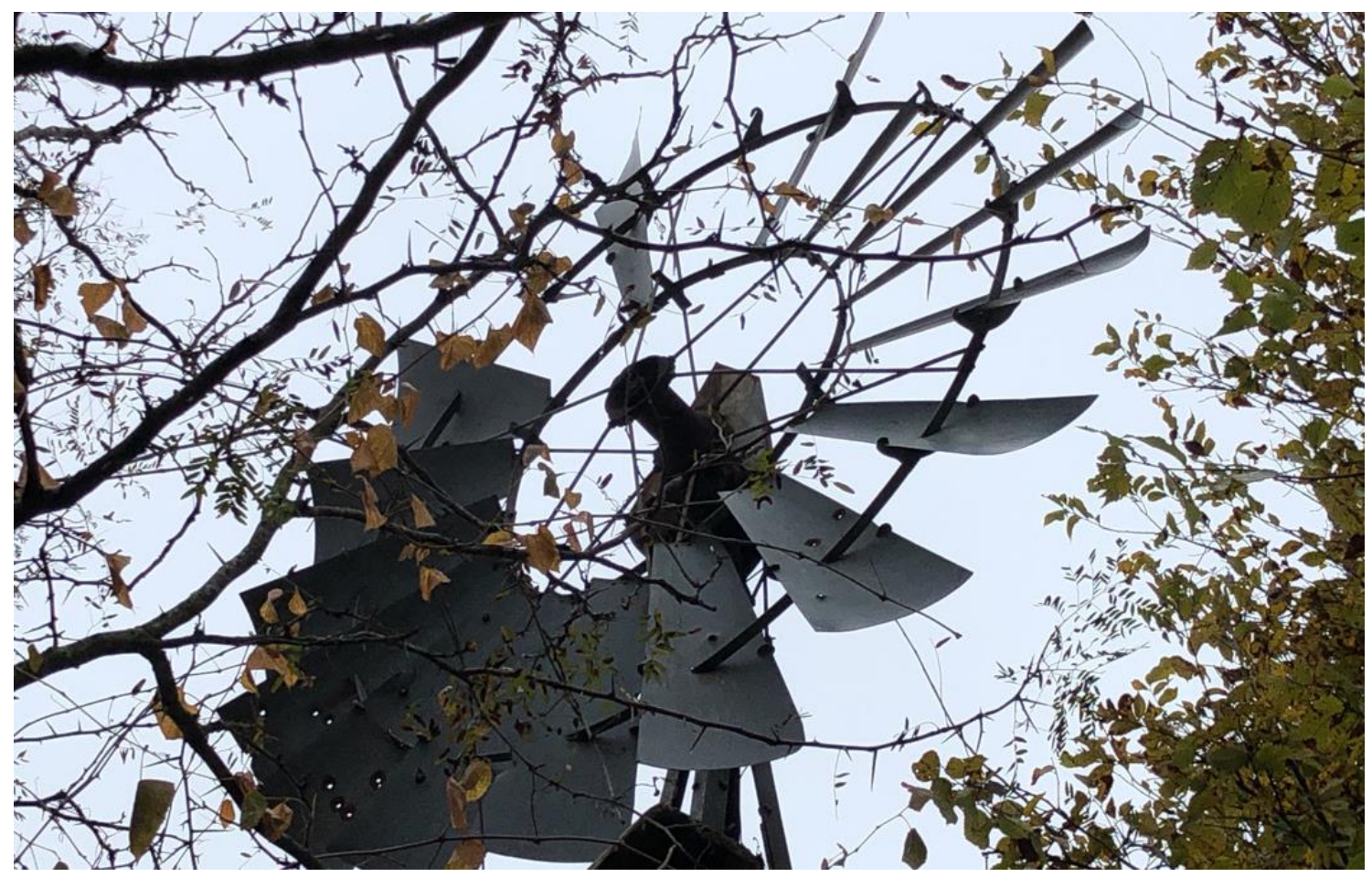

Figure 6-32 Close up of windmill head and blades, facing northwest.

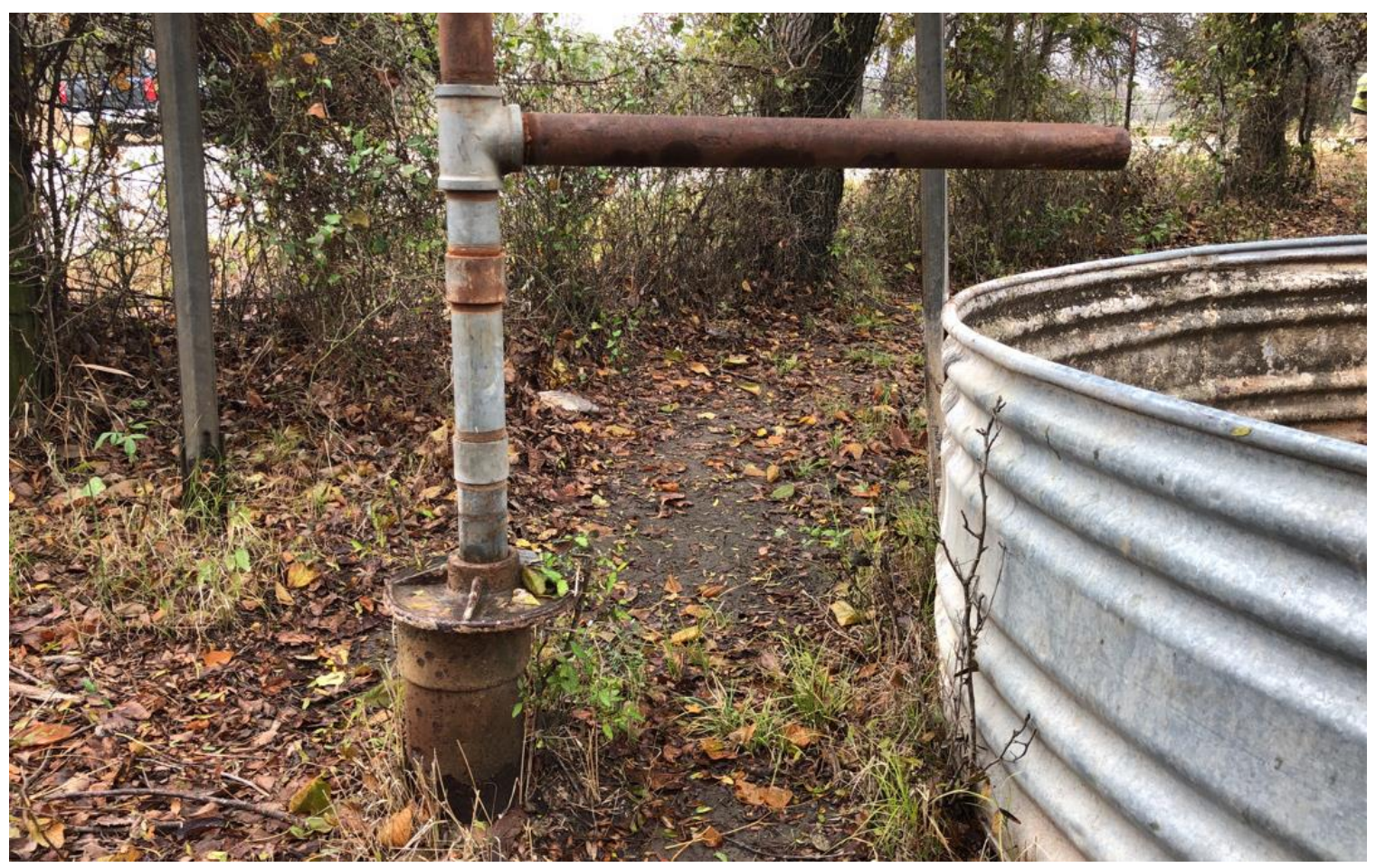

Figure 6-33 Metal piping without output to the stock tank, facing northwest. 


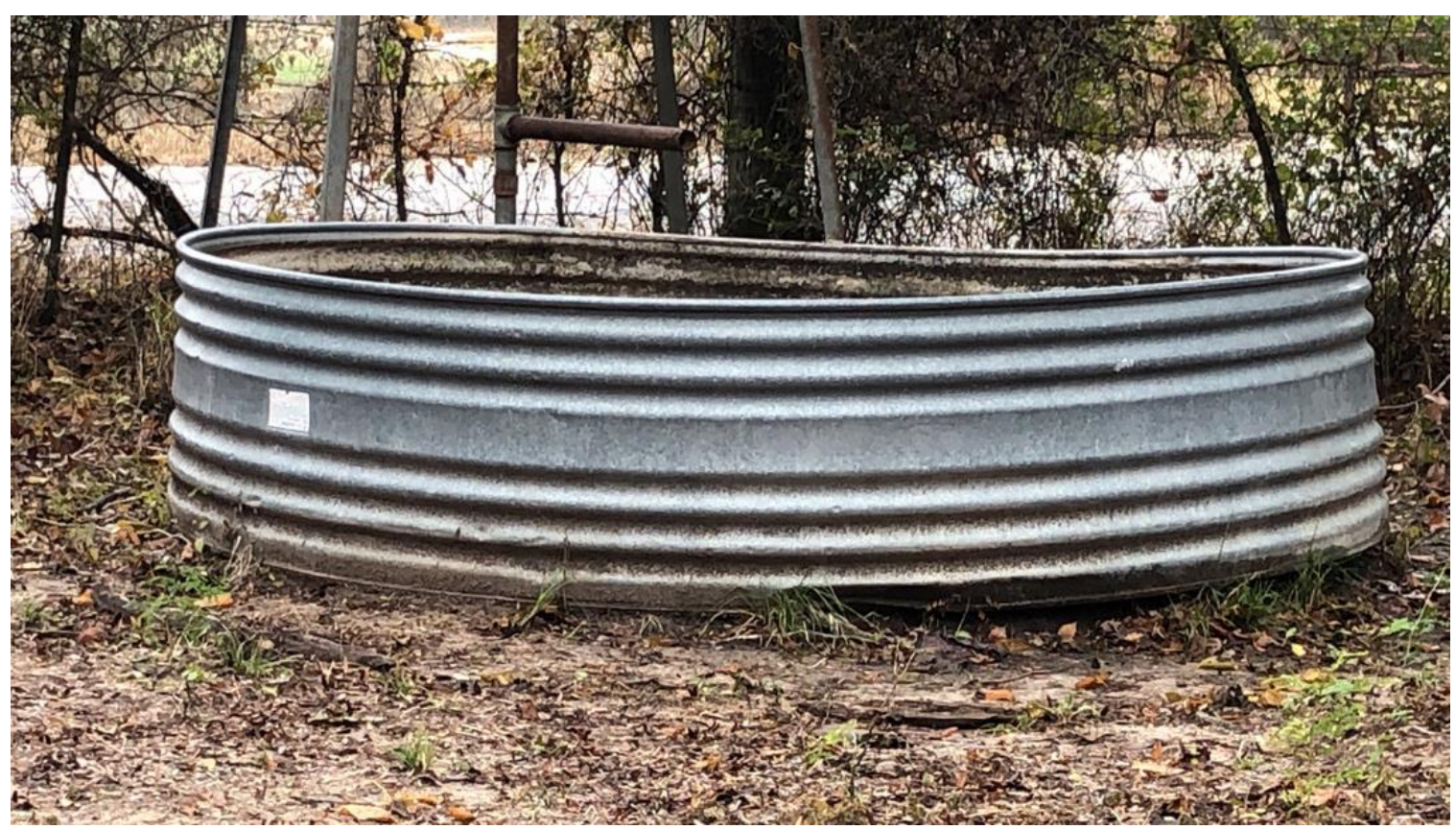

Figure 6-34 Galvanized steel stock tank, facing southwest.

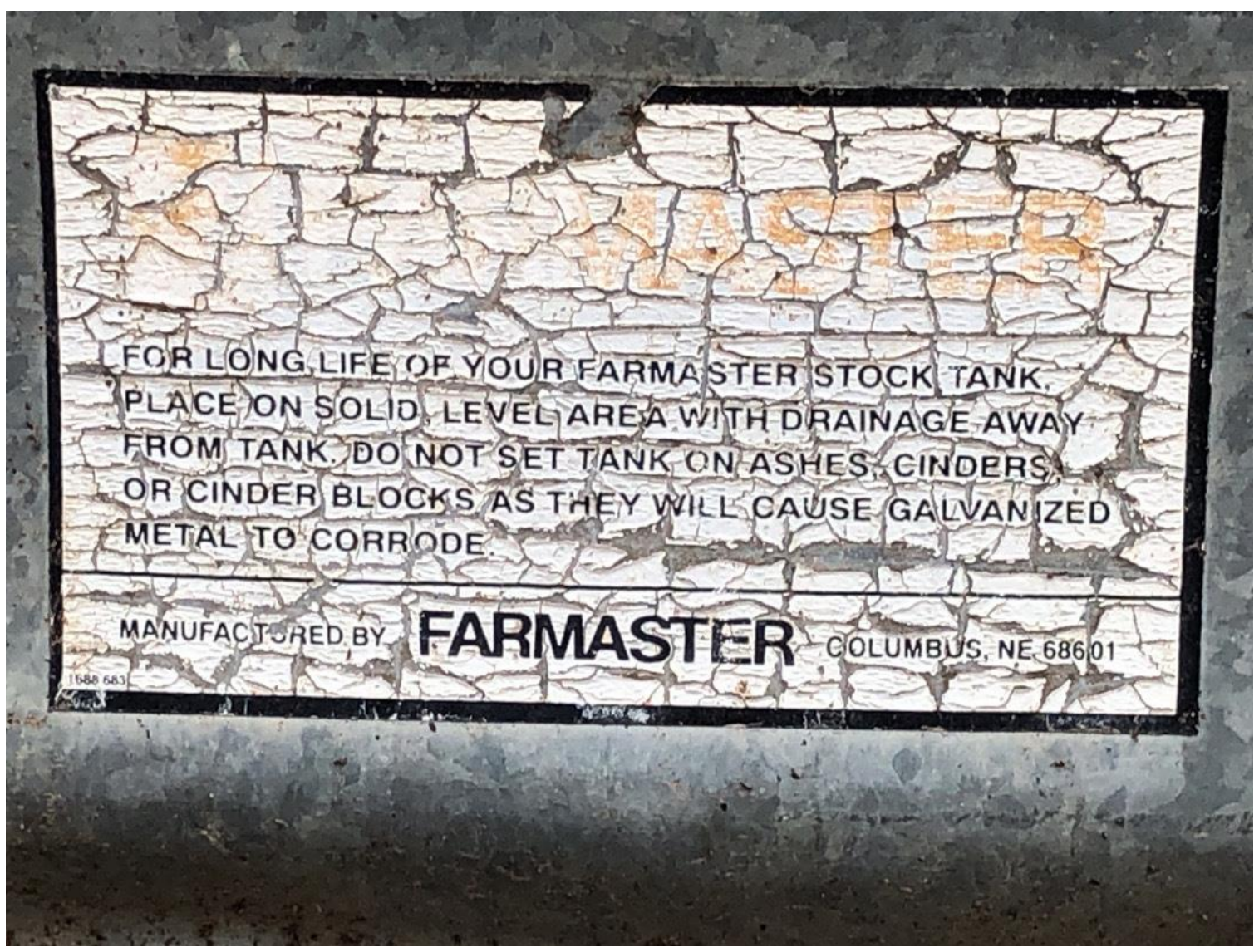

Figure 6-35 Farmaster label on stock tank, facing southeast. 
Cultural Resources Survey and Evaluation of Archeological Sites 41WS105, 41WS159, 41WS160, and 41WS161 for the Proposed Fence Line Project in Grasslands Units 48, 62, and 63, LBJ National Grassland, Wise County, Texas

This page intentionally left blank. 


\subsection{PROJECT SUMMARY AND RECOMMENDATIONS}

The USFS is proposing to reconstruct perimeter fencing surrounding three Grasslands units located within the LBJ National Grassland in Wise County, Texas as implementation of the LBJ Prairie Savanna Restoration Project. This project is necessary to create a 40 -foot fireline around LBJ National Grasslands units as these units are overgrown with dense vegetation and have limited to no mobility through them, posing a wildfire hazard. Impacts entail bulldozing to clear these perimeters of all trees and other woody vegetation, both above and below ground and new fence construction including utilization of metal tposts and the use of an auger to drill into the ground to set metal corner posts and concrete bracing. As part of the proposed perimeter fence reconstruction, the USFS has contracted with TRC to perform an inventory of cultural resources within three proposed Grasslands units (Units 48, 62, and 63) which includes background and historic research, archeological field survey, site delineation, a determination of the condition of recorded cultural resources, and recommendation of eligibility for listing on the NRHP).

\subsection{Project Recommendations}

A background review prior to fieldwork depicted no recorded SALs, NRHP-eligible or listed properties, or cemeteries located within or adjacent to the APE. TRC archeologists performed systematic shovel testing, pedestrian survey, and visual inspection at three Grasslands units (Units 48, 62, and 63) on October 31November 8 and December $4-6,2019$. During the investigations, a total of 477 shovel tests were recorded across the APE including No Dig shovel tests. Six shovel tests were positive for cultural materials. Three new sites were recorded within the APE and an extension to previously recorded site $41 \mathrm{WS} 105$ was delineated as a result of the survey. While the revisit of $41 \mathrm{WS} 105$ resulted in a small number of additional lithic artifacts, it did not yield any diagnostic artifacts that would indicate a specific temporal or cultural affiliation. The three new sites, 41WS159, 41WS160, and 41WS161, consist of historic cultural materials ranging between the late $19^{\text {th }}$ to the middle part of the $20^{\text {th }}$ century. In the case of 41WS161, there were a number of modern materials intermixed with the historic assemblage. In each case, there was evidence of a combination of natural and artificial impacts affecting the integrity of the assemblages. Boundaries for the 41WS105 extension and 41 WS159 were based on both the distribution of positive shovel tests and the presence of cultural materials on the ground surface. As shovel testing at two of the new sites, 41WS160 and 41WS161, noted no buried cultural deposits and historic cultural materials were observable on the ground surface, these boundaries were established by the mapping of the horizontal distribution of artifacts along the ground surface. During the investigations an isolated historic windmill with an adjacent modern galvanized steel stock tank was encountered within Unit 63 . The galvanized steel windmill is a common design throughout the rural United States and has very limited research value and does not meet any of the criteria necessary for consideration as eligible for listing on the NRHP. Based on the results of the survey, TRC recommends that no further investigations are necessary, and the project may proceed as planned.

In the event that any human or potential human remains are encountered during construction activities, all work should cease immediately in that specific area and the contractor shall notify local law enforcement, who in turn shall notify the local medical examiner's office. If these remains are not considered recent by the medical officer (i.e., most likely prehistoric in age), then TRC archeologists should be notified and THC contacted. 
Cultural Resources Survey and Evaluation of Archeological Sites 41WS105, 41WS159, 41WS160, and 41WS161 for the Proposed Fence Line Project in Grasslands Units 48, 62, and 63, LBJ National Grassland, Wise County, Texas

This page intentionally left blank. 


\section{REFERENCES}

Beck, B.

2016 Acme Brick Company: 125 Years Across Three Centuries. The Donning Company Publishers. Virginia Beach, VA.

Behlen Manufacturing

2019 Acquisitions. Electronic document. https://www.behlenmfg.com/acquisitions, accessed December 2019.

Blair, W. F.

1950 Biotic Provinces of Texas. The Texas Journal of Science 2(1):93-117.

Byers, Johnny A.

2007 The Geologic and Archaeological History of the Dickie Carr Site 41PR26. MA thesis, University of North Texas, Denton, Texas.

Can Museum

2011 Yukon Club Root Beer 355mL United States. Electronic document. http://www.canmuseum.com/Detail.aspx?CanID=34253, accessed December 2019.

Conner, Seymour V.

1959 The Peters Colony of Texas: A History and Bibliographical Sketch of the Early Settlers. The Texas State Historical Association, Austin.

Ferring, C.R. 1

1989a The Aubrey Site: A Clovis Occupation Site on the Southern Plains. In Abstracts of the First World Summit Conference on the Peopling of the Americas, edited by J. Tomenchuk and R. Bonnichsen, p. 20 Orono: Center for the study of the First Americans, University of Maine.

1989b The Aubrey Site: A Paleo-Indian Locality in the Upper Trinity River Basin, Texas. Current Research in the Pleistocene 6:9-11.

1990 Archeological geology of the Southern Plains. In Archaeological Geology of North America, edited by N.P. Lasca and J. Donahue, pp. 253-266. Geological Society of America, Centennial Special Volume 4, Boulder Colorado.

1995 Subsistence and Mobility Patterns at the Aubrey Clovis Site, Texas. Abstracts of the $60^{\text {th }}$ Annual Meeting of the Society for American Archaeology, pp. 74-75. Minneapolis, Minn.

Ferring, C.R. and B.C.Yates

1997 Holocene Geoarchaeology and prehistory of the Ray Roberts Lake Area, North Central Texas.Institute of Applied Sciences, University of North Texas, Denton.

Gould, F.W., G.O. Hoffman, and C.A. Rechenthin

1960 Vegetational Areas of Texas. Leaflet 492. Texas Agricultural Experiment Station, College Station, Texas. 
Horn, J.

2005 Historic Artifact Handbook. Alpine Archaeological Consultants, Inc. Montrose, CO.

Jurney, David H., Frank Winchell, and Randall W. Moir

1989 Cultural Resources Overview of the National Grasslands in North Texas: Studies in Predictive Archaeological Modeling for the Caddo and LBJ Grasslands. Archaeology Research Program, Institute for the Study of Earth and Man, Southern Methodist University.

Johnson, Eileen

1987 Cultural Activities and Interactions. In Lubbock Lake: Late Quaternary Studies on the Southern High Plains, edited by E. Johnson, pp.120-158. Texas A\&M University Press, College Station.

Kreiger, A.D.

1946 Culture Complex and Chronologies in Northern Texas. University of Texas Publication No. 4640, Austin.

Meining, D.W.

1969 Imperial Texas: An Interpretive Essay in Cultural Geography. The University of Texas Press.

Meltzer, D.J.

1987 The Clovis Paleoindian Occupation of Texas: Results of the Texas Clovis Fluted Point Survey. Bulletin of the Texas Archeological Society 57:27-68.

National Park Service

2019 Windmills of the American Plains. Electronic document, https://www.nps.gov/articles/windmills.htm, accessed December 2019.

Peter, Duane and James Harrison

2011 Archaeological Data Recovery (41TR198) and Survey within the Riverside Oxbow Project, Tarrant County, Texas. Geomarine, Incorporated. Plano, Texas.

Pressler, H. \& Texas.

1895 Map of Wise County. [Austin, Tex.: General Land Office] [Map] Retrieved from the Library of Congress, https://www.loc.gov/item/2012592136/, accessed December 2019.

Prewitt, Elton R.

1981 Cultural Chronology in Central Texas. Bulletin of the Texas Archeological Society 52:65-90.

Prikryl, D.J. 1

1990 Lower Elm Fork Prehistory, A Redefinition of Cultural Concepts and Chronologies Along the Trinity River, North-Central Texas. Office of the State Archeologist Report 37. Texas Historical Commission, Austin.

Soil Survey Staff

2015 Web Soil Survey. Electronic document, http://websoilsurvey.nrcs.usda.gov/app/WebSoilSurvey.aspx, accessed October 2019. 
Shaddox, L. and J. Hall

2010 41WS105 Archeological Site Form (Atlas \#9497010501). Texas Archeological Sites Atlas. Electronic document. https://atlas.thc.state.tx.us/Account/Login, accessed November 2019.

Stanford, Dennis J.

1982 A Critical Review of Archeological Evidence Relating to the Antiquity of Human Occupation of the New World. In Plains Indians Studies: A Collection of Essays in Honor of John C. Ewers and Waldo Wedel, edited by D.H. Ubelaker and H.J. Viola, pp. 208-218. Smithsonian Contributions to Anthropology 30. Smithsonian Institution Press, Washington D.C.

Story, Dee Ann

1981 An Overview of the Archaeology of East Texas. Plains Anthropologist 26(92):139-156. 1990 Cultural History. In The Archeology and Bioarcheology of the Coastal Plain: Volume I Arkansas Archeological Survey Research series 38.

1990 Environmental Setting. In The Archeology and Bioarcheology of the Gulf Coastal Plain, 2 vols., by D. A. Story, J. A. Guy, B. A. Burnett, M. D. Freeman, J. C. Rose,

D. G. Steele, B. W. Olive, and K. J. Reinhard, pp. 1:5-1:26. Research Series No. 38. Arkansas Archeological Survey, Fayetteville.

Suhm, Dee Ann, Alex D. Krieger, and Edward B. Jelks

1962 An Introductory Handbook of Texas Archeology. In Bulletin of the Texas Archeological Society, Volume 25.

Society for Historical Archaeology

2018 Historical Glass Bottle Identification and Information Website. Electronic document, https://sha.org/bottle/index.htm, accessed December 2019.

Texas Historical Commission

2019 Texas Archeological Sites Atlas. Electronic document. https://atlas.thc.state.tx.us/Account/Login, accessed October 2019.

Texas Historical Commission

2006 A Steward's Illustrated Key to Historic Ceramics. Electronic document. https://www.txhas.org/PDF/THC\%20Reference/CERAMICSfinal2.pdf, accessed December 2019.

2019 Texas Archeological Sites Atlas. Electronic document. https://atlas.thc.state.tx.us/Account/Login, accessed October 2019.

Texas Water Development Board

1991 USGS Geologic Atlas of Texas, Sherman Sheet. Electronic document, https://www.twdb.texas.gov/groundwater/aquifer/GAT/, accessed March 17, 2017. 
Toulouse, J.H.

1969 Fruit Jars. New York: Thomas Nelson \& Sons.

Wise County Clerk

1886 General Warranty Deed. Deed 8. Wise County Deed Records, Wise County, City of Decatur.

1903 General Warranty Deed. Vol 70,pg. 201. Wise County Deed Records, Wise County, City of Decatur

1910 General Warranty Deed. Vol 70, pg. 357. Wise County Deed Records, Wise County, City of Decatur.

Wise County Heritage Museum

n.d. Family Archives. Fortenberry Family. Wise County, City of Decatur.

Wise County Historical Survey Committee

1982 Wise County History: A Link with the Past, Vol. 2. Eakin Publications, Austin.

Wise County Messenger

1954“Services Held For James Washburn.” Obituaries, pg. 4. Wise County, City of Decatur. 



\section{APPENDIX A: DESIGN PLANS AND APE}




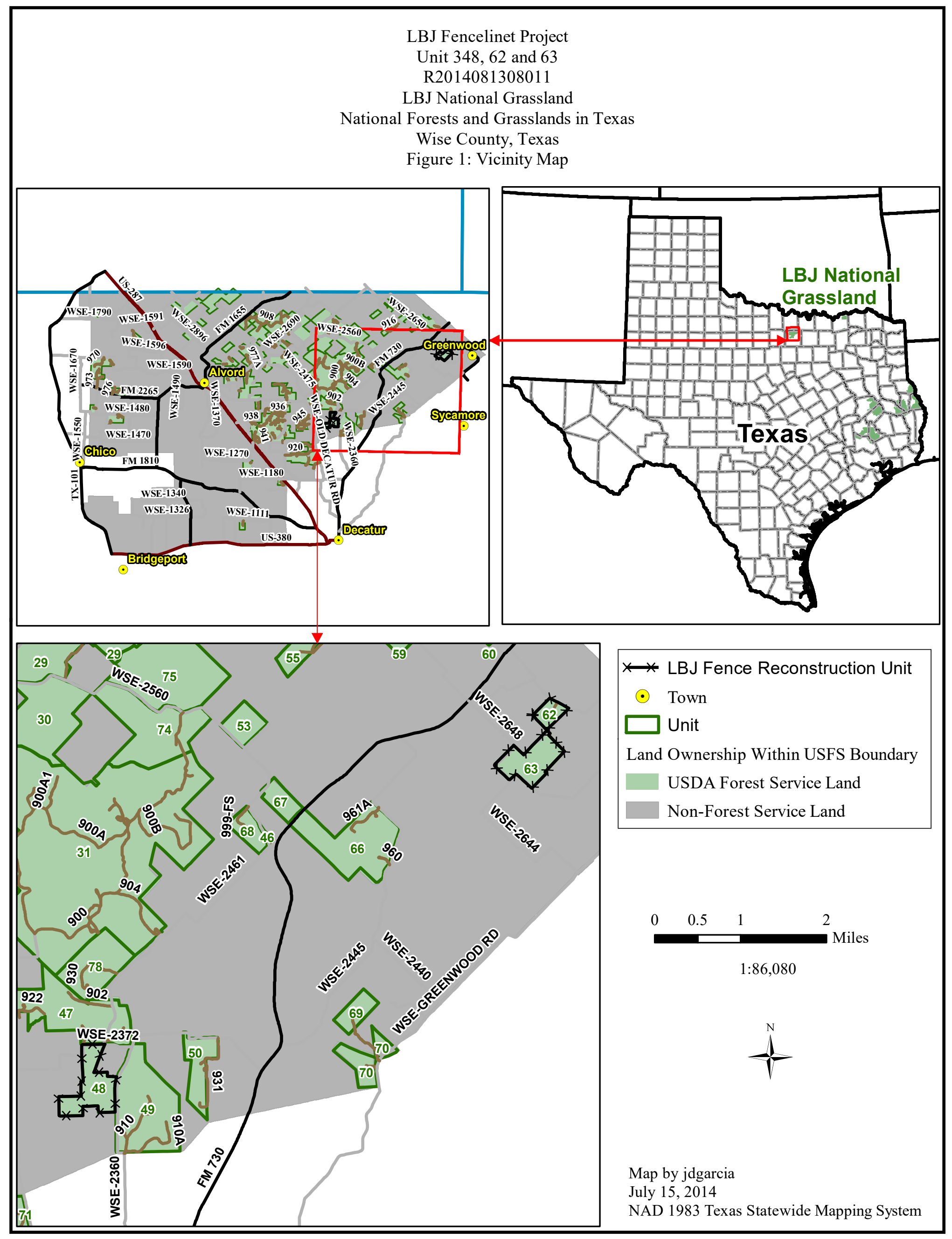




\section{LBJ Fenceline Project}

Unit 48

Lyndonj B. Johnson National Grasslands

National Forests \& Grasslands in Texas

Pecan Creek 7.5' Quadrangle

Wise County, Texas

Figure 2: Project Location Map

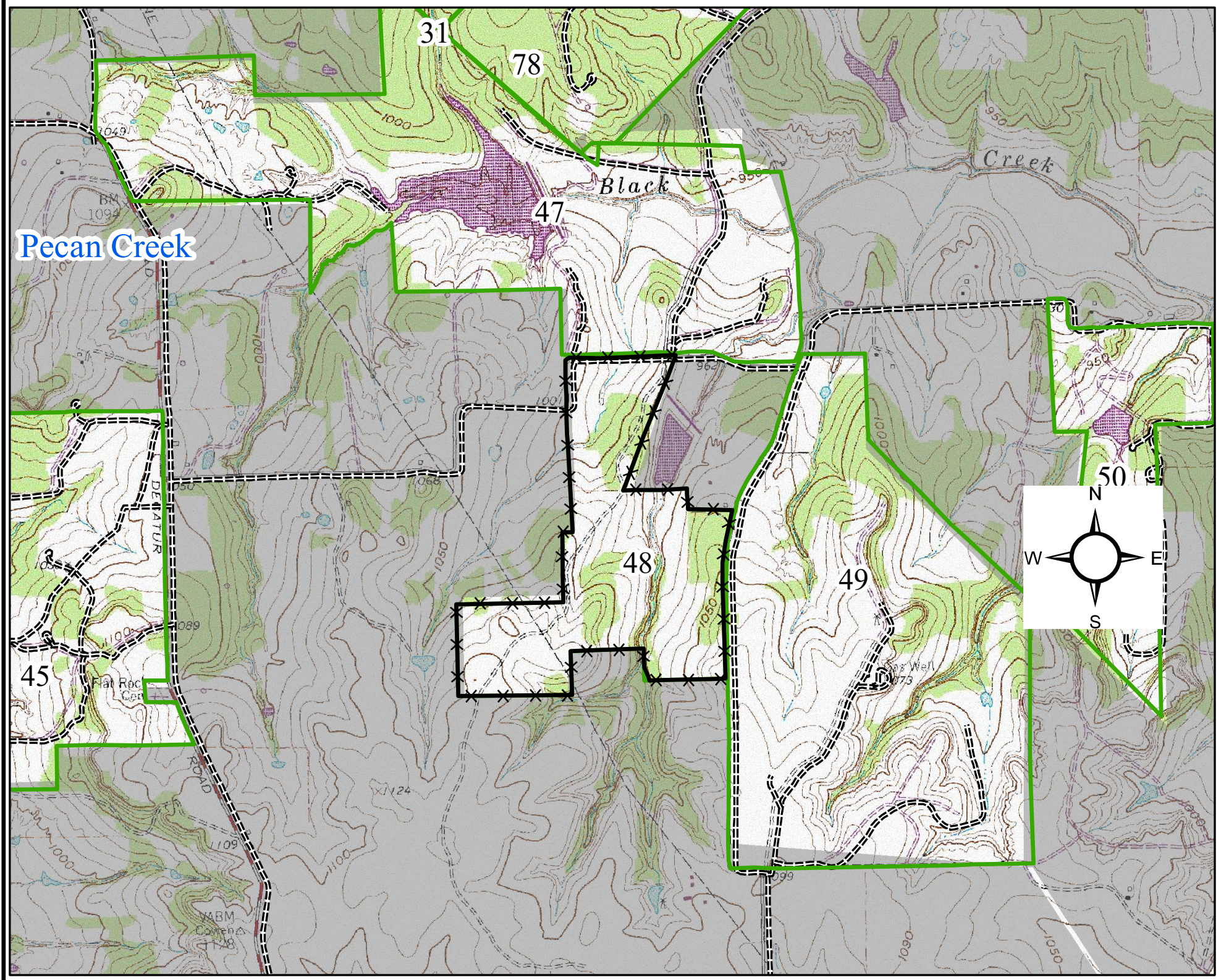

\section{$\longleftarrow$ L LBJ Fence Reconstruction Unit \\ $\square$ LBJ National Grassland \\ Non-Forest Service}

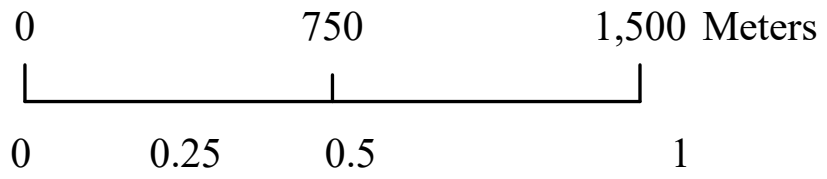

NAD 1983 Texas Statewide Mapping System 


\section{LBJ Fenceline Project}

Unit 62 and 63

Lyndonj B. Johnson National Grasslands

National Forests \& Grasslands in Texas

New Harp and Greenwood 7.5' Quadrangle

Wise County, Texas

Figure 3: Project Location Map

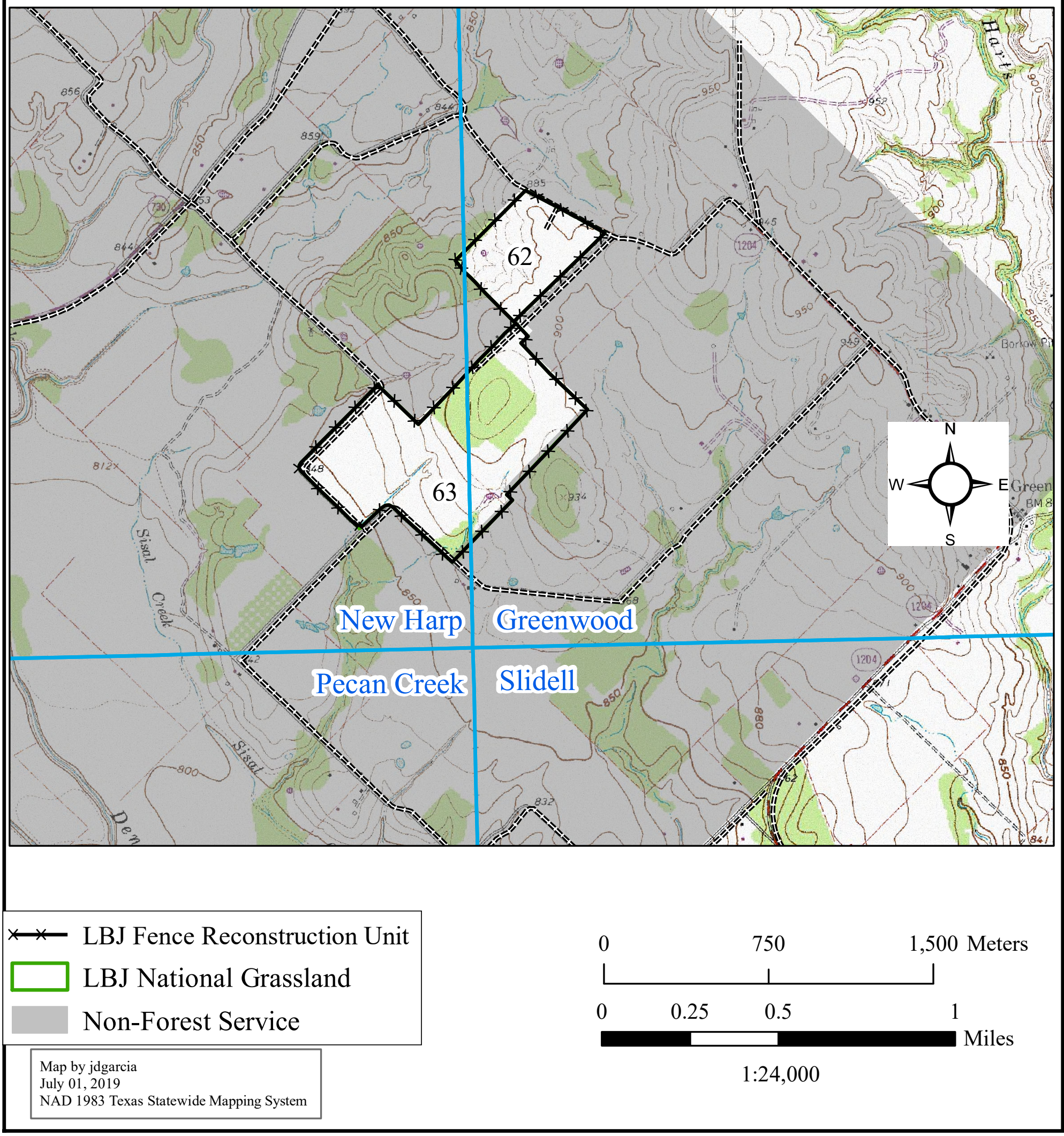


APPENDIX B: SHOVEL TEST RESULTS 


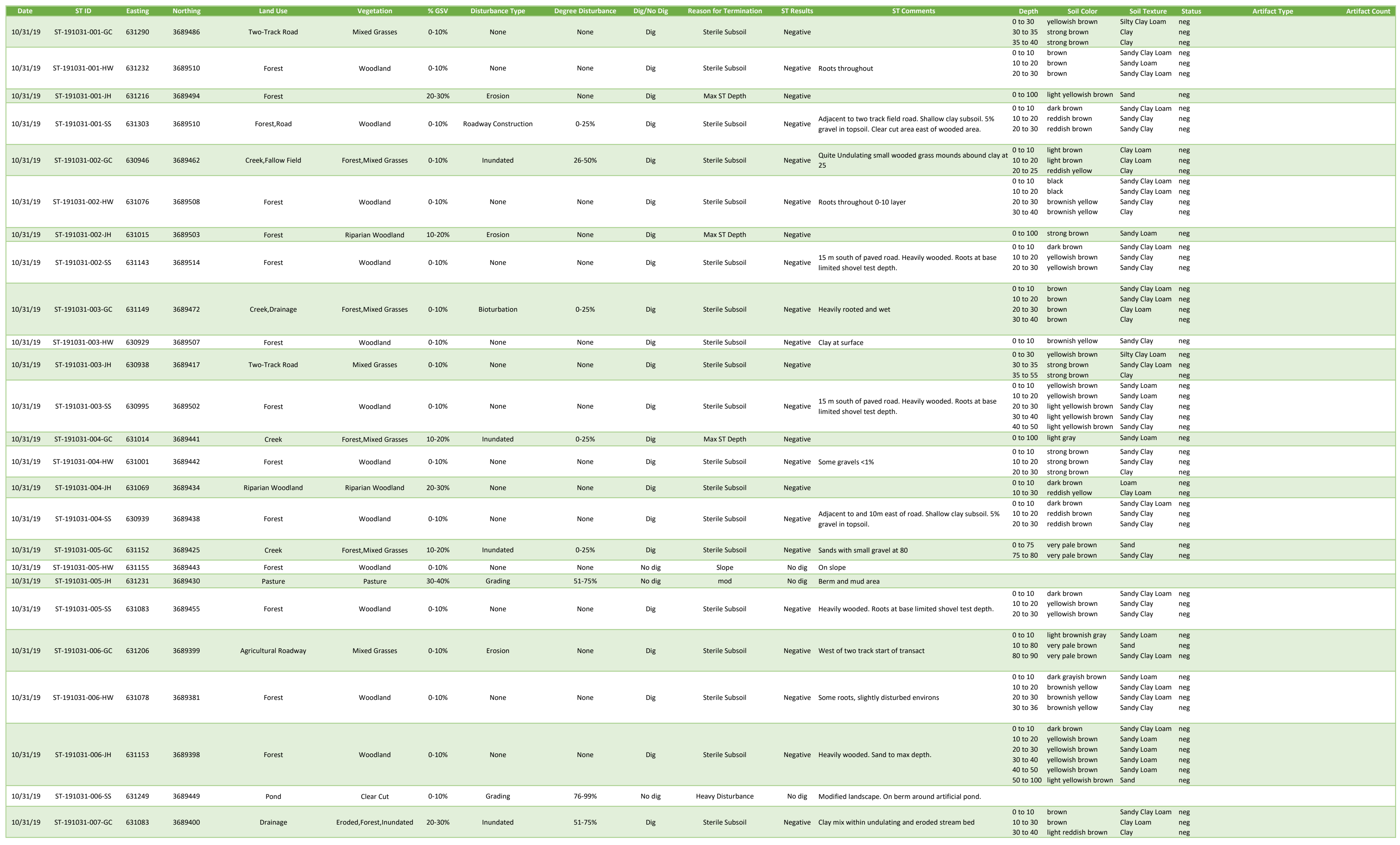




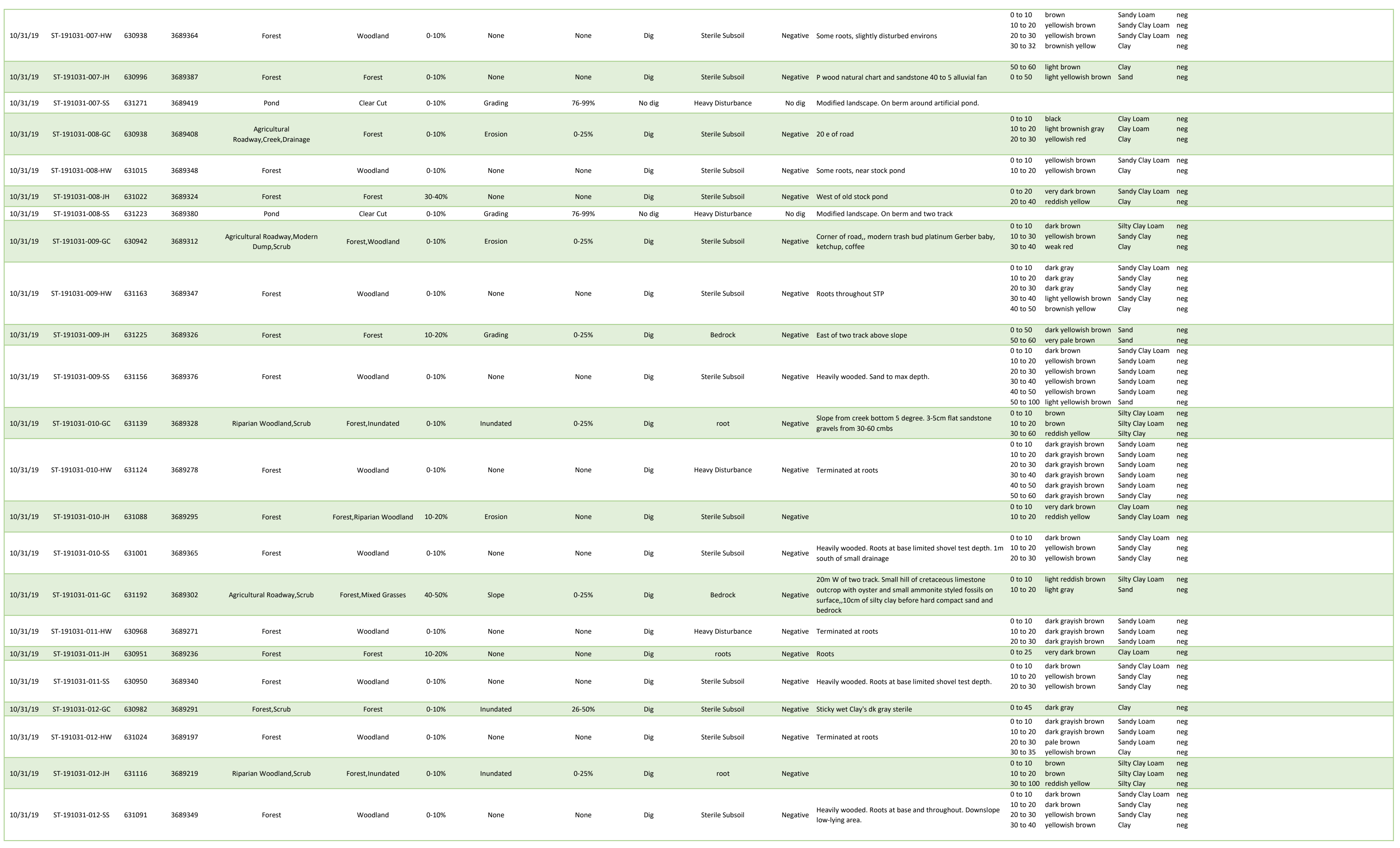




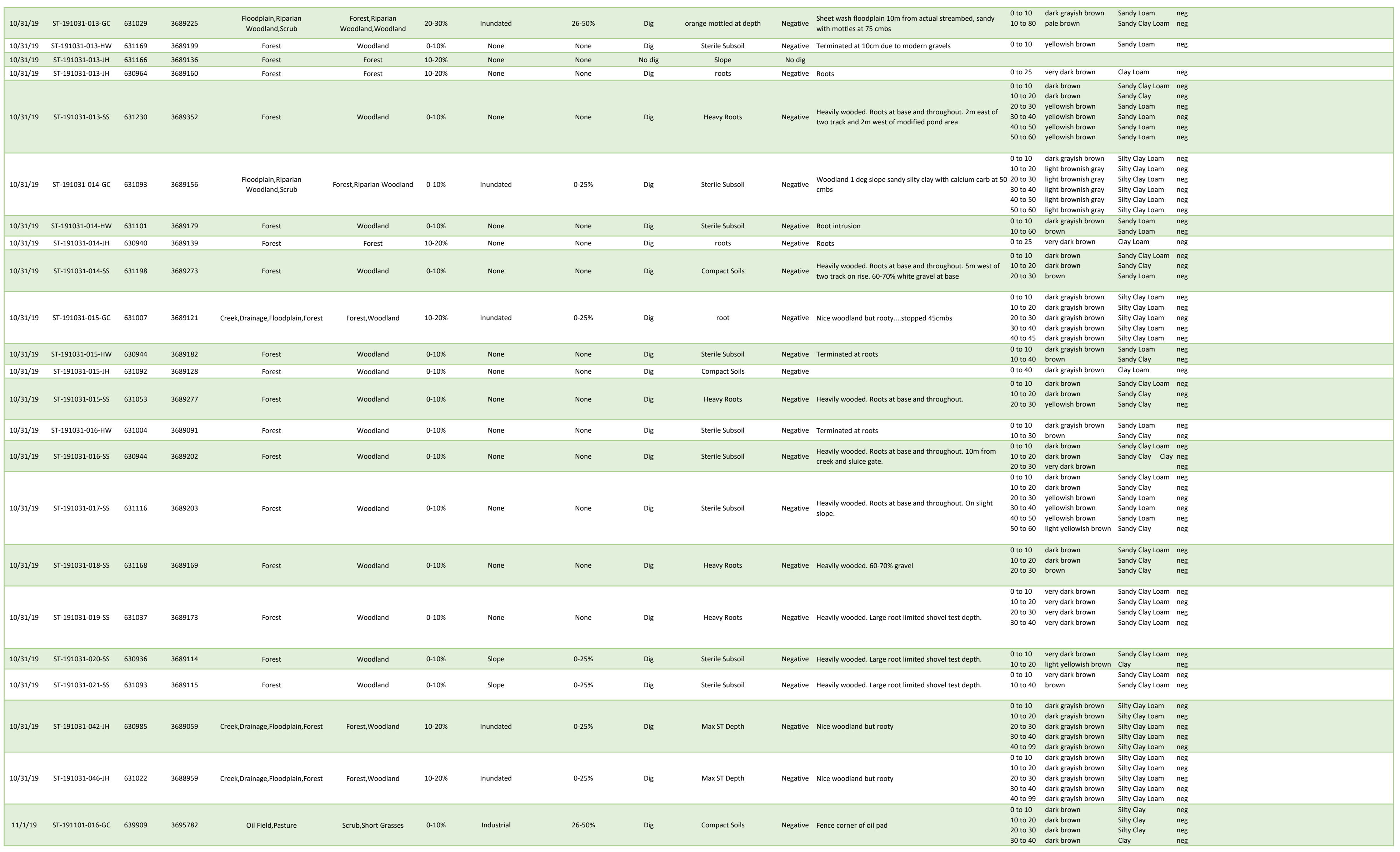




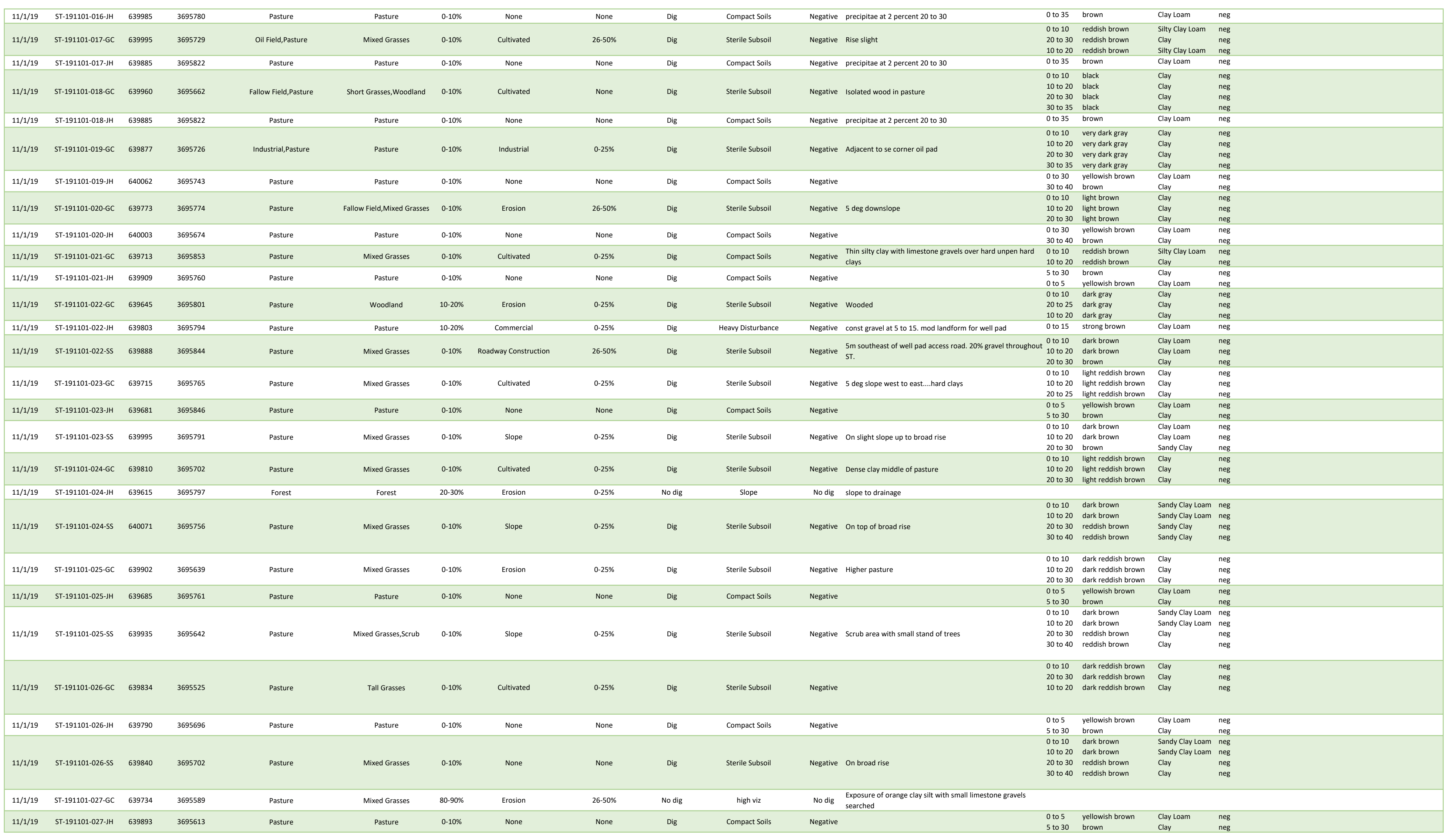




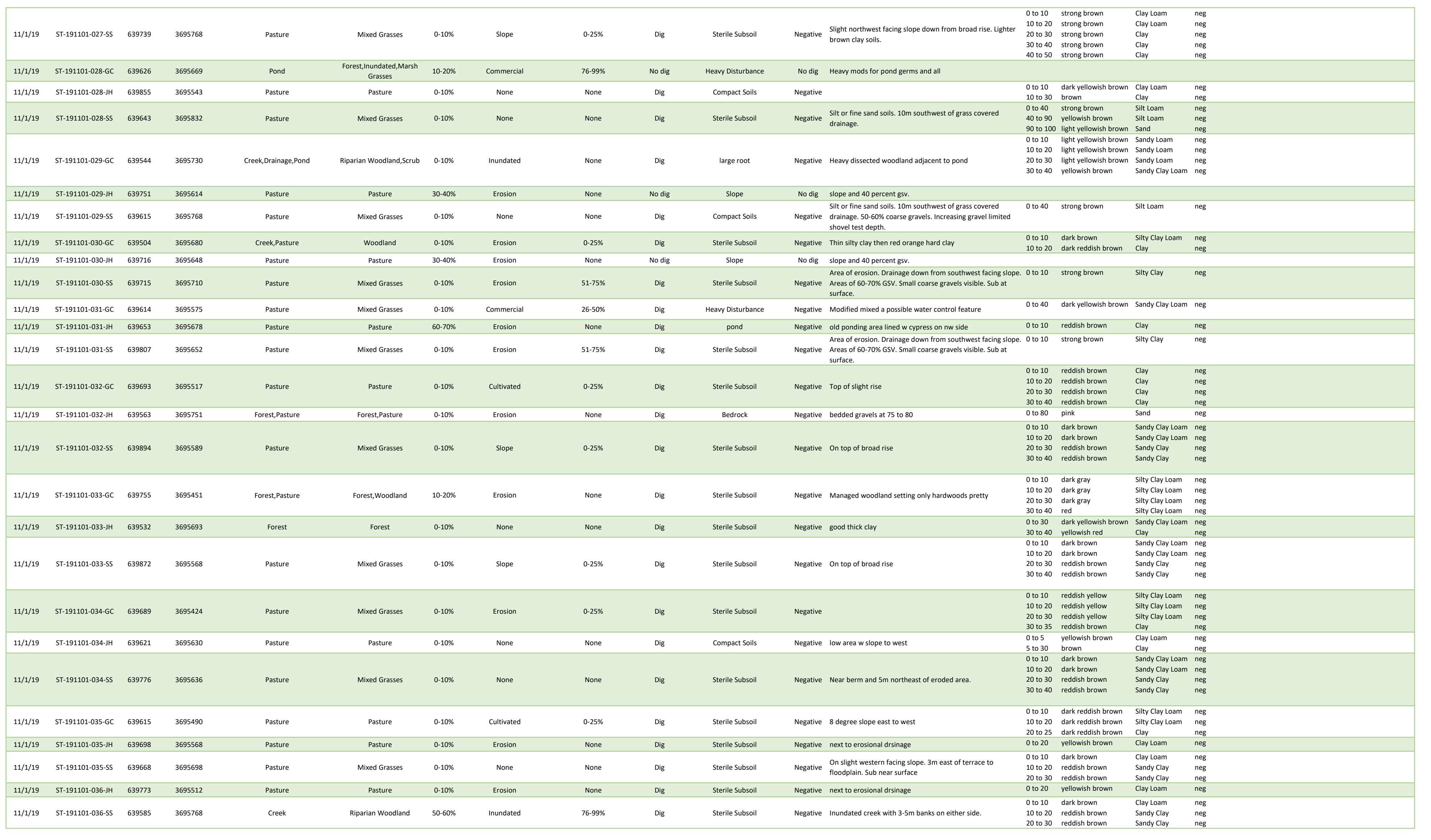




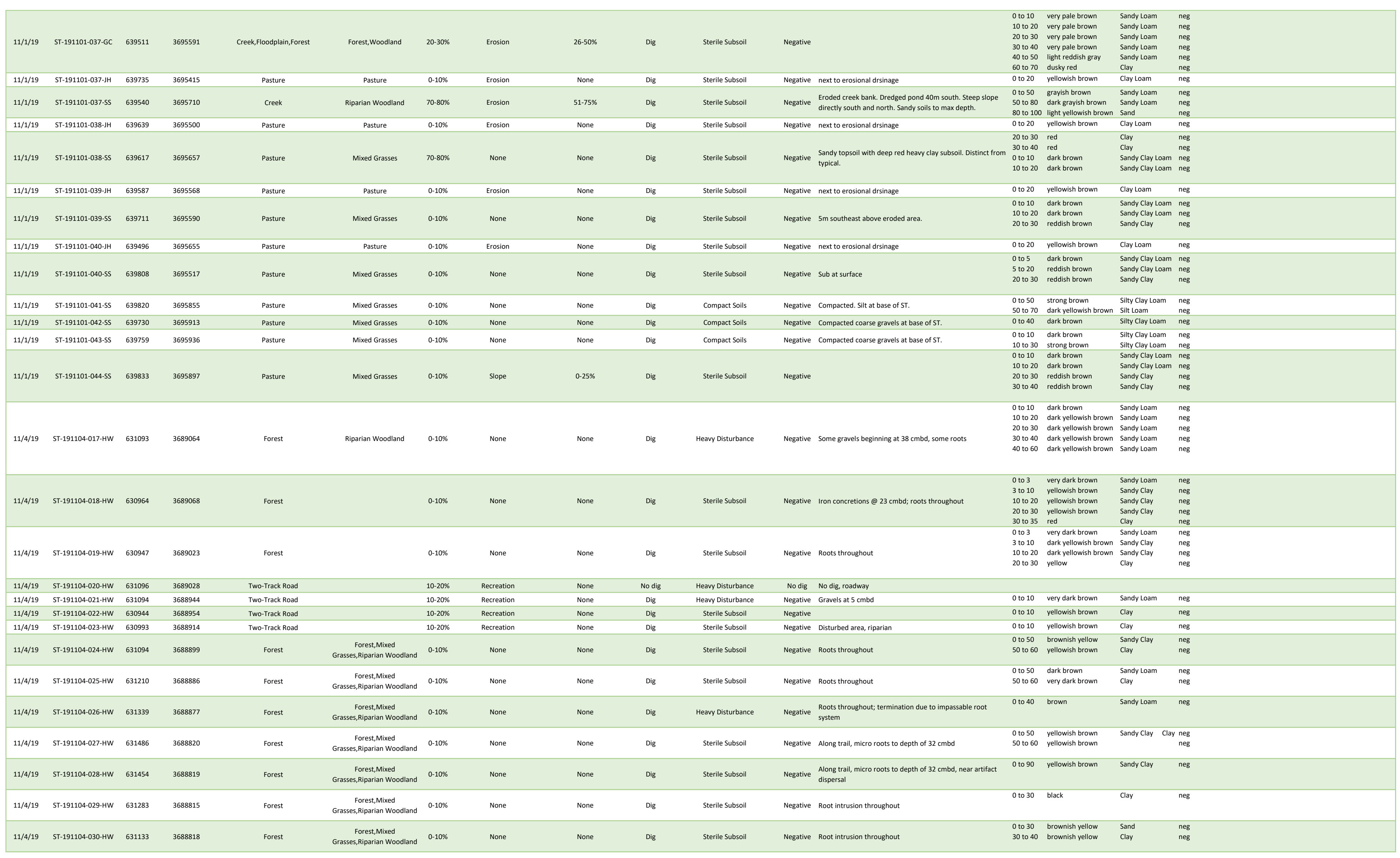




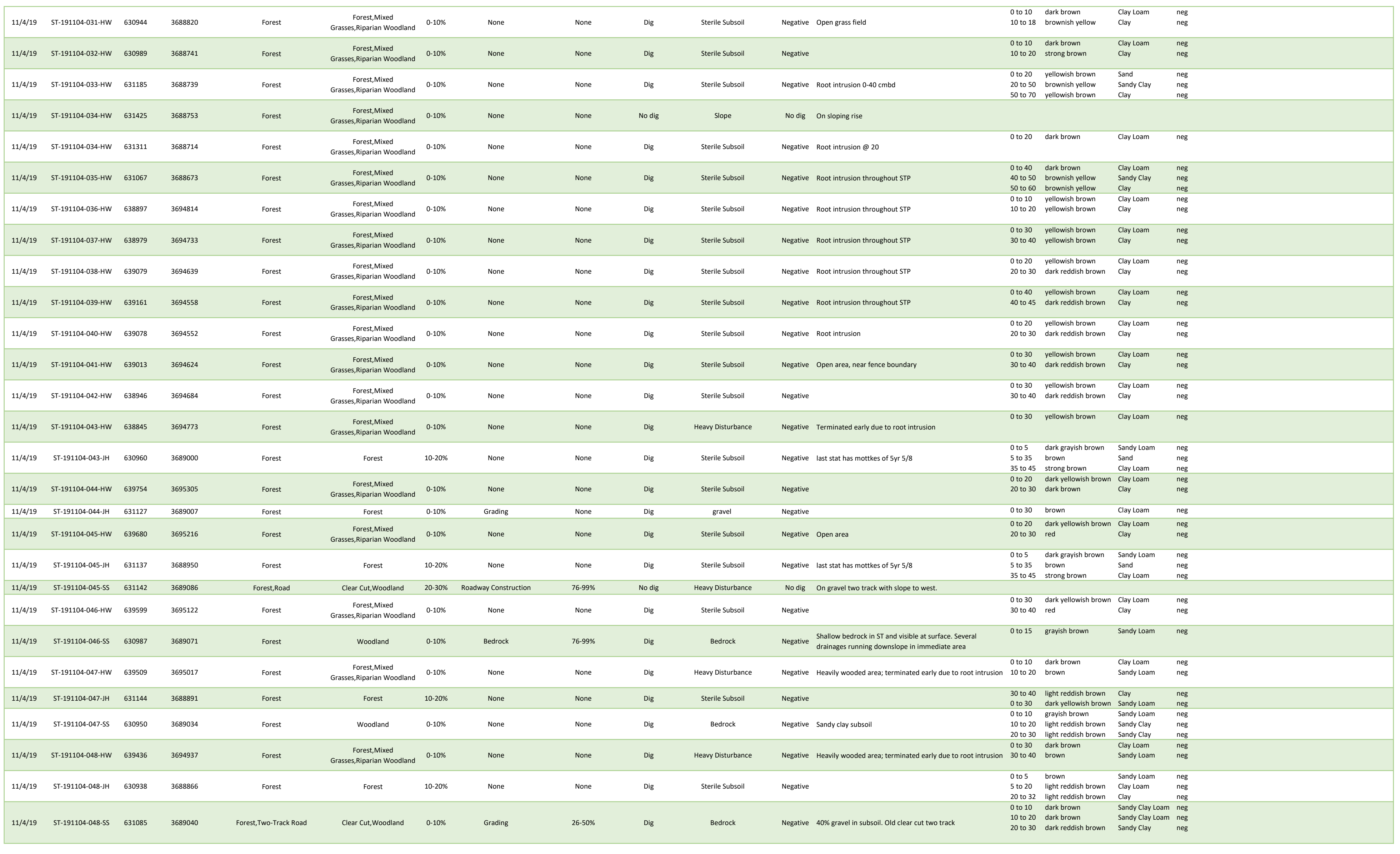




\begin{tabular}{|c|c|c|c|c|c|c|c|c|c|c|c|c|c|c|c|c|c|}
\hline 11/4/19 & ST-19100-049-HW & 639417 & 3694856 & Forest & $\begin{array}{c}\text { Forest,Mixed } \\
\text { Grasses,Riparian Woodland }\end{array}$ & $0.10 \%$ & None & None & Dig & Heary Disturbance & Negative & Heavily wooded area; terminated aarly due to root intrusion & $\begin{array}{l}\begin{array}{l}0 \text { to5 } \\
5 \text { to } 15 \\
15 \text { to } 25\end{array}\end{array}$ & $\begin{array}{l}\text { very dark gray } \\
\text { brown } \\
\text { yellowish brown }\end{array}$ & $\begin{array}{l}\text { Sandy Loam } \\
\text { Sandy Clay } \\
\text { Clay }\end{array}$ & $\begin{array}{l}\text { neg } \\
\text { neg } \\
\text { neg }\end{array}$ & \\
\hline 11/4/19 & ST-191104-049-JH & 631254 & 368880 & Forest & Forest & $0-10 \%$ & Erosion & None & No dig & Slope & Nodig & finger ridge to prom drainage. & & & & & \\
\hline $11 / 4 / 19$ & ST-191104-049-SS & 631142 & 3689038 & Forest,Two-Track Road & Clear Cut,Woodland & $20-30 \%$ & Grading & $76-99 \%$ & No dig & Heavy Disturbance & Nodig & On gravel two track with slope to west. & & & & & \\
\hline 11/4/19 & ST-191104-050-HW & 639855 & 369439 & Forest & $\begin{array}{l}\text { Forest,Mixed } \\
\text { Grasses, }, \text { iparian Woodland }\end{array}$ & $0-10 \%$ & None & None & Dig & Sterile Subsoil & Negative & Heavily wooded area & $\begin{array}{l}\begin{array}{l}0 \text { to } 10 \\
10 \text { to } 30\end{array}\end{array}$ & $\begin{array}{l}\text { dard yellowish brown } \\
\text { red }\end{array}$ & $\begin{array}{l}\text { Sandy Loam } \\
\text { Clay }\end{array}$ & $\begin{array}{l}\text { neg } \\
\text { neg }\end{array}$ & \\
\hline 11/4/19 & ST-191104-051-HW & $\begin{array}{l}639557 \\
63148\end{array}$ & $\begin{array}{l}3685854 \\
365028\end{array}$ & Forest & $\begin{array}{l}\text { Forest,Mixed } \\
\text { Grasses,Riparian Woodland }\end{array}$ & $0-10 \%$ & Grang & None & Dig ag & Sterile Subsoil & Noogag & 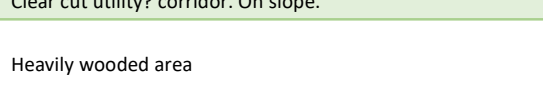 & $\begin{array}{l}\frac{0}{005} \\
5 \text { to } 15\end{array}$ & $\begin{array}{l}\text { dark yellowish brown } \\
\text { red }\end{array}$ & $\begin{array}{l}\text { Sandy Loam } \\
\text { Clay }\end{array}$ & $\begin{array}{l}\text { neg } \\
\text { neg }\end{array}$ & \\
\hline 11/4/19 & ST-191104-051-JH & 631541 & 368802 & Forest & Forest & $0-10 \%$ & None & None & Dig & Max ST Depth & Negative & root at $80 \mathrm{cmbs}$ & 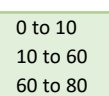 & $\begin{array}{l}\text { dark grayish brown } \\
\text { brown } \\
\text { brown }\end{array}$ & $\begin{array}{l}\text { Sandy Loam } \\
\text { Sand } \\
\text { Sandy Loam }\end{array}$ & $\begin{array}{l}\text { neg } \\
\text { neg } \\
\text { neg }\end{array}$ & \\
\hline 11/4/19 & ST-191104-051-SS & 631041 & 3688983 & Forest & Woodland & $0-10 \%$ & None & None & Dig & Bedrock & Negative & Along north-south drainage edge & 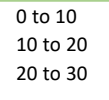 & 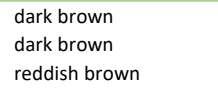 & $\begin{array}{l}\text { Sandy clay Lam } \\
\text { Sandy cyay loam } \\
\text { Sandy Clay }\end{array}$ & $\begin{array}{l}\text { neg } \\
\text { neg } \\
\text { neg }\end{array}$ & \\
\hline 11/4/19 & ST-191104-052-HW & 639630 & 3695087 & Forest & $\begin{array}{l}\text { Forest,Mixed } \\
\text { Grasses,Riparian Woodland }\end{array}$ & $0-10 \%$ & None & None & Dig & Sterile Subsoil & Negative & Heavily wooded area & $\begin{array}{l}\begin{array}{l}0 \text { to } 10 \\
10 \text { to } 20\end{array} \\
\end{array}$ & $\begin{array}{l}\text { dark vellowish brown } \\
\text { red }\end{array}$ & $\begin{array}{l}\text { Sandy Loam } \\
\text { Clay }\end{array}$ & $\begin{array}{l}\text { neg } \\
\text { neg }\end{array}$ & \\
\hline 11/4/19 & ST-191104-052-JH & 631475 & 3688799 & Energy Corridor & Forest & $10-20 \%$ & None & None & Dig & Max ST Depth & Positive & on site TS1 & 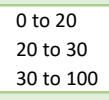 & $\begin{array}{l}\text { strong brown } \\
\text { reddish yellow } \\
\text { brown }\end{array}$ & $\begin{array}{l}\text { Sand } \\
\text { Sandy Clay Loam } \\
\text { Sand }\end{array}$ & $\begin{array}{l}\text { neg } \\
\text { pos } \\
\text { neg }\end{array}$ & age \\
\hline 11///19 & ST-191104-052-SS & 630948 & 3688981 & Forest & Woodland & $0-10 \%$ & None & None & Dig & Bedrock & Negative & Reddish sand. & 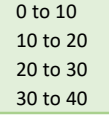 & $\begin{array}{l}\text { reddish brown } \\
\text { reddish brown } \\
\text { reddish brown } \\
\text { reddish brown }\end{array}$ & $\begin{array}{l}\text { Sandy Loam } \\
\text { Sandy Loam } \\
\text { Sandy Loam } \\
\text { Sandy clay }\end{array}$ & $\begin{array}{l}\text { neg } \\
\text { neg } \\
\text { neg } \\
\text { neg }\end{array}$ & \\
\hline 11//4/19 & ST-191104-053-HW & 639681 & 3695154 & Forest & $\begin{array}{l}\text { Forest, Mixed } \\
\text { Grasses,Riparian Woodland }\end{array}$ & $0-10 \%$ & None & None & Dig & Sterile Subsoil & Negative & Edge of forested area, in open & $\begin{array}{l}0 \text { to } 10 \\
10+020\end{array}$ & $\begin{array}{l}\begin{array}{l}\text { dark vellowish br } \\
\text { red }\end{array} \\
\text { ed }\end{array}$ & 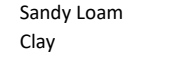 & $\begin{array}{c}\text { neg } \\
\text { neg }\end{array}$ & \\
\hline $11 / 4 / 19$ & ST-191104-053-JH & 631397 & 3688786 & Forest & Forest & $0-10 \%$ & Erosion & None & No dig & Slope & Nodig & & & & & & \\
\hline 11//4/19 & ST-191104-053-SS & 630945 & 3689922 & Forest & woodland & $0-10 \%$ & None & None & Dig & Bedrock & Negative & Red clay sub at surface & 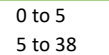 & $\begin{array}{l}\text { dark brown } \\
\text { reddish brown }\end{array}$ & $\begin{array}{l}\text { Sandy Clay Loam } \\
\text { Clay }\end{array}$ & $\begin{array}{c}\text { neg } \\
\text { neg }\end{array}$ & \\
\hline 11/4/19 & ST-191104-054-JH & 631331 & 3688819 & Forest & Forest & $10-20 \%$ & None & None & Dig & Sterile Subsoil & Negative & & 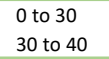 & $\begin{array}{l}\text { dark yellowish brown } \\
\text { light reddish brown }\end{array}$ & $\begin{array}{l}\text { Sandy Lam } \\
\text { Clay }\end{array}$ & $\begin{array}{l}\text { neg } \\
\text { neg }\end{array}$ & \\
\hline 11//4/19 & ST-191104-054-SS & 631092 & 3688928 & Forest & Woodland & $0-10 \%$ & None & None & Dig & Bedrock & Negative & Sugar sand & 0 to 100 & reddish brown & Sand & neg & \\
\hline 11///19 & ST-191104-055-HW & 639832 & 3695067 & Forest & $\begin{array}{l}\text { Forest, Mixed } \\
\text { Grasses, } R \text { riparian Woodand }\end{array}$ & $0-10 \%$ & None & None & Dig & Sterile Subsoil & Negative & & $\begin{array}{l}0 \text { to } 15 \\
15 \text { to } 30\end{array}$ & $\begin{array}{l}\text { dark vellowish brown } \\
\text { red }\end{array}$ & $\begin{array}{l}\text { Sandy Lam } \\
\text { Clay }\end{array}$ & $\begin{array}{l}\text { neg } \\
\text { neg }\end{array}$ & \\
\hline 11//4/19 & ST-191104-055-JH & 631174 & 3688796 & Forest & Forest & $10-20 \%$ & None & None & Dig & Sterile Subsoil & Negative & & 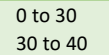 & $\begin{array}{l}\text { dark vellowish brown } \\
\text { light redish brown }\end{array}$ & $\begin{array}{l}\text { Sandy Loam } \\
\text { Clay }\end{array}$ & $\begin{array}{c}\text { neg } \\
\text { neg }\end{array}$ & \\
\hline 11/4/19 & ST-191104-055-SS & 631222 & 3688927 & Forest & Woodland & $0-10 \%$ & None & None & Dig & Bedrock & Negative & Open grassy rere in woods & 0 to 100 & reddish brown & Sand & neg & \\
\hline 11/4/19 & ST-191104-056-HW & 639751 & 3694974 & Forest & $\begin{array}{l}\text { Forest,Mixed } \\
\text { Grasses,Riparian Woodland }\end{array}$ & $0-10 \%$ & None & None & Dig & Sterile Subsoil & Negative & $x_{0}$ & $\begin{array}{l}\begin{array}{l}0 \\
0 \text { to } 30 \\
30 \text { to } 40\end{array} \\
\end{array}$ & $\begin{array}{l}\text { dark yellowish brown } \\
\text { red }\end{array}$ & $\begin{array}{l}\text { Sandy Loam } \\
\text { Clay }\end{array}$ & $\begin{array}{l}\text { neg } \\
\text { neg }\end{array}$ & \\
\hline 11//4/19 & ST-191104-056-SS & 631345 & 3688916 & Energy Corridor, Forest & Clear Cut,Woodland & $0-10 \%$ & Slope & $76-99 \%$ & No dig & slope & Nodig & On slope. & & & & & \\
\hline $11 / 4 / 19$ & ST-191104-057-HW & 639670 & 3694877 & Forest & $\begin{array}{l}\text { Forest,Mixed } \\
\text { Grasses,Riparian Woodland }\end{array}$ & $0-10 \%$ & None & None & Dig & Sterile Subsoil & Negative & & 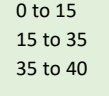 & $\begin{array}{l}\text { verry dara brown } \\
\text { light yellowish brown } \\
\text { yellowish brown }\end{array}$ & $\begin{array}{l}\text { Sandd Loam } \\
\text { Sandy Clay } \\
\text { Clay }\end{array}$ & $\begin{array}{l}\text { neg } \\
\text { neg } \\
\text { neg }\end{array}$ & \\
\hline 11///19 & ST-191104-057-JH & 630920 & 3688729 & Forest & Forest & $10-20 \%$ & None & None & Dig & Sterile Subsoil & Negative & 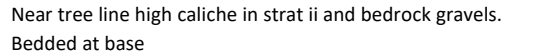 & $\begin{array}{l}0 \text { to } 20 \\
200400\end{array}$ & $\begin{array}{l}\text { dark brown } \\
\text { liaht brown }\end{array}$ & $\begin{array}{l}\text { Sandy Loam } \\
\text { Silty Clay Loam }\end{array}$ & $\begin{array}{l}\text { neg } \\
\text { neg }\end{array}$ & \\
\hline 11/4/19 & ST-191104-057-SS & 631550 & 368836 & Forest & woodland & $0-10 \%$ & None & None & Dig & Max ST Depth & Negative & Deep sand & 0 to 100 & yellowish brown & Sand & neg & \\
\hline 11//4/19 & ST-191104-058-HW & 639595 & 369475 & Forest & $\begin{array}{l}\text { Forest, Mixed } \\
\text { Grasses, Riparian Woodland }\end{array}$ & $0-10 \%$ & None & None & Dig & Sterile Subsoil & Negative & Clay a t surface & oto 10 & yellowish brown & Clay & neg & \\
\hline 11//4/19 & ST-191104-058-JH & 631130 & 3688738 & Forest & Forest & $10-20 \%$ & None & None & Dig & Sterile Subsoil & Negative & & $\begin{array}{l}0+2020 \\
20004\end{array}$ & $\begin{array}{l}\text { dark brown } \\
\text { light trown }\end{array}$ & $\begin{array}{l}\text { Sandy Laam } \\
\text { Silyclay Laom }\end{array}$ & $\begin{array}{c}\text { neg } \\
\text { neg }\end{array}$ & \\
\hline 11/4/19 & ST-191104-058-SS & 631442 & 3688228 & Forest & Woodland & $0-10 \%$ & None & None & Dig & Max ST Depth & Negative & Deep sand & 0 to 100 & yellowish brown & & neg & \\
\hline 11///19 & ST-19104-059-HW & 639668 & 3694699 & Forest & $\begin{array}{l}\text { Forest,Mixed } \\
\text { Grasses,Riparian Woodland }\end{array}$ & $0-10 \%$ & None & None & Dig & Sterile Subsoil & Negative & & $\begin{array}{l}\begin{array}{l}\text { ot } 15 \\
15+535 \\
35 \text { to } 40\end{array} \\
30\end{array}$ & $\begin{array}{l}\text { very dark brown } \\
\text { light tellowish brown } \\
\text { yellowish brown }\end{array}$ & $\begin{array}{l}\text { Sandy Lam } \\
\text { Sanyl clay } \\
\text { Clay }\end{array}$ & $\begin{array}{c}\text { neg } \\
\text { neg } \\
\text { neg }\end{array}$ & \\
\hline 11/4/19 & ST-191104-059-JH & 631278 & 3688740 & Forest & Forest & $0-10 \%$ & Erosion & None & No dig & slope & Nodig & Slope to draingege & & & & & \\
\hline 11/4/19 & ST-191104-059-SS & 631323 & 3688522 & Forest & Woodland & $0-10 \%$ & None & None & Dig & Max ST Depth & Negative & Black subsoil & $\begin{array}{l}\begin{array}{l}0 \\
1010 \\
10+020 \\
200030\end{array} \\
200\end{array}$ & $\begin{array}{l}\text { dark brown } \\
\text { dark brown } \\
\text { very dark brown }\end{array}$ & $\begin{array}{l}\text { Sandy Loam } \\
\text { Sandy Loam } \\
\text { Clay }\end{array}$ & $\begin{array}{l}\text { neg } \\
\text { neg } \\
\text { neg }\end{array}$ & \\
\hline
\end{tabular}




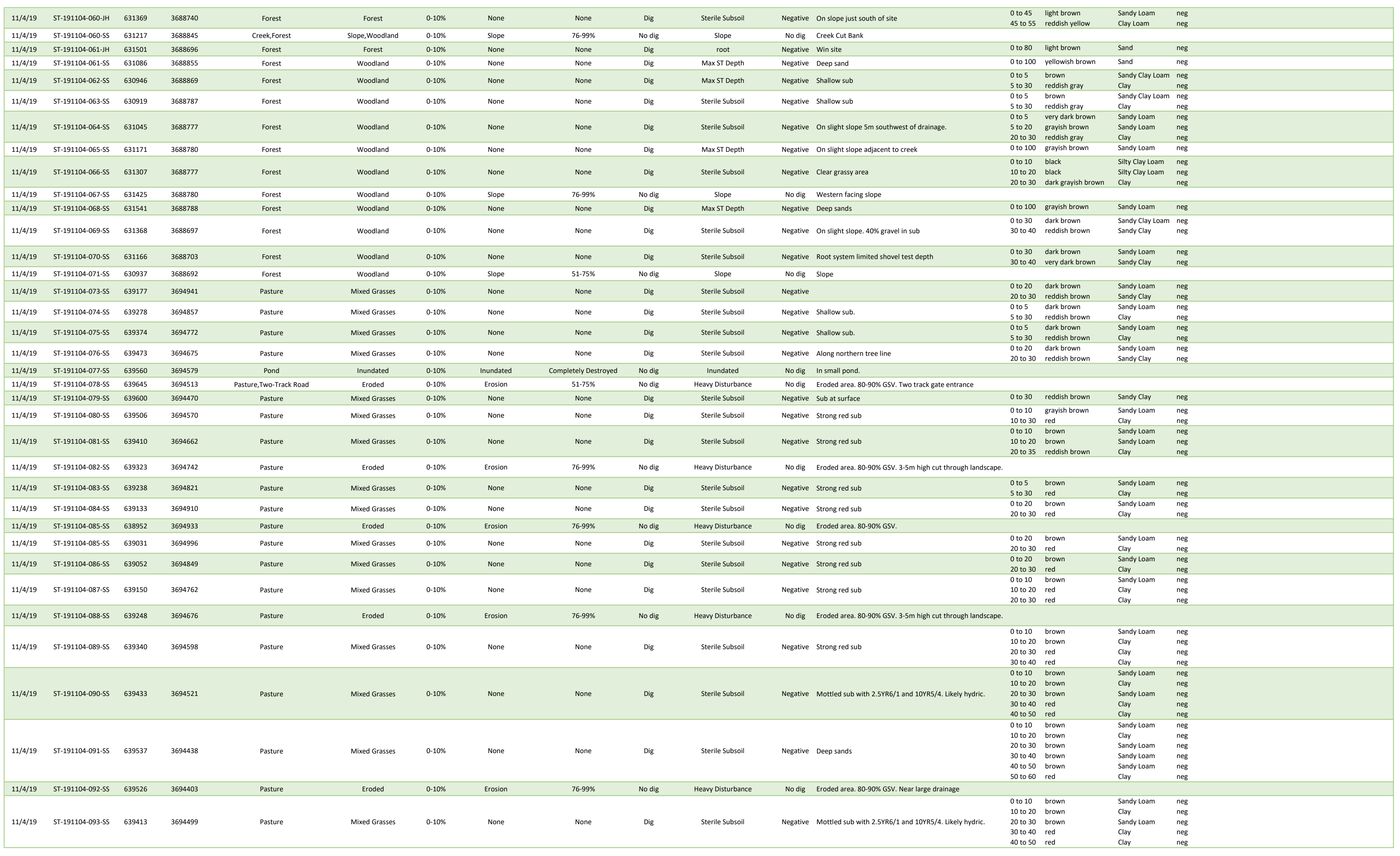




\begin{tabular}{|c|c|c|c|c|c|c|c|c|c|c|c|c|c|c|c|c|c|}
\hline 11///19 & ST-191104-094-SS & 639310 & 3694591 & Pasture & Mixed Grasses & $0.10 \%$ & None & None & Dig & Sterile Subsoil & Negative & Shallow strong red subsoil & 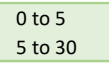 & $\begin{array}{l}\text { brown } \\
\text { red }\end{array}$ & $\begin{array}{l}\text { Sandy Loam } \\
\text { Clay }\end{array}$ & $\begin{array}{l}\text { neg } \\
\text { neg }\end{array}$ & \\
\hline $11 / 4 / 19$ & ST-191104-095-sS & 639208 & 3694680 & Pasture & Mixed Grasses & $0-10 \%$ & None & None & Dig & Sterile Subsoil & Negative & Shallow strong red subsoil & 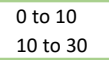 & $\begin{array}{l}\text { brown } \\
\text { red }\end{array}$ & $\begin{array}{l}\text { Sandy Lam } \\
\text { Clay }\end{array}$ & $\begin{array}{l}\text { neg } \\
\text { neg }\end{array}$ & \\
\hline 11//4/19 & ST-191104-096-SS & 639110 & 3694766 & Pasture & Mixed Grasses & $0-10 \%$ & None & None & Dig & Sterile Subsoil & Negative & Shallow strong red subsoil & 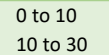 & $\begin{array}{l}\text { brown } \\
\text { red }\end{array}$ & $\begin{array}{l}\text { Sandy Loam } \\
\text { Clay }\end{array}$ & $\begin{array}{l}\text { neg } \\
\text { neg }\end{array}$ & \\
\hline 11//4/19 & ST-191104-097-SS & 638991 & 3694861 & Pasture & Mixed Grasses & $0-10 \%$ & None & None & Dig & Sterile Subsoil & Negative & Shallow strong red subsoil & 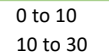 & $\begin{array}{l}\text { brown } \\
\text { red }\end{array}$ & $\begin{array}{l}\text { Sandy Loam } \\
\text { Clay }\end{array}$ & $\begin{array}{c}\text { neg } \\
\text { neg }\end{array}$ & \\
\hline 11/4/19 & ST-191104-098-SS & 638925 & 3694919 & Pasture & Pasture, Woodland & $0 .-10 \%$ & Roadway Construction & Completely Destroyed & No dig & Heavy Disturbance & Nodig & Road berm. & & & & & \\
\hline 11/5/19 & ST-191105-055-JH & 639054 & 3695039 & Pasture & Mixed Grasses & $0-10 \%$ & None & None & Dig & Sterile Subsoil & Negative & & 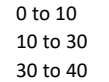 & $\begin{array}{l}\text { dark brown } \\
\text { strong brown } \\
\text { vellowish red }\end{array}$ & $\begin{array}{l}\text { Sandy Clay Loam } \\
\text { Clay Laam } \\
\text { Clay }\end{array}$ & $\begin{array}{l}\text { neg } \\
\text { neg } \\
\text { neg }\end{array}$ & \\
\hline 11/5/19 & ST-191105-057-JH & 639211 & 3694893 & Pasture & Mixed Grasses & $0-10 \%$ & None & None & Dig & Sterile Subsoil & Negative & & $\begin{array}{l}0 \text { to } 10 \\
10+030 \\
300040\end{array}$ & $\begin{array}{l}\text { dark brown } \\
\text { strong brown } \\
\text { yellowish red }\end{array}$ & $\begin{array}{l}\text { Sandy Clay Loam } \\
\text { Clay Loam } \\
\text { Clay }\end{array}$ & $\begin{array}{l}\text { neg } \\
\text { neg } \\
\text { neg } \\
\text { neg }\end{array}$ & \\
\hline 11/5/19 & ST-191105-058-JH & 639326 & 3694766 & Pasture & Mixed Grasses & $0.10 \%$ & None & None & Dig & Sterile Subsoil & Negative & & $\begin{array}{l}\begin{array}{l}0 \text { to } 10 \\
10+030 \\
30 \text { to } 40\end{array} \\
30\end{array}$ & $\begin{array}{l}\text { dark brown } \\
\text { strong brown } \\
\text { yellowish red }\end{array}$ & $\begin{array}{l}\text { Sandy Clay Loam } \\
\text { Clal Loam } \\
\text { Clay }\end{array}$ & $\begin{array}{l}\text { neg } \\
\text { neg } \\
\text { neg }\end{array}$ & \\
\hline $11 / 5 / 19$ & ST-191105-060-JH & 639539 & 3694562 & Pasture & Mixed Grasses & $0-10 \%$ & None & None & Dig & Sterile Subsoil & Negative & & 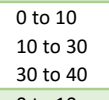 & $\begin{array}{l}\text { dark brown } \\
\text { strong brown } \\
\text { vellowish red }\end{array}$ & $\begin{array}{l}\text { Sandy Clay Loam } \\
\text { Cay Loam } \\
\text { Clay }\end{array}$ & $\begin{array}{l}\text { neg } \\
\text { neg } \\
\text { neg }\end{array}$ & \\
\hline 11/5/19 & ST-191105-061-JH & 639616 & 3694499 & Pasture & Mixed Grasses & $0-10 \%$ & None & None & Dig & Sterile Subsoil & Negative & & 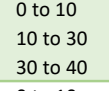 & $\begin{array}{l}\text { dark brown } \\
\text { strong brown } \\
\text { yellowish red }\end{array}$ & $\begin{array}{l}\text { Sandy Clay Loam } \\
\text { Clay Lam } \\
\text { Clay }\end{array}$ & $\begin{array}{l}\text { neg } \\
\text { neg } \\
\text { neg }\end{array}$ & \\
\hline $11 / 5 / 19$ & ST-191105-062-JH & 639580 & 3694457 & Pasture & Mixed Grasses & $0-10 \%$ & None & None & Dig & Sterile Subsoil & Negative & & 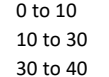 & $\begin{array}{l}\text { dark brown } \\
\text { strong brown } \\
\text { yellowish red }\end{array}$ & $\begin{array}{l}\text { Sandy Clay Loam } \\
\text { Clay Loam } \\
\text { Clay }\end{array}$ & $\begin{array}{l}\text { neg } \\
\text { neg } \\
\text { neg }\end{array}$ & \\
\hline 11/5/19 & ST-191105-063-JH & 639451 & 3694591 & Pasture & Mixed Grasses & $0-10 \%$ & None & None & Dig & Sterile Subsoil & Negative & & 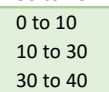 & $\begin{array}{l}\text { dark brown } \\
\text { strong brown } \\
\text { yellowish red }\end{array}$ & $\begin{array}{l}\text { Sandy Clay Loam } \\
\text { Clay Loam } \\
\text { Clay }\end{array}$ & $\begin{array}{l}\text { neg } \\
\text { neg } \\
\text { neg } \\
\text { neg }\end{array}$ & \\
\hline $11 / 5 / 19$ & ST-191105-064-JH & 639313 & 3694712 & Pasture & Mixed Grasses & $0-10 \%$ & None & None & Dig & Sterile Subsoil & Negative & near confluence of two small drainages & 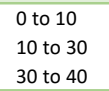 & $\begin{array}{l}\text { dark brown } \\
\text { strong brown } \\
\text { yellowish red }\end{array}$ & $\begin{array}{l}\text { Sandy Clay Loam } \\
\text { Clay Loam } \\
\text { Clay }\end{array}$ & $\begin{array}{l}\text { neg } \\
\text { negg } \\
\text { neg }\end{array}$ & \\
\hline $11 / 5 / 19$ & ST-191105-065-JH & 639192 & 3694834 & Pasture & Mixed Grasses & $0-10 \%$ & None & None & Dig & Sterile Subsoil & Negative & near confluence of two small drainages & $\begin{array}{l}\text { to } 10 \\
100030 \\
30 \text { to } 040\end{array}$ & $\begin{array}{l}\text { dark brown } \\
\text { strong brown } \\
\text { yellowish red }\end{array}$ & $\begin{array}{l}\text { Sandy Clay Loam } \\
\text { Clay Loam } \\
\text { Clay }\end{array}$ & $\begin{array}{l}\text { neg } \\
\text { neg } \\
\text { neg }\end{array}$ & \\
\hline $11 / 5 / 19$ & ST-191105-066-JH & 639066 & 3694940 & Pasture & Mixed Grasses & $0-10 \%$ & None & None & Dig & Sterile Subsoil & Negative & near confluence of two small drainages & 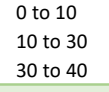 & $\begin{array}{l}\text { dark brown } \\
\text { strong brown } \\
\text { yellowish red }\end{array}$ & $\begin{array}{l}\text { Sandy Clay Loam } \\
\text { Clay Lam } \\
\text { Clay }\end{array}$ & $\begin{array}{l}\text { neg } \\
\text { neg } \\
\text { neg }\end{array}$ & \\
\hline 11/5/19 & ST-191105-067-JH & 639067 & 3699440 & Pasture & Mixed Grasses & $0-10 \%$ & None & None & Dig & Sterile Subsoil & Negative & & 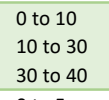 & $\begin{array}{l}\text { dark brown } \\
\text { strong brown } \\
\text { vellowish red }\end{array}$ & $\begin{array}{l}\text { Sandy Clay Lam } \\
\text { Cay Lam } \\
\text { Clay }\end{array}$ & $\begin{array}{l}\text { neg } \\
\text { neg } \\
\text { neg }\end{array}$ & \\
\hline 11/5/19 & ST-191105-068-JH & 638980 & 3694945 & Pasture & Mixed Grasses & $0-10 \%$ & None & None & Dig & Sterile Subsoil & Negative & & 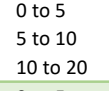 & $\begin{array}{l}\text { dark brown } \\
\text { strong brown } \\
\text { yellowish red }\end{array}$ & $\begin{array}{l}\text { Sandy Clay Loam } \\
\text { Clay Lam } \\
\text { Clay }\end{array}$ & $\begin{array}{l}\text { neg } \\
\text { neg } \\
\text { neg }\end{array}$ & \\
\hline 11/5/19 & ST-191105-069-JH & 639089 & 3694852 & Pasture & Mixed Grasses & $0-10 \%$ & None & None & Dig & Sterile Subsoil & Negative & & $\begin{array}{l}0 \text { to } 5 \\
5 \text { to } 10 \\
100202\end{array}$ & $\begin{array}{l}\text { darart brown } \\
\text { strong brown } \\
\text { yellowishred }\end{array}$ & $\begin{array}{l}\text { Sandy Clay Loam } \\
\text { Clay Lamm } \\
\text { Clay }\end{array}$ & $\begin{array}{l}\text { neg } \\
\text { neg } \\
\text { neg }\end{array}$ & \\
\hline $11 / 5 / 19$ & ST-191105-070-JH & 639196 & 3694777 & Pasture & Mixed Grasses & $0-10 \%$ & None & None & Dig & Sterile Subsoil & Negative & & $\begin{array}{l}\begin{array}{l}0 \text { to } 10 \\
10+030 \\
30 \text { to } 40\end{array} \\
\end{array}$ & $\begin{array}{l}\text { dark brown } \\
\text { strong brown } \\
\text { yellowish red }\end{array}$ & $\begin{array}{l}\text { Sandy Clay Loam } \\
\text { Clay Loam } \\
\text { Clay }\end{array}$ & $\begin{array}{l}\begin{array}{c}\text { neg } \\
\text { neg } \\
\text { neg }\end{array} \\
\text { neg }\end{array}$ & \\
\hline 11/5/19 & ST-191105-071-JH & 639319 & 3694533 & Pasture & Mixed Grasses & $0-10 \%$ & None & None & Dig & Sterile Subsoil & Negative & near confluence of two small drainages & $\begin{array}{l}\begin{array}{l}\text { to } 10 \\
10+030 \\
300040\end{array} \\
30 \text { to }\end{array}$ & $\begin{array}{l}\text { dark brown } \\
\text { strong rown } \\
\text { yellowish red }\end{array}$ & $\begin{array}{l}\text { Sandy Clay Loam } \\
\text { Clay Lam } \\
\text { Clay }\end{array}$ & $\begin{array}{l}\text { neg } \\
\text { neg } \\
\text { neg }\end{array}$ & \\
\hline $11 / 5 / 19$ & ST-191105-072-JH & 639444 & 3694511 & Pasture & Mixed Grasses & $0-10 \%$ & None & None & Dig & Sterile Subsoil & Negative & & 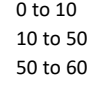 & $\begin{array}{l}\text { darkr brown } \\
\text { strong rown } \\
\text { yellowish red }\end{array}$ & $\begin{array}{l}\text { Sandy Clay Loam } \\
\text { Sandy Clay Loam } \\
\text { Clay }\end{array}$ & $\begin{array}{l}\text { neg } \\
\text { neg } \\
\text { neg }\end{array}$ & \\
\hline 11/5/19 & ST-191105-072-SS & 639067 & 3695042 & Pasture & Mixed Grasses & $0-10 \%$ & None & None & Dig & Sterile Subsoil & Positive & 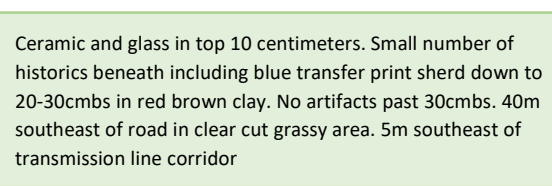 & 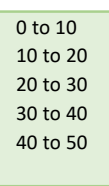 & $\begin{array}{l}\text { dark brown } \\
\text { reddish brown } \\
\text { light redish brown } \\
\text { light reddis brown } \\
\text { light redish brown }\end{array}$ & $\begin{array}{l}\text { Sandy Clay Loam } \\
\text { Sandy Clay Loam } \\
\text { Clay } \\
\text { Clay } \\
\text { Clay }\end{array}$ & 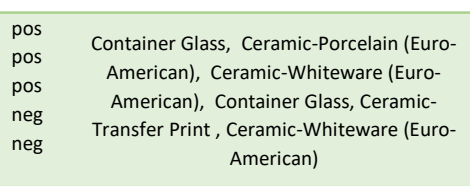 & 6 \\
\hline 11/5/19 & ST-191105-073-JH & 639552 & 369452 & Pasture & Mixed Grasses & $0-10 \%$ & None & None & Dig & thick root & Negative & & $\begin{array}{l}\begin{array}{l}\text { to } 10 \\
10 \text { to } 20\end{array} \\
\end{array}$ & $\begin{array}{l}\text { dark brown } \\
\text { strong brown }\end{array}$ & $\begin{array}{l}\text { Sandy Clay Lam } \\
\text { Clay Loam }\end{array}$ & $\begin{array}{l}\text { neg } \\
\text { neg }\end{array}$ & \\
\hline 11/5/19 & ST-191105-074-JH & 639510 & 3694376 & Pasture & Mixed Grasses & $0-10 \%$ & None & None & Dig & Sterile Subsoil & Negative & & 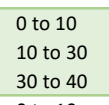 & $\begin{array}{l}\text { dark brown } \\
\text { strong brown } \\
\text { brown }\end{array}$ & $\begin{array}{l}\text { Sandy Clay Loam } \\
\text { Clay Loam } \\
\text { Clay }\end{array}$ & $\begin{array}{l}\text { neg } \\
\text { neg } \\
\text { neg }\end{array}$ & \\
\hline 11/5/19 & ST-191105-075-JH & 639390 & 3694483 & Pasture & Mixed Grasses & $0-10 \%$ & None & None & Dig & Sterile Subsoil & Negative & & 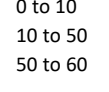 & $\begin{array}{l}\text { dark brown } \\
\text { strong brown } \\
\text { yellowish red }\end{array}$ & $\begin{array}{l}\text { Sandyd Clay Loam } \\
\text { Sandy Clay Loam } \\
\text { Clay }\end{array}$ & $\begin{array}{l}\text { neg } \\
\text { neg } \\
\text { neg }\end{array}$ & \\
\hline
\end{tabular}




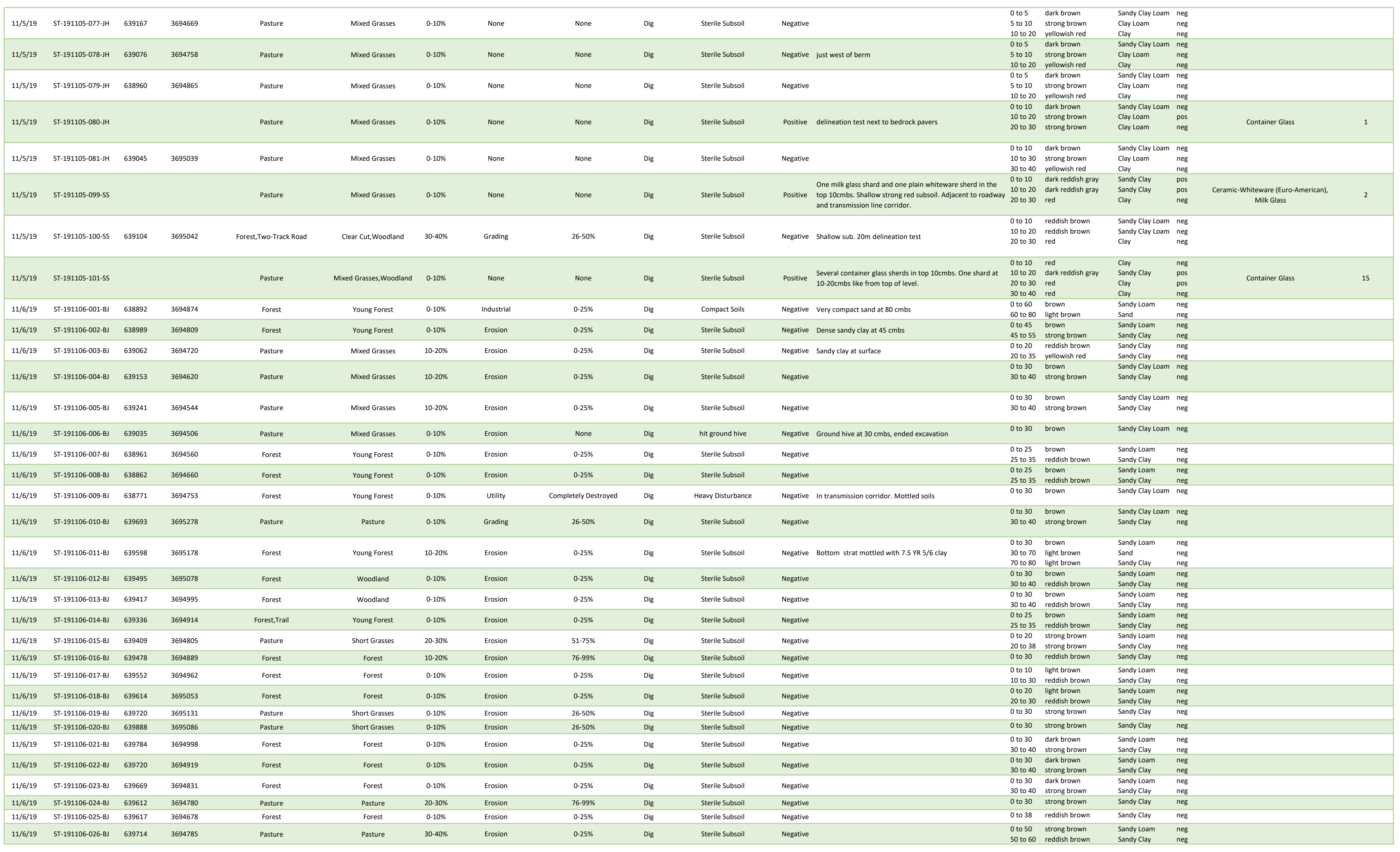




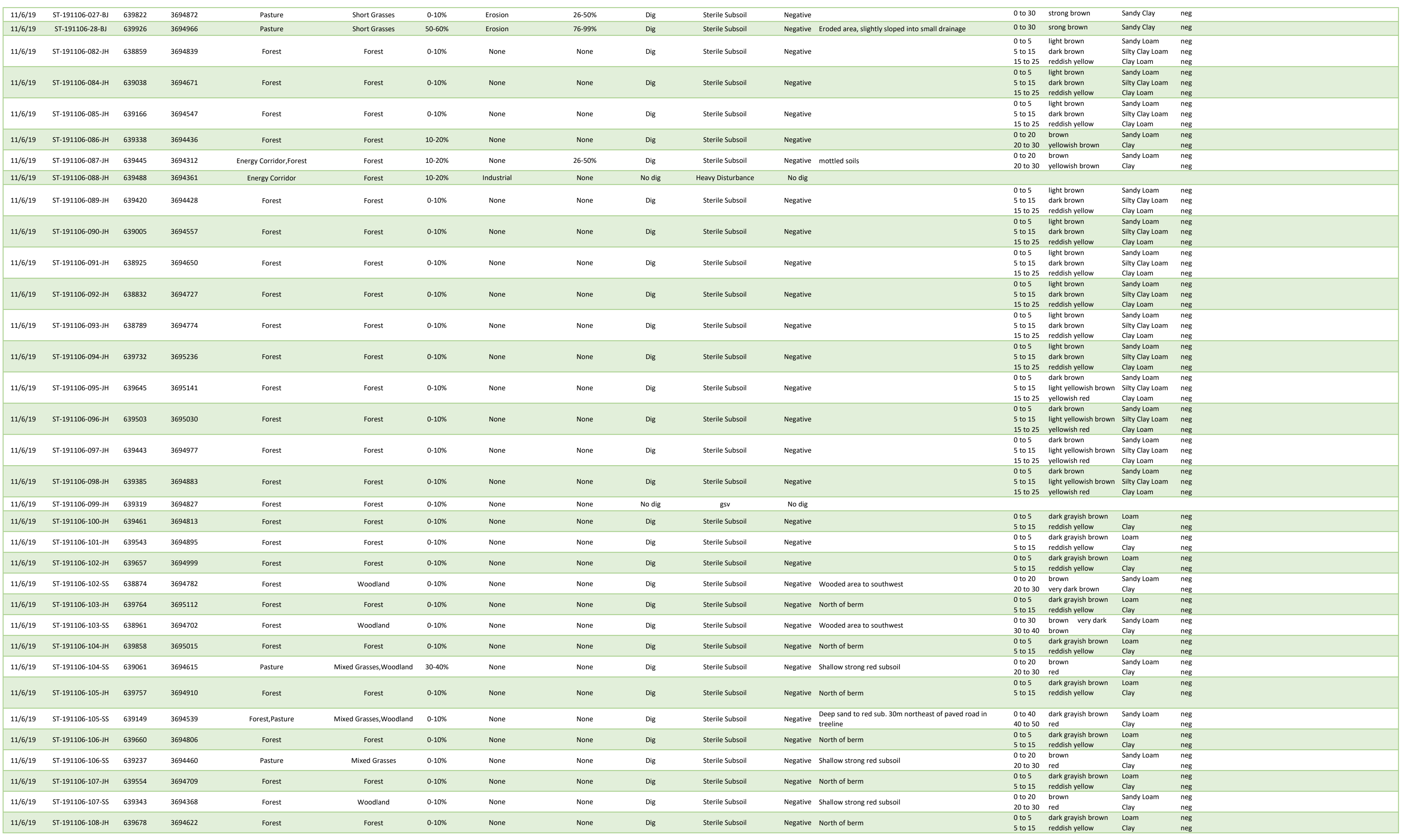




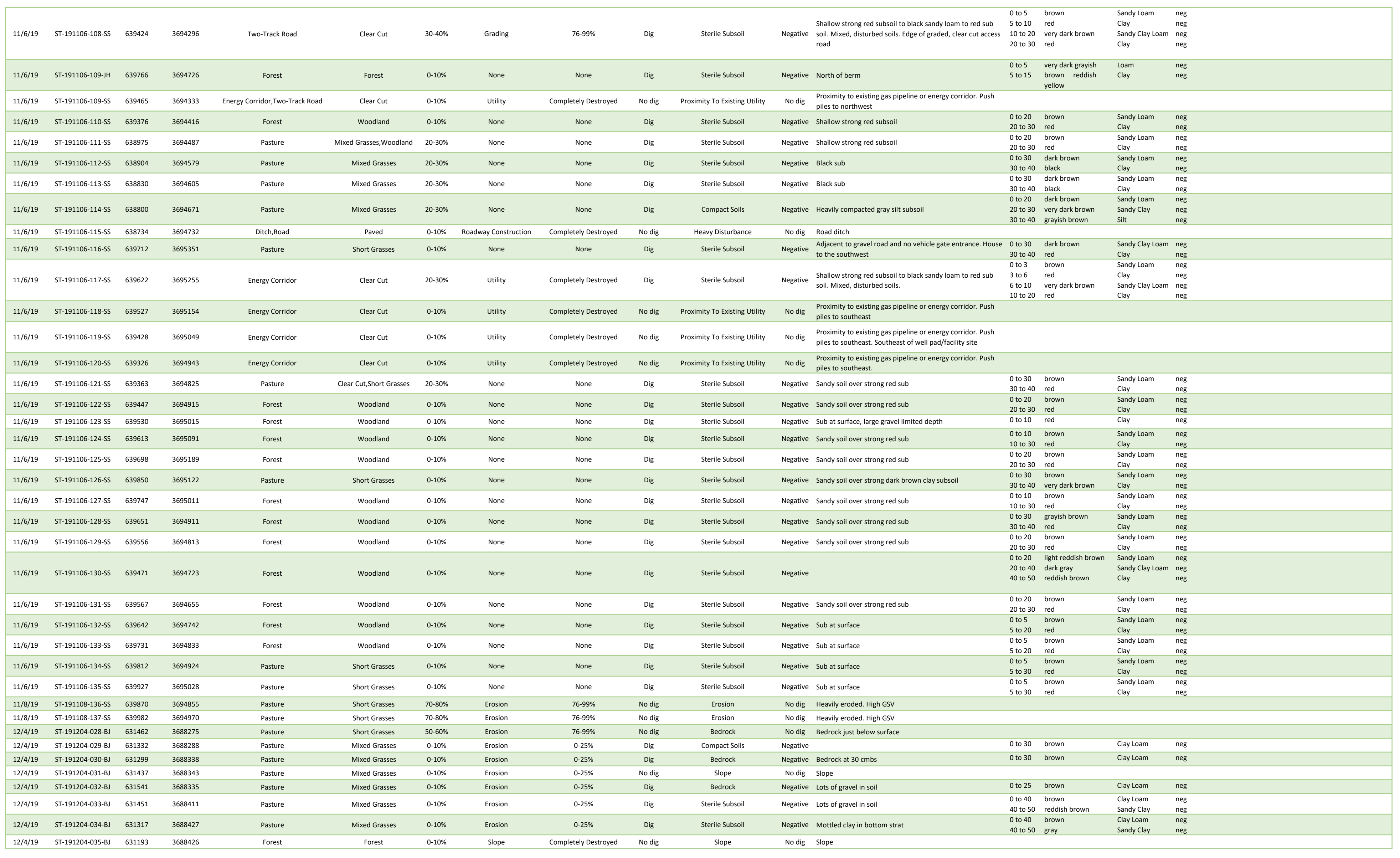




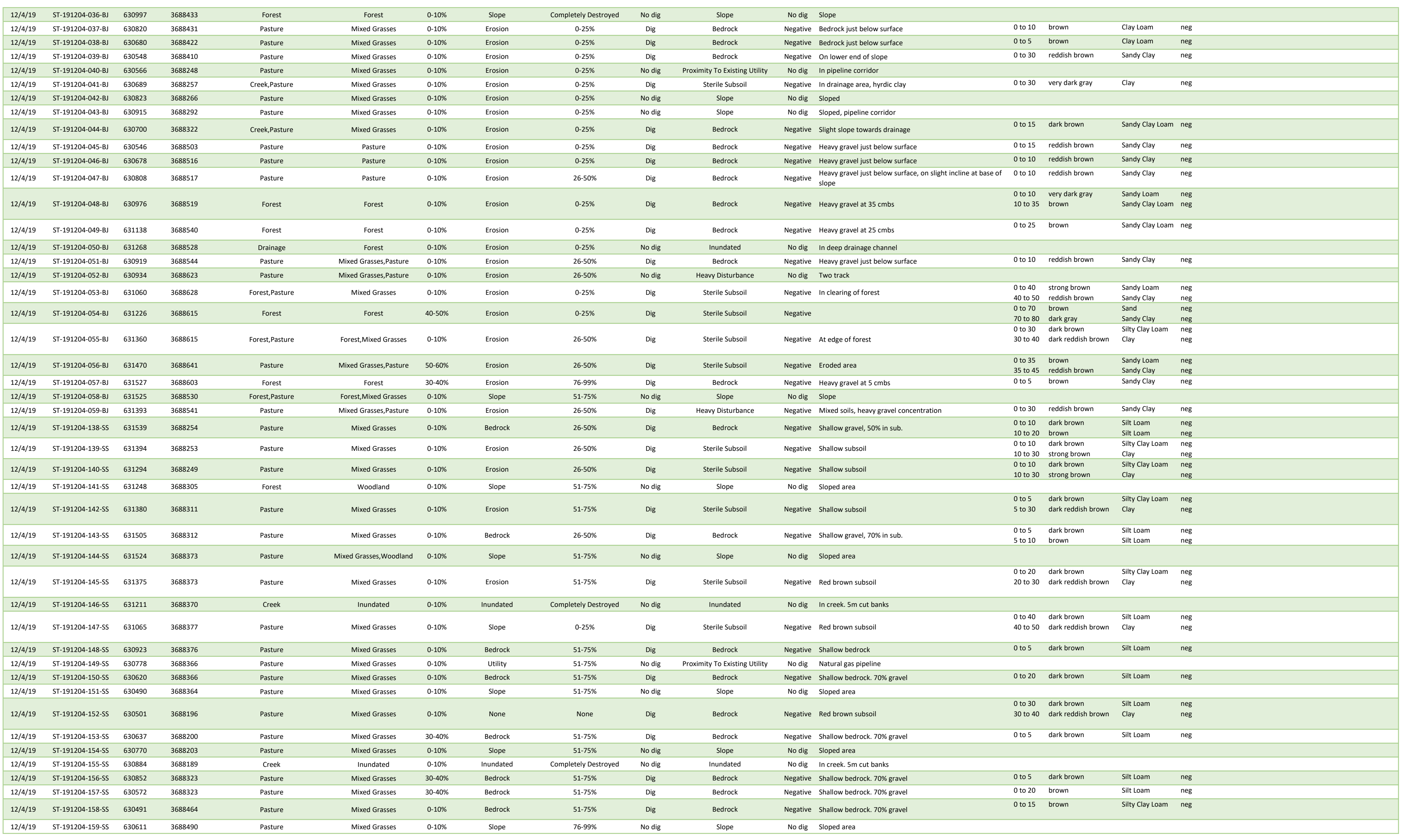




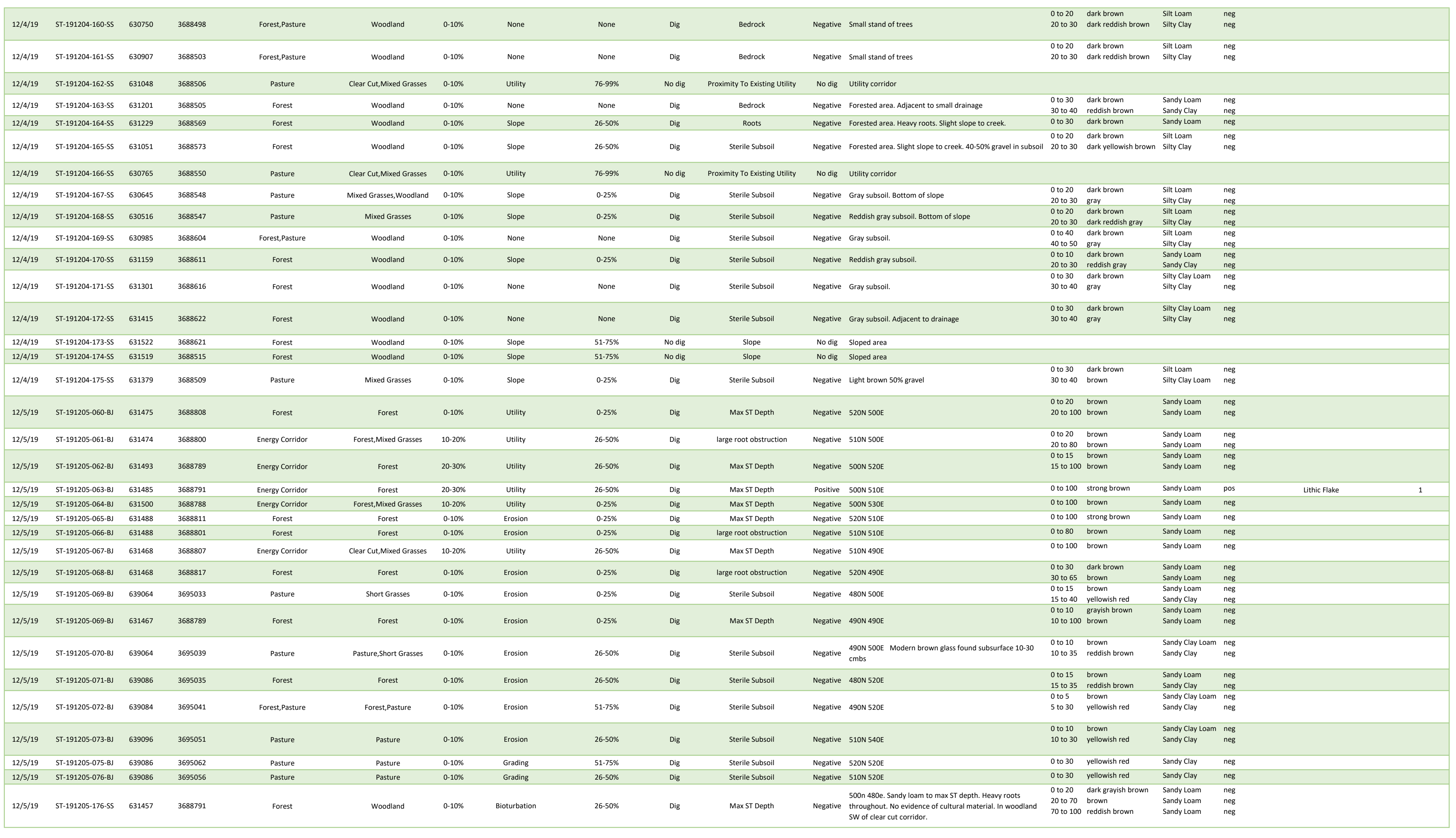




\begin{tabular}{|c|c|c|c|c|c|c|c|c|c|c|c|c|c|c|c|c|c|}
\hline 12/5/19 & ST-191205-177-SS & & & Energy Corridor, forest & Clear Cut,Woodland & $20-30 \%$ & Utility & $26-50 \%$ & Dig & Max ST Depth & Positive & 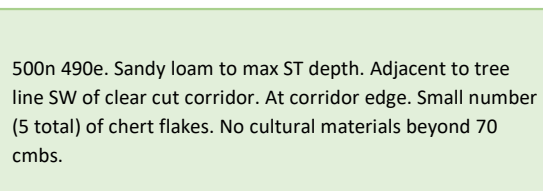 & 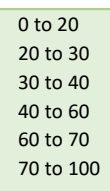 & $\begin{array}{l}\text { dark grayish brown } \\
\text { brown } \\
\text { brown } \\
\text { brown } \\
\text { brown } \\
\text { brown }\end{array}$ & $\begin{array}{l}\text { Sandy Loam } \\
\text { Sandy Loam } \\
\text { Sandy Loam } \\
\text { Sandy Loam } \\
\text { Sandy Loam } \\
\text { Sandy Loam }\end{array}$ & $\begin{array}{l}\text { neg } \\
\text { pos } \\
\text { pos } \\
\text { neg } \\
\text { pos } \\
\text { neg }\end{array}$ & 5 \\
\hline $12 / 5 / 19$ & ST-191205-178-SS & 631446 & 3688791 & Forest & Woodland & $0-10 \%$ & Bioturbation & $26-50 \%$ & Dig & Max ST Depth & Negative & 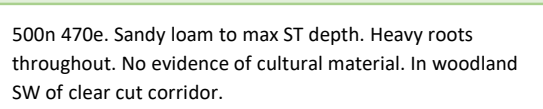 & 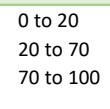 & $\begin{array}{l}\text { dark grayish brown } \\
\text { brown } \\
\text { reddish brown }\end{array}$ & $\begin{array}{l}\text { Sandy loam } \\
\text { sandy Loam } \\
\text { Sandy Laam }\end{array}$ & $\begin{array}{c}\substack{\text { neg } \\
\text { neg } \\
\text { neg }} \\
\text { neg }\end{array}$ & \\
\hline $12 / 5 / 19$ & ST-191205-179-SS & 631475 & 3688771 & Forest & Woodland & $0-10 \%$ & Bioturbation & $26-50 \%$ & Dig & Max ST Depth & Negative & 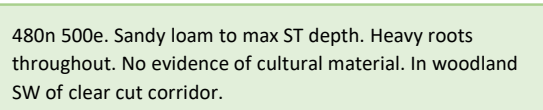 & 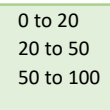 & $\begin{array}{l}\text { dark ravyish brown } \\
\text { brown } \\
\text { reddish brown }\end{array}$ & $\begin{array}{l}\text { Sandy loam } \\
\text { sanyl coam } \\
\text { sandy Loam } \\
\text { Lat }\end{array}$ & $\begin{array}{c}\text { neg } \\
\text { neg } \\
\text { neg }\end{array}$ & \\
\hline $12 / 5 / 19$ & ST-191205-180-SS & 631475 & 3688783 & Forest & Woodland & $0-10 \%$ & Bioturbation & $26-50 \%$ & Dig & Root & Negative & 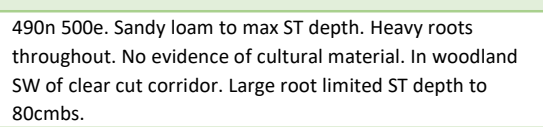 & $\begin{array}{l}\begin{array}{l}0 \\
2020 \\
20+060 \\
600080\end{array}\end{array}$ & $\begin{array}{l}\text { dark grazish brown } \\
\text { brown } \\
\text { reddish brown }\end{array}$ & $\begin{array}{l}\text { Sandy Loam } \\
\text { sandy Loam } \\
\text { Sandy Loam }\end{array}$ & $\begin{array}{c}\text { neg } \\
\text { neg } \\
\text { neg }\end{array}$ & \\
\hline $12 / 5 / 19$ & ST-191205-181-SS & 631486 & 3688772 & Forest & Woodland & $0-10 \%$ & Bioturbation & $0.25 \%$ & Dig & Max ST Depth & Negative & 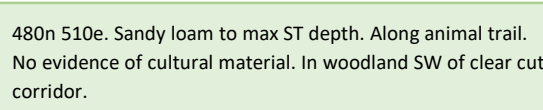 & $\begin{array}{l}0 \text { to } 10 \\
\text { to to to } \\
70 \text { to } 100\end{array}$ & $\begin{array}{l}\text { light vellowish brown } \\
\text { brewn } \\
\text { reddish brown }\end{array}$ & $\begin{array}{l}\text { Sandy loam } \\
\text { sanyl loam } \\
\text { Sandy loam }\end{array}$ & $\begin{array}{c}\text { neg } \\
\text { neg } \\
\text { neg }\end{array}$ & \\
\hline $12 / 5 / 19$ & ST-191205-182-SS & 631485 & 3688783 & Forest & Woodland & $0-10 \%$ & Bioturbation & $0-25 \%$ & Dig & Max ST Depth & Negative & 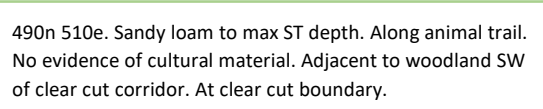 & 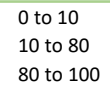 & $\begin{array}{l}\text { light vellowish brown } \\
\text { brewis } \\
\text { reddish hrown }\end{array}$ & $\begin{array}{l}\text { Sandy loam } \\
\text { Sandy loam } \\
\text { Sandy loam }\end{array}$ & $\begin{array}{c}\text { neg } \\
\text { neg } \\
\text { neg }\end{array}$ & \\
\hline 12/5/19 & ST-191205-183-SS & 631468 & 3688779 & Forest & Woodland & $0-10 \%$ & Bioturbation & $0.25 \%$ & Dig & Max ST Depth & Negative & 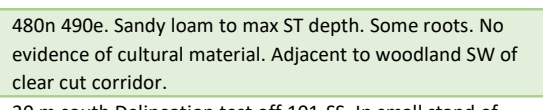 & $\begin{array}{l}\begin{array}{l}0 \\
\text { to } 20 \\
20 \text { to } 100\end{array} \\
\end{array}$ & $\begin{array}{l}\text { brown } \\
\text { brown }\end{array}$ & $\begin{array}{l}\text { Sandy Lam } \\
\text { Sandy Loam }\end{array}$ & $\begin{array}{l}\text { neg } \\
\text { neg }\end{array}$ & \\
\hline 12/5/19 & ST-191205-184-SS & 639095 & 3695026 & Forest & Woodland & $0 .-10 \%$ & Bioturbation & $0.25 \%$ & Dig & Sterile Subsoil & Negative & 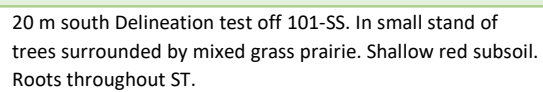 & 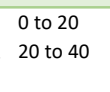 & $\begin{array}{l}\text { dark brown } \\
\text { red }\end{array}$ & $\begin{array}{l}\text { Silty Clay Loam } \\
\text { Clay }\end{array}$ & $\begin{array}{l}\begin{array}{l}\text { neg } \\
\text { neg }\end{array} \\
\text { no }\end{array}$ & \\
\hline $12 / 5 / 19$ & ST-191205-185-SS & 639094 & 3695038 & Forest & Woodland & $0-10 \%$ & Bioturbation & $0.25 \%$ & Dig & Sterile Subsoil & Negative & 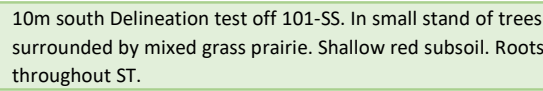 & $\begin{array}{l}5 \\
52020200 \\
52040\end{array}$ & $\begin{array}{l}\text { dark brown } \\
\text { red }\end{array}$ & $\begin{array}{l}\text { Silty Clay Loam } \\
\text { Clay }\end{array}$ & $\begin{array}{l}\text { neg } \\
\text { neg }\end{array}$ & \\
\hline 12/5/19 & ST-191205-186-5S & 639112 & 3695043 & Drainge, Forest & Inundated, Woodland & $0-10 \%$ & Grading & $76-99 \%$ & No dig & Heary Disturbance & No dig & 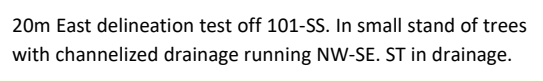 & & & & & \\
\hline 12/5/19 & ST-191205-187-SS & 639095 & 3695060 & Drainage, Forest & Inundated, Woodland & $0-10 \%$ & Grading & $76-99 \%$ & No dig & Heavy Disturbance & No dig & 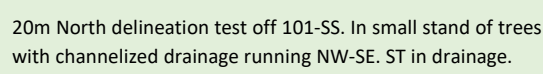 & & & & & \\
\hline 12/5/19 & ST-191205-188-SS & 639068 & 3695052 & Energy Corridor, Pasture & Mixed Grasses & $0-10 \%$ & Utility & Completely Destroyed & No dig & Proximity To Existing Utility & No dig & $\begin{array}{l}10 \text { North delineation test of } 72-5 \text { S. Half meter west of } \\
\text { transmission pole. }\end{array}$ & & & & & \\
\hline 12/5/19 & ST-191205-191-SS & 639068 & 3695062 & Pasture & Mixed Grasses, Woodland & $0-10 \%$ & Grading & 51-75\% & Dig & Sterile Subsoil & Negative & $20 \mathrm{~m}$ north delineation. Along fence line and $15 \mathrm{~m}$ SE of road. & 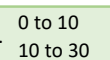 & $\begin{array}{l}\text { dark brown } \\
\text { red }\end{array}$ & $\begin{array}{l}\text { Silty Clay Loam } \\
\text { Clay }\end{array}$ & 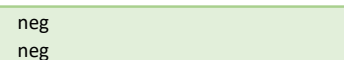 & \\
\hline
\end{tabular}




\section{APPENDIX C: HISTORICAL AND ARCHIVAL RESEARCH}


358

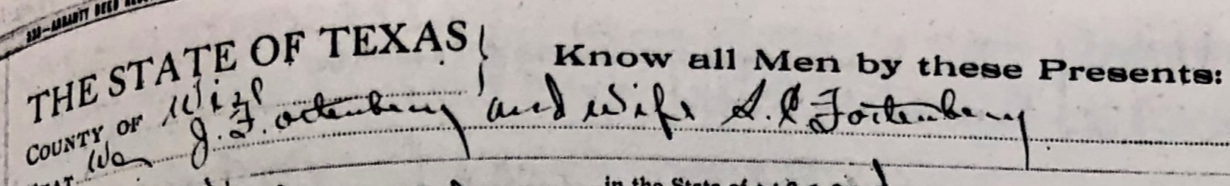

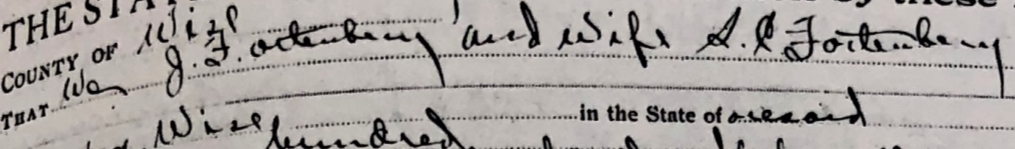

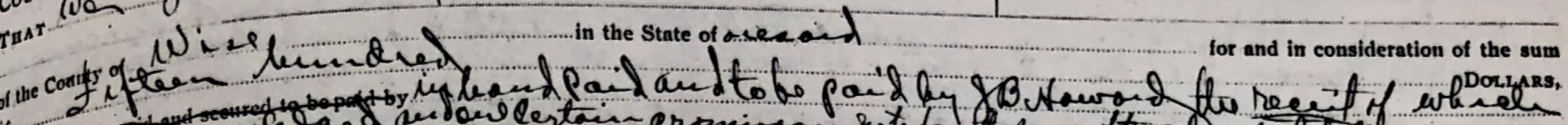

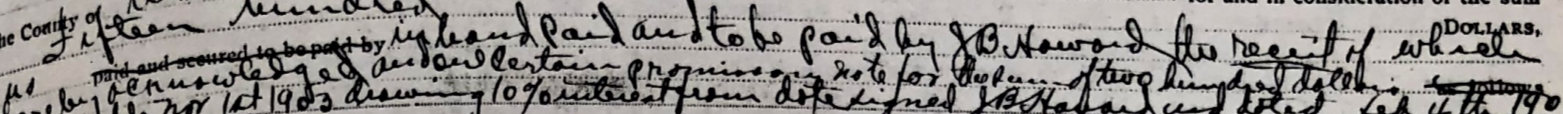

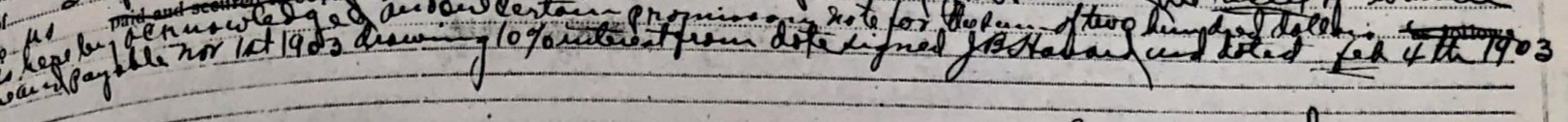

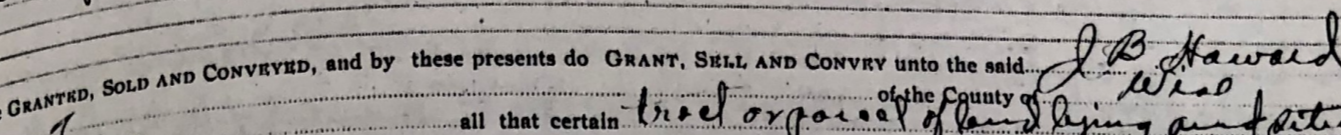
Into

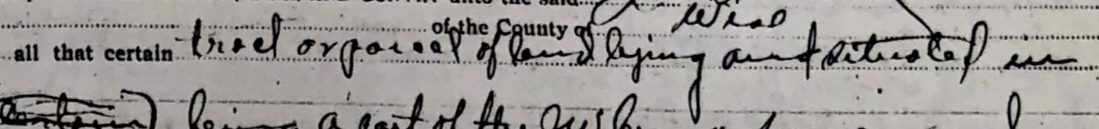

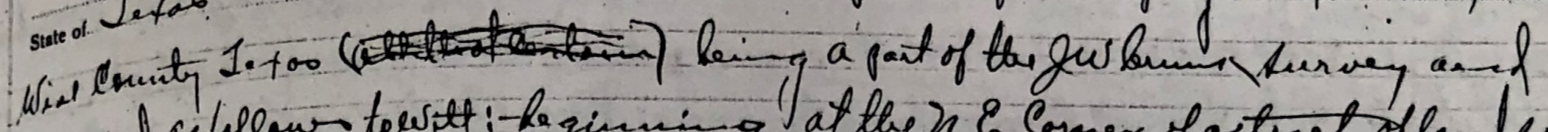

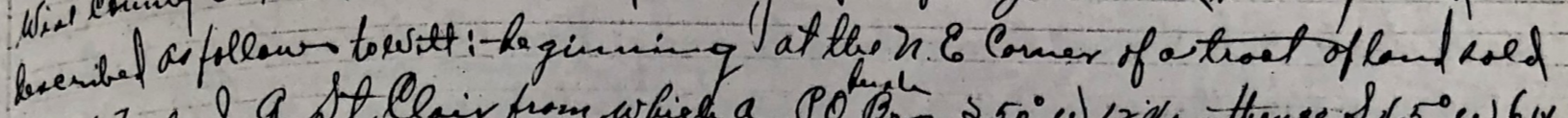

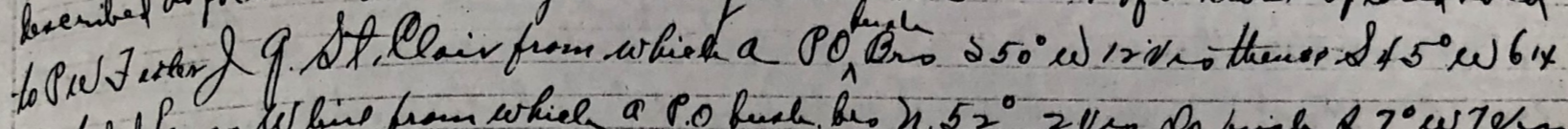

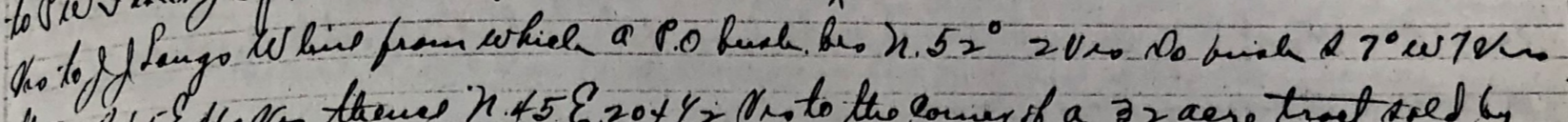

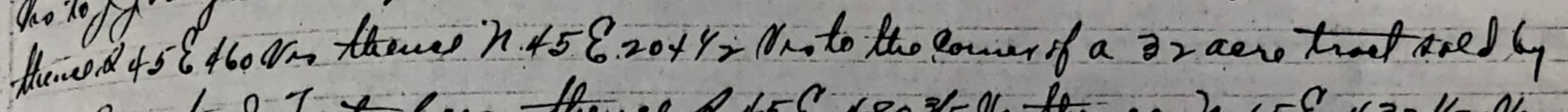

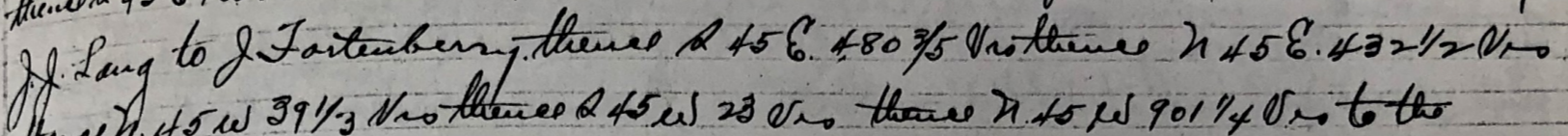

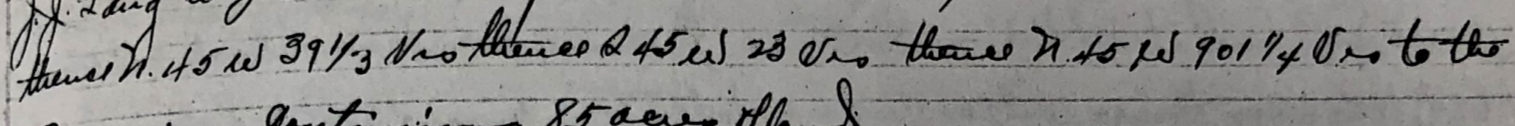
Beginning entraining 85 acer of lond

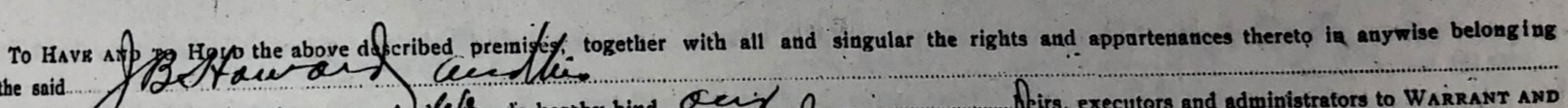

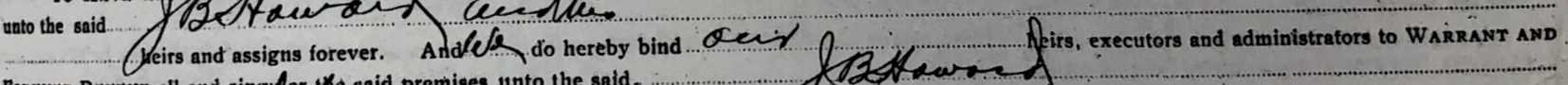
Forever DEFend all and sing y ar yes said premises unto the said.

same or any part thereof .....

heirs ad assigns, against every person whomsoever lawfully claiming or to claim the

But it is expressly agreed and stipulated that the Vendor's Lien is retained against the above de scribed property, premises and improvements, until the

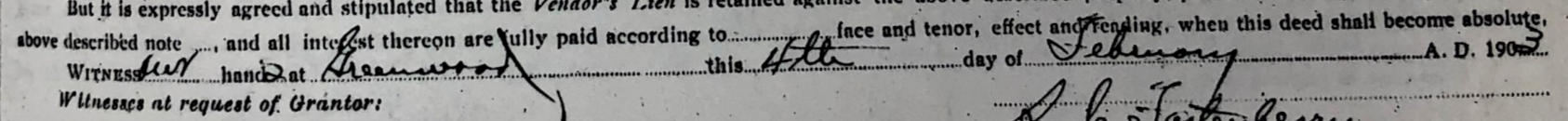

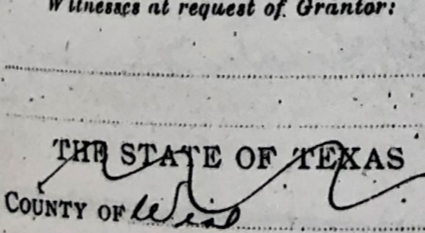

\}

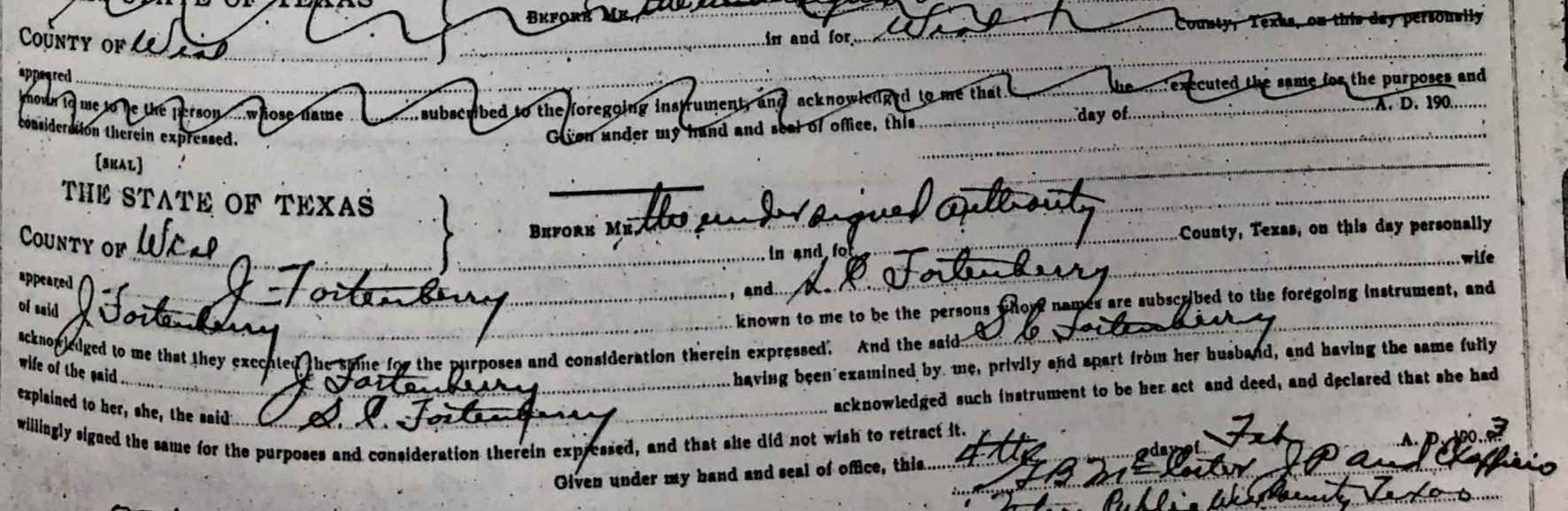

explained to her, the, the said.

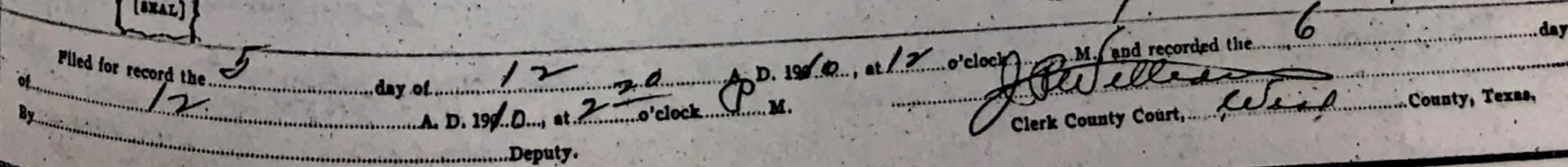




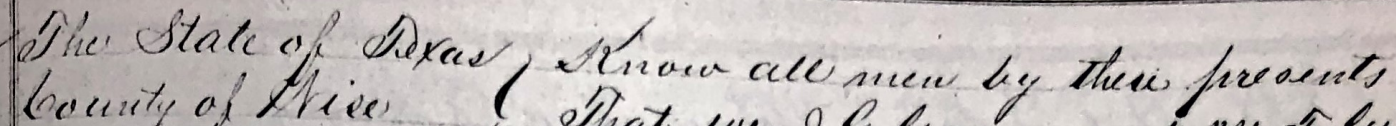

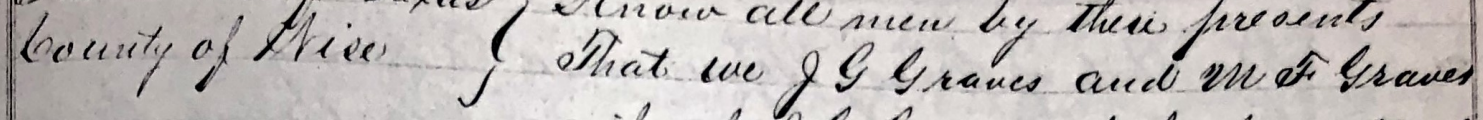
wife of $\&$ Grance of the bacuts of Lhise in the State afaresaid for and in cansideration of the sum of Sine hendred Dallars to eer in harderfiaid

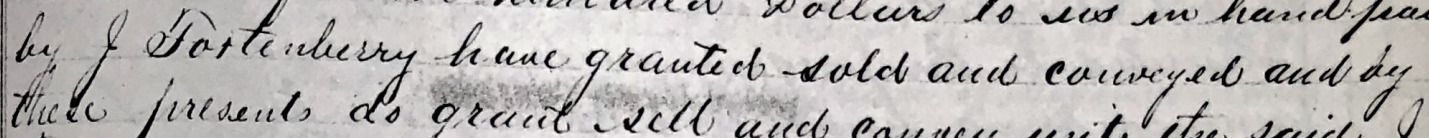
thice juesend do grand all and conney renits etre said Storterkerry of ith Gacnity of thise in the State of Sexas. all that certain tract or fearcel of land lying and sit.

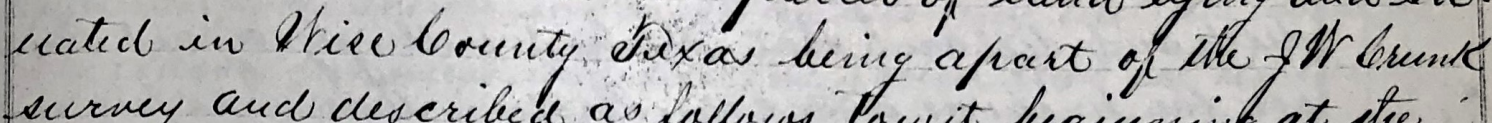

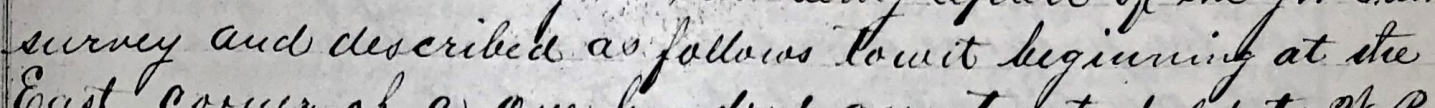

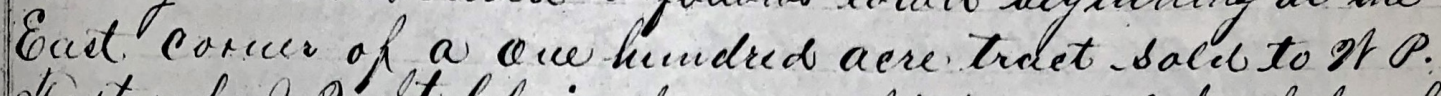

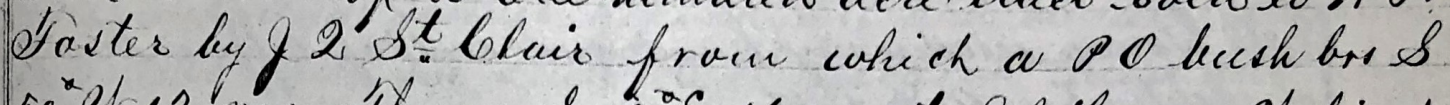

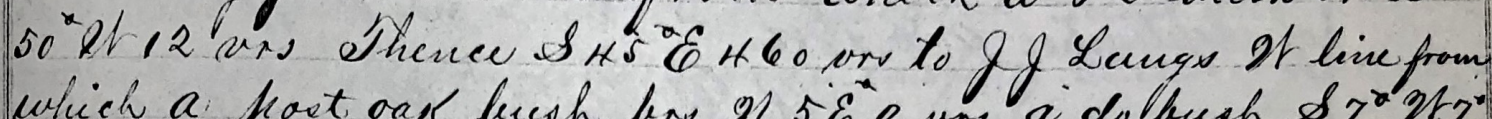

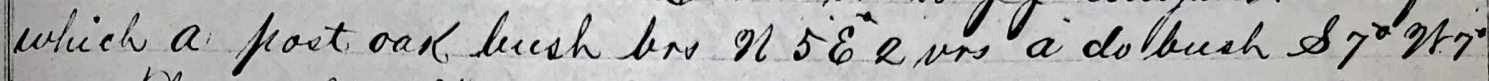

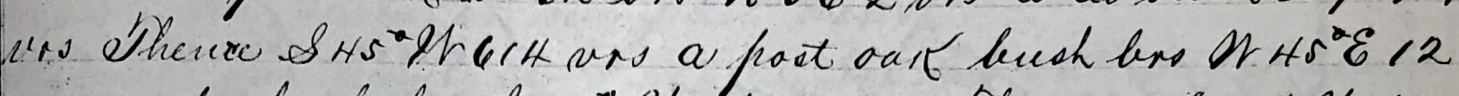

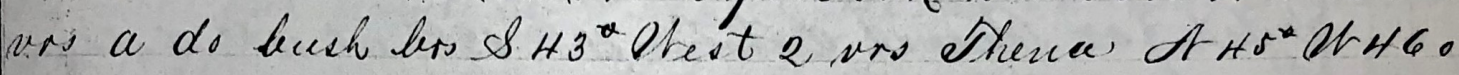

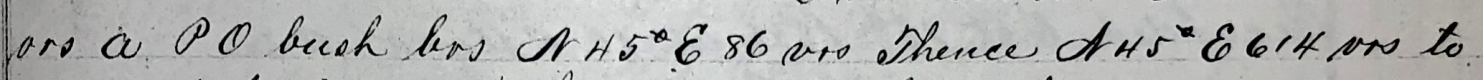
felace of hequining 20 hane and to hold the above described jirmenseo togither with all and Brigular the rights and afu purtenancel ihereti in any revies belanging unto the eard

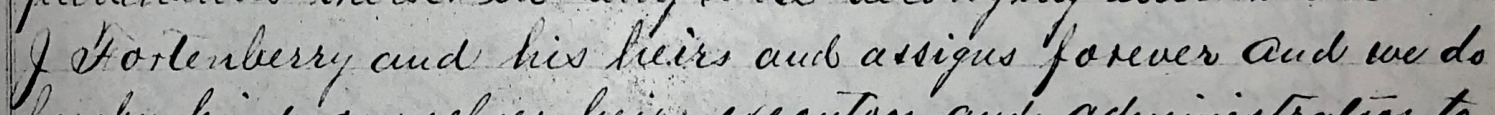

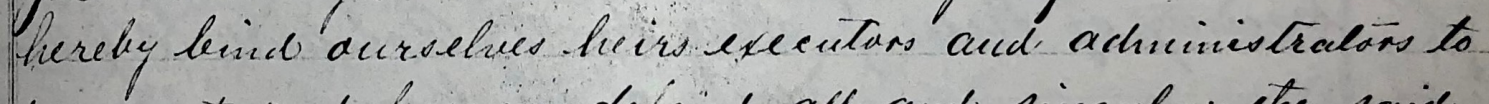
prarrant and forcuer defeind all and singular the said prenciser ento the said \& Artenverry and his heirs and

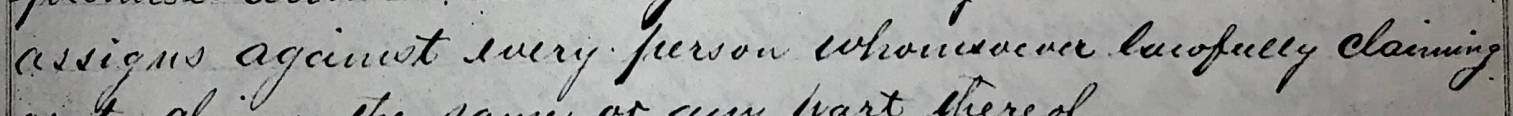
as to claim che same or any part itere of

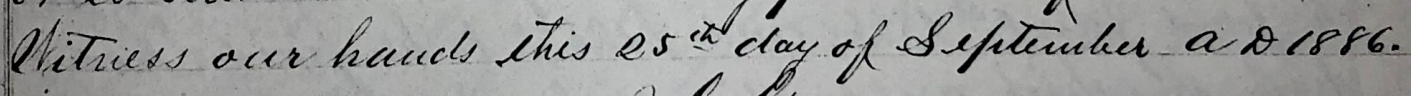

Q Graves

on Sraves

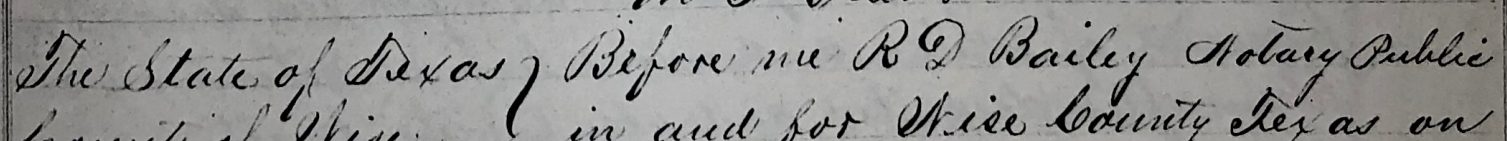
Connily of thice $I$ in and for Otries bannty tes as an litis day prevonally afifuared of errave

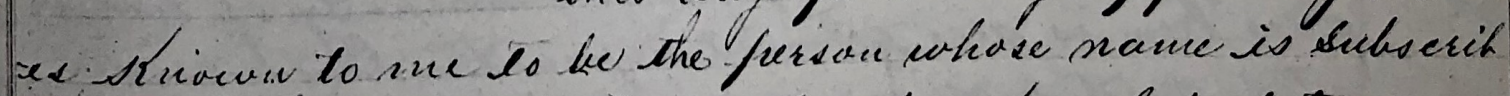
ed to the foregoning instrument and acehovolediged to me ihat he executed ithe sane for ine furfives and consi deration theresic exferessed.

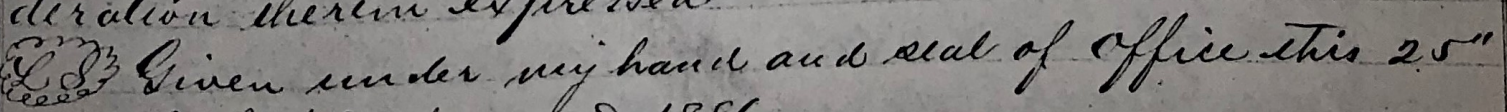
daiy of Sefincher a 81886 .

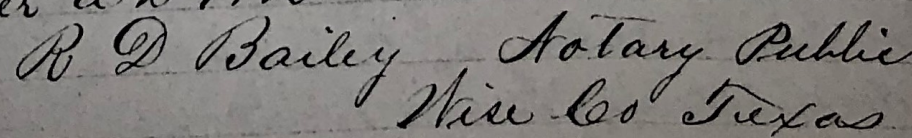




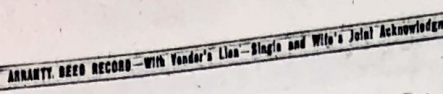

THE STATE OF TEXAS Know all Men by these Presents:

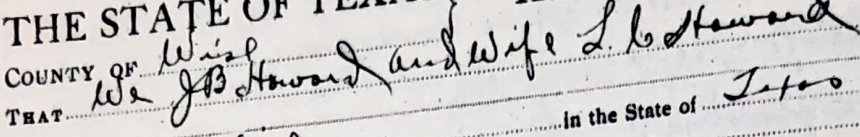

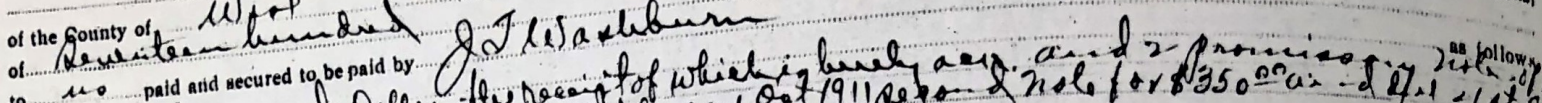

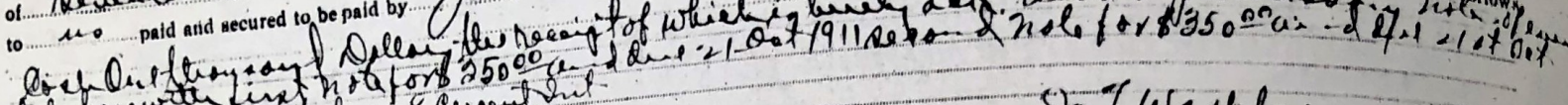

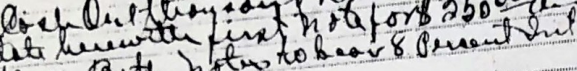

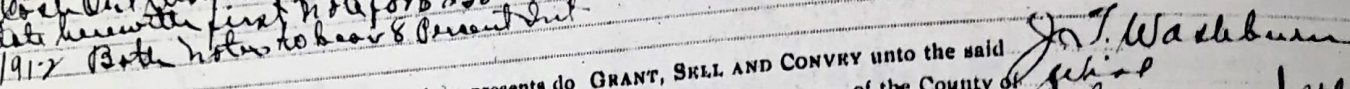

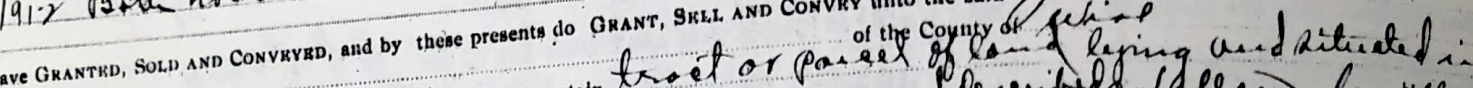

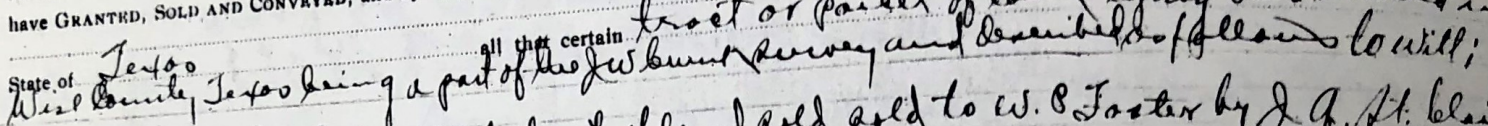

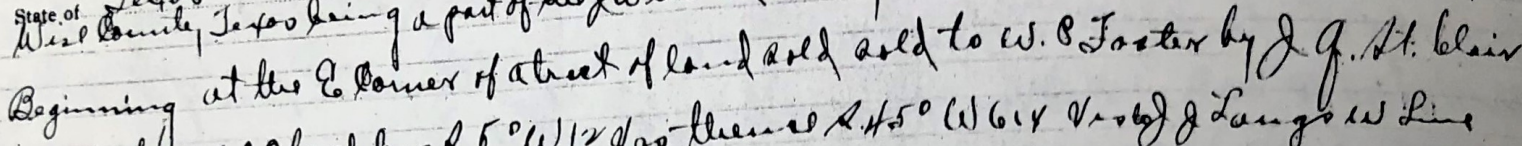

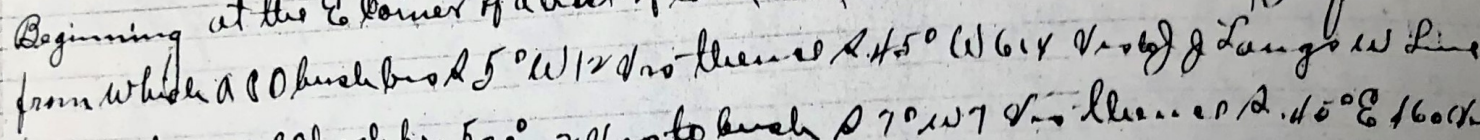

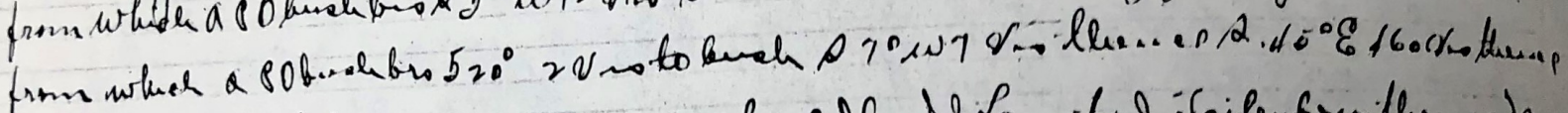

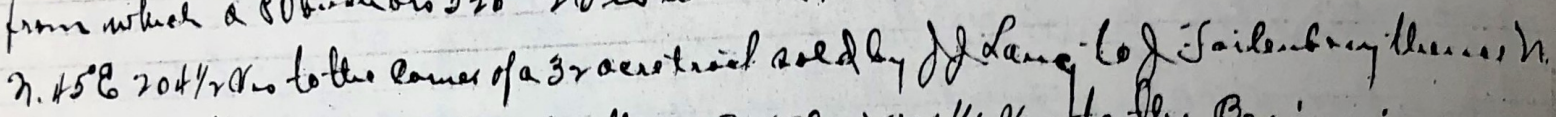

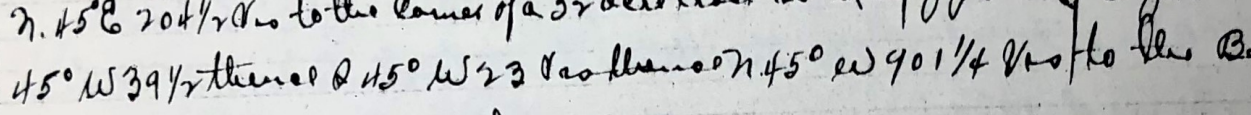
Coutaning 80 aceres of lach

To HAVR AND pO Ept.R. the ahpve described prenises, together with all and singular the rights and appurtenances thereto in anyivise belouging unto the said heis and assigns forever. Andele do hereby by

heirs and assigms, against every persan whomsoever lawfully claiming or to clain the same or any part thereof

But it is expressly agreed and stipulated that the Vendor's Lien is reto/ped against the above described property, premises and improvements, untll the

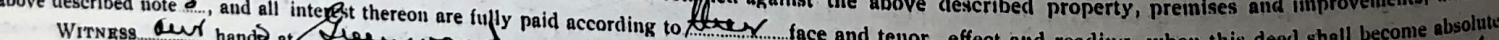

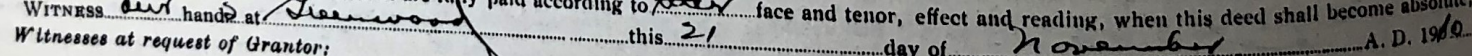

\section{Petranard}

THE STATE OF TEXAS

Countr of Wial appeared. conin to me to be the person........................ consideration therein exper... [szaL]

THE STATE OF TEXAS

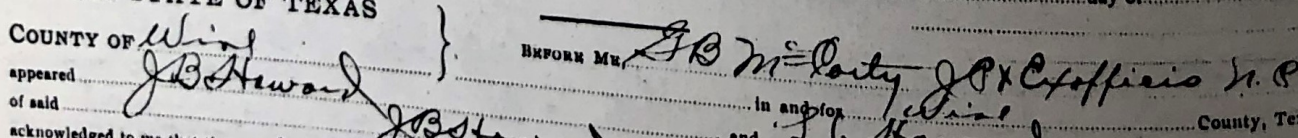

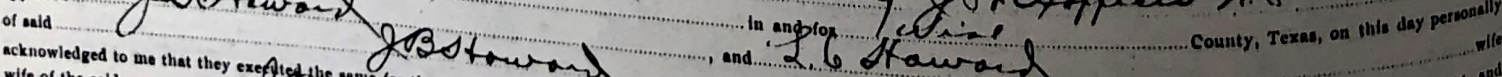

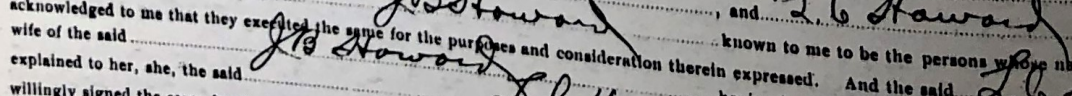

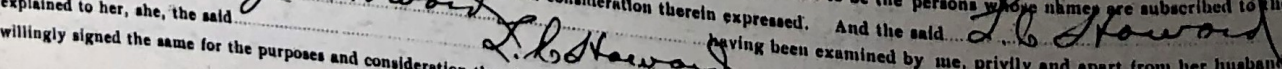

[anat] ] Given under my the did not wish to retract it.

Filed tor record ghe


William Fortenberry brought his family to Tex. from Sharp Co. Ark. in I858. In this gexpix group there were other members of the family, cousins ETC. $\mathrm{T}_{\mathrm{h}}$ e main idea in moving to Tex. Was to enter the cow business. $T_{h}$ eir first stop in Tex. was int he Filot $P_{0}$ int area. This stop was made becaude other members in the family had come before and settled here. $T_{h}$ ey remained in the $P_{\text {i lot }}$ Point area for one winter and then eame west to thell. E. corner of Wise co. and yust west of the Denton co. L. e. This area is in the corner of Wise, Cooke and Denton counties.

A nice home was built on the high hill in NE. Wise co.. The present owner of this property is James Fortenberry. They dug a cellar and dug a well. $T_{h}$ e remains of the old cellar and well are visable today. 0 the high hill was the logical place to build.

At this time the red man was the main concern. $T_{h}$ e site made a good observation point. There is a rose bush in the front yard that was planted before the Gicil War and blooms each spring. This rare attraction really brings in the tourists each year.

In oct.I858 a member of the family was killed by the $I_{n}$ dians. about a mile south of the home place. The state errected a marker a few years ago in honer of this brave citizen about $3 / 4$ mile south east of where the loss of life occured. This cousin was Severe $F$ rtenberry, and the remains are in the Gregory or Pollard Cemetery about 2 miles from the marker on Hi way 5I.

In early I87I the state closed in on the Fortenberry family and told them they would have to move west. There was not ever any homesteading in this area. T\&hey were told that they would have to go west of Jacksboro. The answer was a very ephäIEXXDX emphatic no. It at the rate of 3.50 per acre.

At this time the Chisholm trail was in full operation. Sloan the oldest boy was eight years of age when they came fron Ark. He made a real hand on the trail and went up eight times.

In 1877 Sloan was married to Kate Moore. He could see his way because he had a cattle business in full operation. The young couple met at a house warming. The dance was most gay and some unknown out of community young fen were pront. The best dancer in the group turned out to be Sam Bass. S me of my moftchisd hod memories was hearing granny tell about dancing with Sam. Hel lost his life by gunfire a sort time later at Round. Rock, Tex。

A short time before the party the Fortenberry- Family had errected a log cabin about two miles east of the first home site. The $I_{n}$ dians had been driven into $I_{n}$ dian Territory. They moved to the creek due to an abundance of wood and water. There was more game and that was a factor in more being on the table.

The log cabin was very fine and well furnished. An item that was in the house was an expensive Seth Thomas clock. This clock is in the Henry and Catherine $\mathrm{W}_{0} \mathrm{H}_{0}$ me and I can hear it ticking as I write this information. My father was born in the cabin along with three brothers. Fverett was the second son being born in I882. He followed the path of his father and was in the cow business at an early age.

In I900 the family had grown and prospered and theybegan plans for a very modern home, a two story victorian. The present home was coppleted in I90I five miles north of Slidell on the north bank of Whites Creek. There was no public road to the structure at the time but as automobiles came a road was run by the house.

The contractor was thd Tom Walden and was the best available at the time. It has five rooms down stairs a three bed rooms above and one is a double. The materials in the house are all cypress and has beaded walls and ceilings. The lumber cost 3 cents per foot and the entire cost. $\$ 3500.00$. Have heard the family say the head carpenter made? I.50 a day.

Kate Fortenberry .lived in this house until 1943. After the death of grand $\mathrm{Pa}$. she operated the ranch. S/he and grand pa laid the foundation for the largest Pure breed short horn cattle herd in the state of tex. The business has been carried on by the sons and grandchildren to the present. In the past years a pure breed hereford imex line has been added.

In the fall of I973 $J_{0} h n$ C. White Commissioner of Agriculture, Tex. presented us with a plaque that honored the present owners Mr Mrs Henry Fortenbbery for having been on a farm and operating it for a I00 years in the same family. $T_{h}$ ere are very
few such home steads in the stste

We have kept the home in repair and live there much of the time ano have a nice herd of catile there. and on other property.

Vore infornation on this subject is available in the Denton, Co. History. P.S. More corments about house, Parlor has double base boards, Fortenberry

Ceiling design of cypress house, Parlor has double base boards, carved window facings. fire place with carved mantel. Original hardooring. Ifving room has big liximox fire place with carved mantel. Original hardware on alldoors and windows add charm to the house. "fhe front door is high liphted with stained glass nnd carvings. A large screen porch surrónds much of the lower floor. I9OI, date house was built, is shown at the top of the chimney and lighning rods reach for the sky. This house sits behind a
white pickett fence 


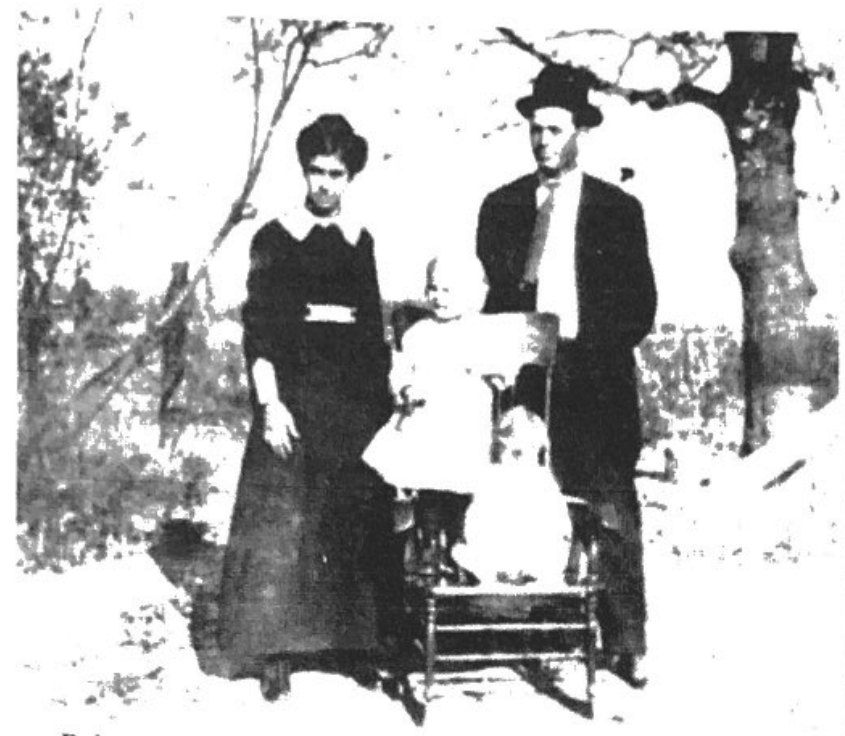

Robert and Oma Howard, Eva Marie, and John Fulton in the front yard of the old Howard homeplace on farm near Greenwood.

Laura married John Moore; Lum married Nellie Fullingham; Nellie June married Walter Derryberry. Mary Jane's parents, Hulin Fulton and Margaret Hill, were born in Ireland.

Joseph C. Chance died on February 27, 1909. Mary Jane died August 28, 1913. Both are buried in Henrietta, Texas.

John and Lillie Howard are buried at Greenwood. Lillie lived to be ninety years of age. She passed away November 28,1948 .

The following is an excerpt from a poem written by Ernest after his father died.

"'His life to us was a noble lesson taught, May it reflect then for more than aught.

For the life he lived 'twas his desire,

Would help his loved to look up higher -

The noble spirit he possessed,

Went hand in hand with him to rest.

Remember then children and bear in mind.

A mother's love only will excel father's - you'll find.'

Compiled by Eva Marie (Howard) Atkins

\section{JOE BARNETT HOWARD}

Joe Barnett Howard was born March 26, 1890. His parents were John Barnett Howard and Lillie Caroline Chance. They came to Texas from Monett, Missouri. After their marriage they lived in the Brumlow community. Their home was at the foot of "Tater Hill," some miles north of Decatur and west of the town of Greenwood. Joe was the fourth child of ten children born to John and Lillie, most of them being born in Brumlow.

John Barnett and Lillie bought a farm two miles west of Greenwood. This farm was later owned by Joe and Chloe Howard.

Joe attended the Greenwood Male and Female College. He later taught school in Seminole County, Okla-

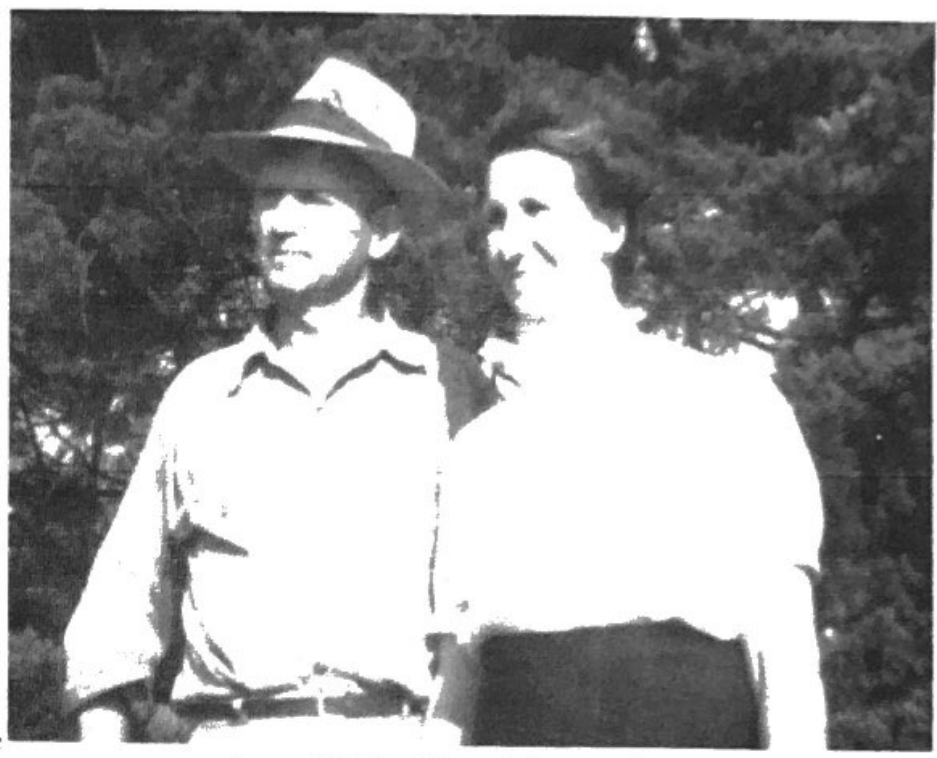

Joe and Chloe Howard about 1943.

homa. He later returned to Greenwood, Texas and married Chloe Edith Koiner of Krum, Texas, in Denton County on October 26, 1917.

The town of Greenwood was a thriving place. It had several grocery stores, a barbershop, two drug stores, and a cotton gin.

Joe worked hard to build up the land, by rotating crops and growing peas and fertilizing with barnyard manure. He had a big fruit orchard and vegetable garden.

The first child born to Joe and Chloe Howard was Wilema. She was born September 11, 1918. She married Joe England on December 24, 1941. They had two children. Their names are Robert Thurmond and Terry Don.

Their next child, Charles Warren was born November 8, 1920. He married Emily Jones of Fernandina Beach, Florida. They had two children and their names are Charles Jr. and David.

Joe and Chloe Howard's third child, Lillie Mae, was born January 24, 1924. She married J.E. Haynes. Their

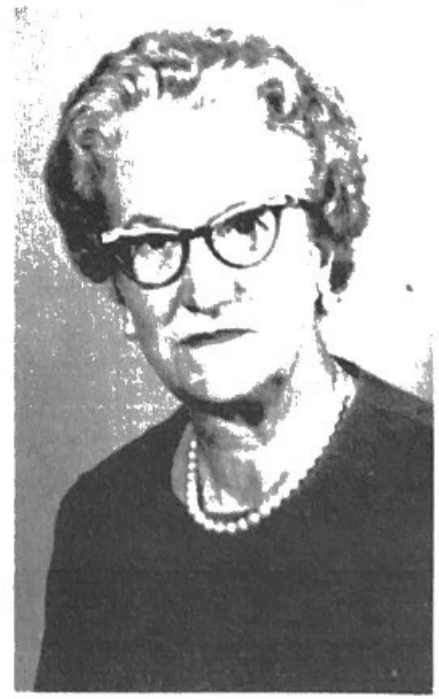

Mrs. Chloe Howard 
Newspapers

by oflancestry

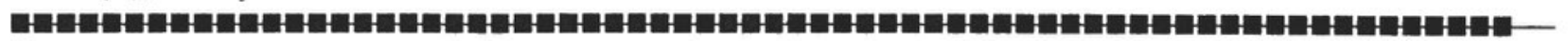

घ

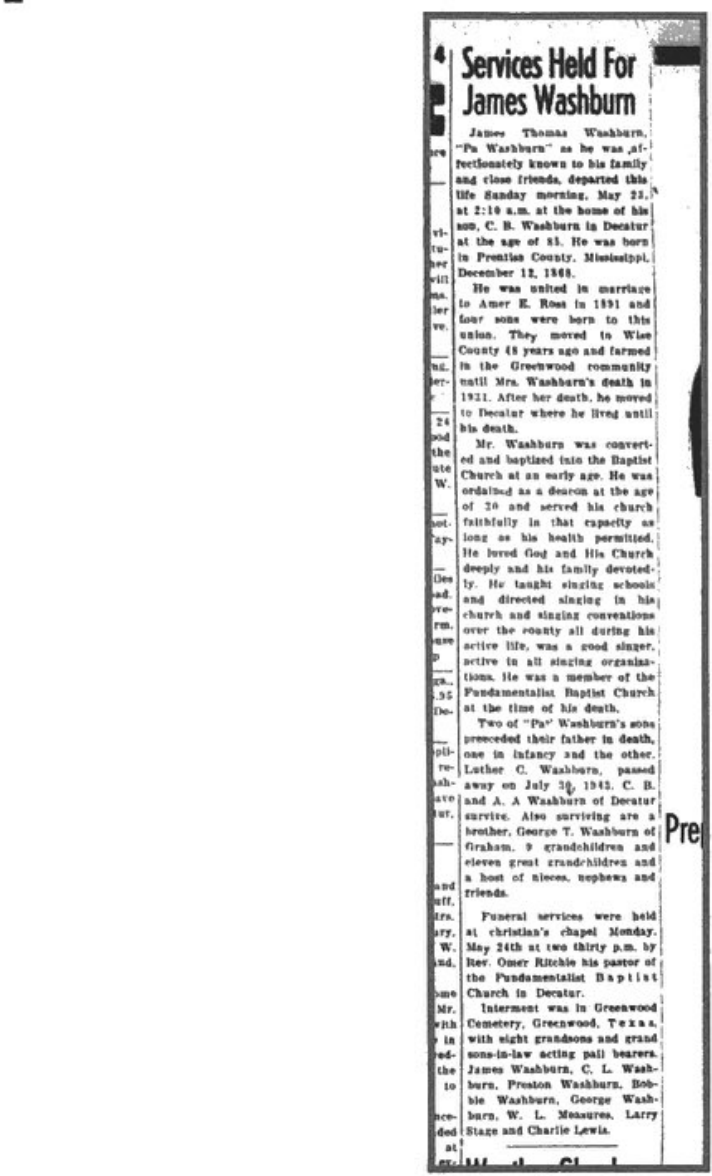

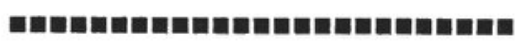

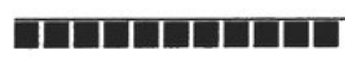

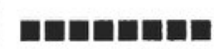

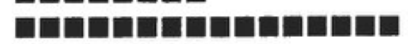


Figure Redacted Due to Site Sensitive Data 
Figure Redacted Due to Site Sensitive Data 
Figure Redacted Due to Site Sensitive Data 
Figure Redacted Due to Site Sensitive Data 
Figure Redacted Due to Site Sensitive Data 
Figure Redacted Due to Site Sensitive Data 
Figure Redacted Due to Site Sensitive Data 
Figure Redacted Due to Site Sensitive Data 
Figure Redacted Due to Site Sensitive Data 
Figure Redacted Due to Site Sensitive Data 
Figure Redacted Due to Site Sensitive Data 
Figure Redacted Due to Site Sensitive Data 
Figure Redacted Due to Site Sensitive Data 
Figure Redacted Due to Site Sensitive Data 


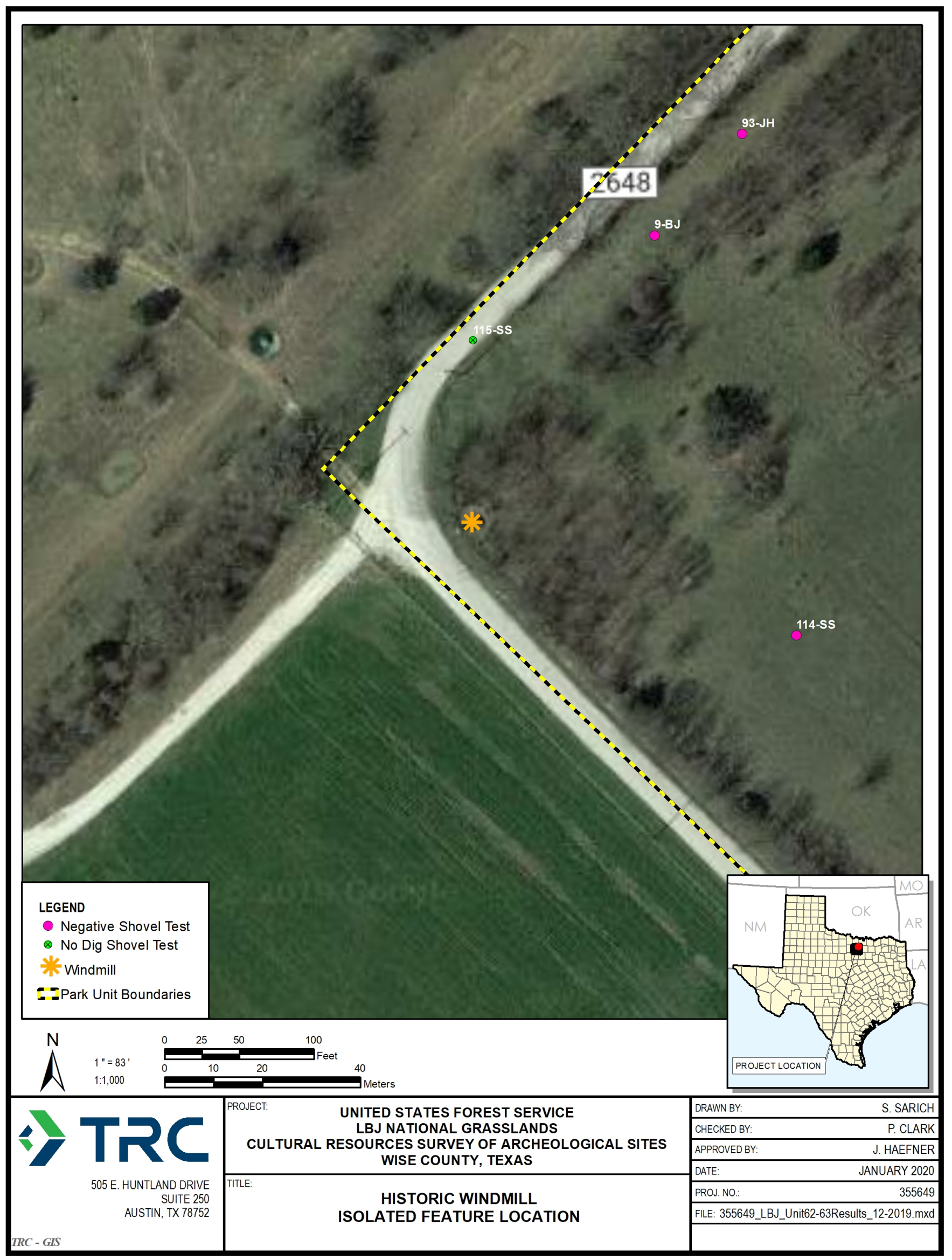

